\title{
The role of dinucleoside polyphosphates on the ocular surface and other eye structures
}

\author{
Gonzalo Carracedo ${ }^{\mathrm{a}, 1}$, Almudena Crooke ${ }^{\mathrm{b}, 1}$, Ana Guzman-Aranguez ${ }^{\mathrm{b}, 1}$,

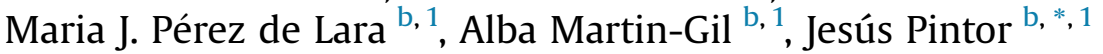 \\ a Department of Optics II (Optometry and Vision), Faculty of Optics and Optometry, Universidad Complutense de Madrid, Madrid, Spain \\ ${ }^{\mathrm{b}}$ Department of Biochemistry and Molecular Biology IV, Faculty of Optics and Optometry, Universidad Complutense de Madrid, Madrid, Spain
}

\section{A R T I C L E I N F O}

\section{Article history:}

Received 28 February 2016

Received in revised form

30 June 2016

Accepted 5 July 2016

Available online $\mathrm{xxx}$

\section{Keywords:}

Dinucleotides

Purinergic receptors

Diadenosine tetraphosphate

Diquafosol

\begin{abstract}
A B S T R A C T
Dinucleoside polyphosphates comprises a group of dinucleotides formed by two nucleosides linked by a variable number of phosphates, abbreviated $\mathrm{NpnN}$ (where $\mathrm{n}$ represents the number of phosphates). These compounds are naturally occurring substances present in tears, aqueous humour and in the retina. As the consequence of their presence, these dinucleotides contribute to many ocular physiological processes. On the ocular surface, dinucleoside polyphosphates can stimulate tear secretion, mucin release from goblet cells and they help epithelial wound healing by accelerating cell migration rate. These dinucleotides can also stimulate the presence of proteins known to protect the ocular surface against microorganisms, such as lysozyme and lactoferrin. One of the latest discoveries is the ability of some dinucleotides to facilitate the paracellular way on the cornea, therefore allowing the delivery of compounds, such as antiglaucomatous ones, more easily within the eye. The compound $\mathrm{Ap}_{4} \mathrm{~A}$ has been described being abnormally elevated in patient's tears suffering of dry eye, Sjogren syndrome, congenital aniridia, or after refractive surgery, suggesting this molecule as biomarker for dry eye condition. At the intraocular level, some diadenosine polyphosphates are abnormally elevated in glaucoma patients, and this can be related to the stimulation of a $\mathrm{P}_{2} \mathrm{Y}_{2}$ receptor that increases the chloride efflux and water movement in the ciliary epithelium. In the retina, the dinucleotide $\mathrm{dCp}_{4} \mathrm{U}$, has been proven to be useful to help in the recovery of retinal detachments. Altogether, dinucleoside polyphosphates are a group of compounds which present relevant physiological actions but which also can perform promising therapeutic benefits.
\end{abstract}

() 2016 Elsevier Ltd. All rights reserved.

\section{Contents}

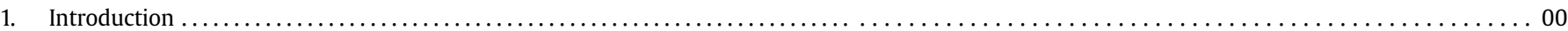

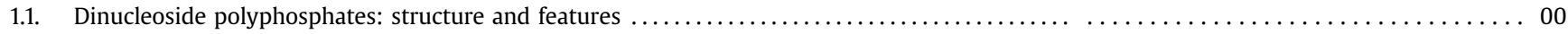

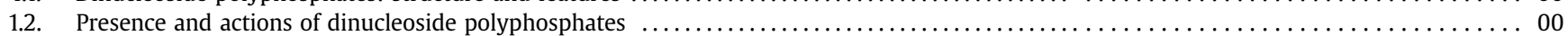

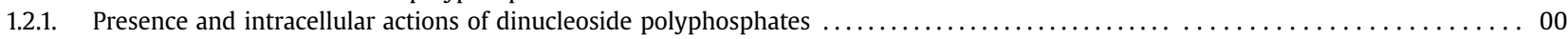

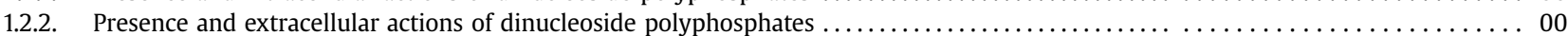

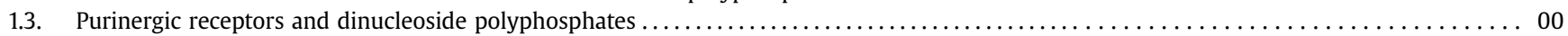

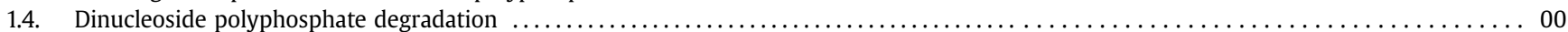

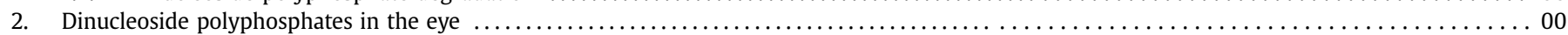

\footnotetext{
* Corresponding author. Dep. Biochemistry and Molecular Biology IV, Faculty of Optics and Optometry, Universidad Complutense de Madrid, C/Arcos del Jalon 118, 28037 Madrid, Spain.

E-mail address: jpintor@ucm.es (J. Pintor).

1 Percentage of work contributed by each author in the production of the manuscript is as follows: Gonzalo Carracedo 35\%; Almudena Crooke 10\%; Ana Guzman-Aranguez 10\%; M.J. Perez de Lara 10\%; Alba Martin-Gil 10\%; Jesus Pintor $25 \%$.
}

http://dx.doi.org/10.1016/j.preteyeres.2016.07.001

1350-9462/৫ 2016 Elsevier Ltd. All rights reserved. 


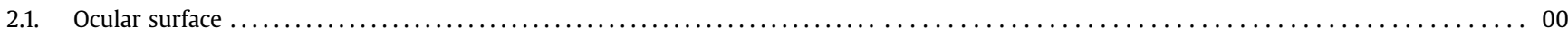

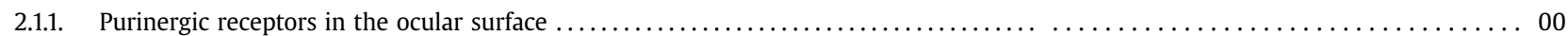

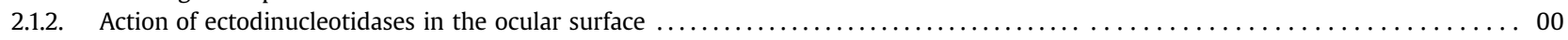

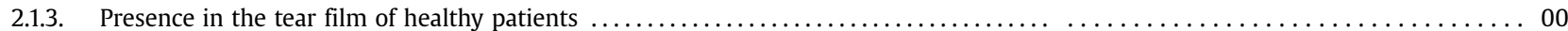

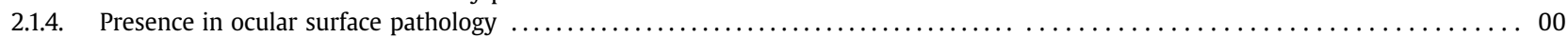

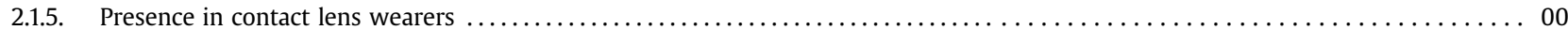

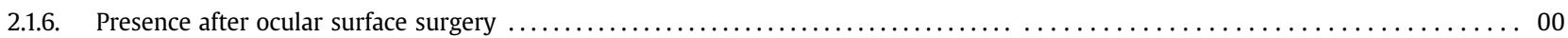

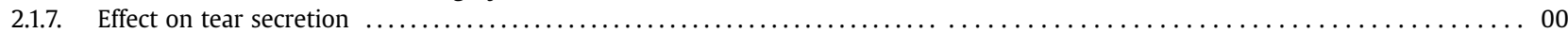

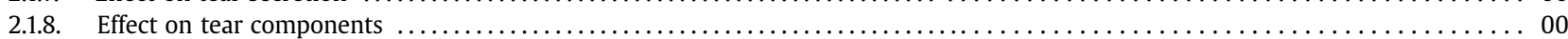

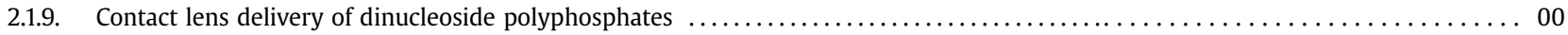

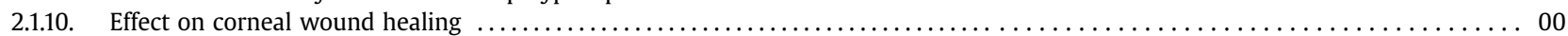

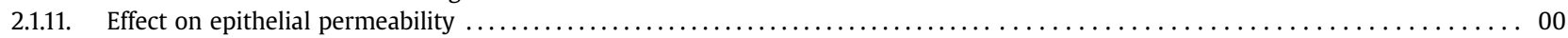

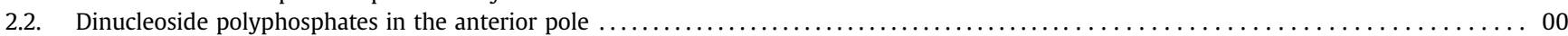

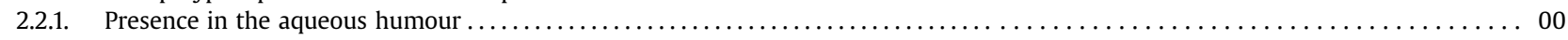

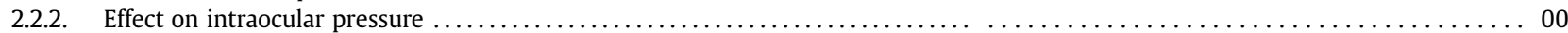

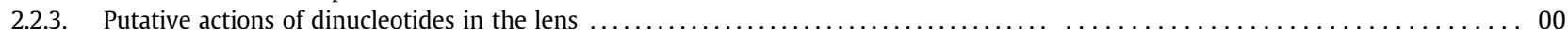

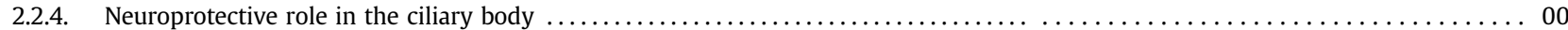

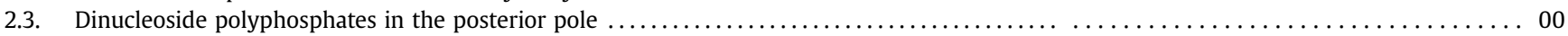

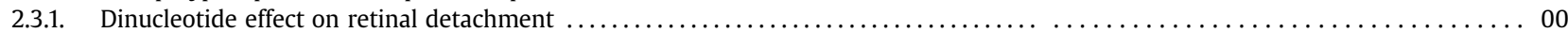

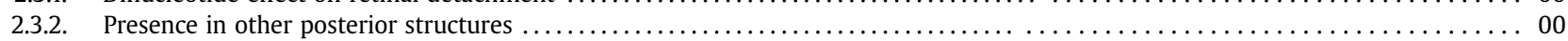

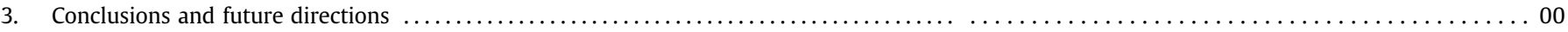

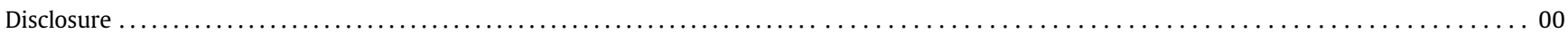

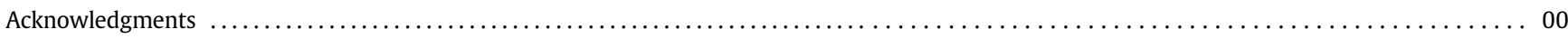

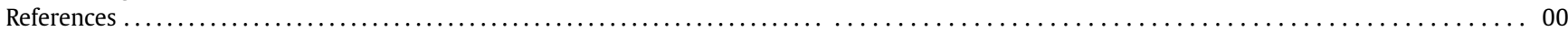

\section{Introduction}

\subsection{Dinucleoside polyphosphates: structure and features}

Dinucleoside polyphosphates are a family of dinucleotides related to others such as nicotinamide adenine dinucleotides (NAD and NADP), but slightly different in their structure. Dinucleoside polyphosphates comprise all those dinucleotides formed by two nucleosides bridged by a variable number of phosphates. The two nucleosides moiety can be formed by ribose which may present the same or different bases, either purines or pyrimidines (Fig. 1). Although in theory the possibilities of dinucleotides are enormous, simply by combining the nitrogenised bases and the phosphate length, there are only a few which have been recognised as naturally occurring dinucleoside polyphosphates, nonetheless, other dinucleoside polyphosphates have been synthesised either enzymatically or chemically (Guranowski et al., 1995; Mizuno and Sasaki, 1965; Ortiz et al., 1993). Dinucleoside polyphosphates can be named in different ways, for instance, $\alpha, \omega$ dinucleoside polyphosphates, dinucleoside $5^{\prime}, 5^{\prime \prime \prime}-P^{1}, P^{n}$ polyphosphates or $N p_{n} N$. The latter is the most common one in which " $\mathrm{N}$ " is substituted by the bases (A, G, U, for example) and " $n$ " by the number of phosphates.

Dinucleoside polyphosphates found in biological systems are those formed by two adenosines, which are termed diadenosine polyphosphates, $\mathrm{Ap}_{\mathrm{n}} \mathrm{A}$, the ones formed by guanosines, diguanosine polyphosphates, $G p_{n} G$, or a combination of both, one moiety with adenosine and the other with guanosine $\left(\mathrm{Gp}_{n} \mathrm{~A}\right)$. Concerning the phosphate length linking both nucleosides, this can vary from two to seven, although the most common are those dinucleotides with 3-5 phosphates. Common, naturally occurring dinucleoside polyphosphates, according to the number of phosphates, are $\mathrm{Ap}_{5} \mathrm{~A}$ or $\mathrm{Gp}_{4} \mathrm{G}$.

Synthetic dinucleoside polyphosphates are relevant since they depict remarkable actions on ocular physiology (Guzman-Aranguez et al., 2007, 2011). Among these the ones with uridine, diuridine polyphosphates (like $\mathrm{Up}_{4} \mathrm{U} A K A$ diquafosol), with deoxycytidine and uridine $\left(\mathrm{dCp}_{4} \mathrm{U}\right.$, also termed denufosol), or those with hypoxanthine, diinosine polyphosphates $\left(\operatorname{Ip}_{n} \mathrm{I}\right)$, have demonstrated<smiles>Nc1ncnc2c1ncn2[C@@H]1O[C@H](COP(=O)(O)OP(=O)(O)OP(=O)(O)OP(=O)(O)OC[C@H]2O[C@@H](n3cnc4c(N)ncnc43)[C@H](O)[C@@H]2O)[C@@H](O)[C@@H]1O</smiles><smiles>O=c1ccn([C@@H]2O[C@H](COP(=O)(O)OP(=O)(O)OP(=O)(O)OP(=O)(O)OC[C@H]3O[C@@H](n4ccc(=O)[nH]c4=O)[C@H](O)[C@@H]3O)[C@@H](O)[C@H]2O)c(=O)[nH]1</smiles><smiles>Nc1ccn([C@@H]2O[C@H](COP(=O)(O)OP(=O)(O)OP(=O)(O)OP(=O)(O)OC[C@H]3O[C@@H](n4ccc(=O)[nH]c4=O)[C@H](O)[C@@H]3O)C[C@H]2O)c(=O)n1</smiles>

Fig. 1. Chemical structure of dinucleoside polyphosphates. The top panel shows the molecular structure of diadenosine tetraphosphate $\left(\mathrm{Ap}_{4} \mathrm{~A}\right)$. The middle and bottom figures shows two synthetic dinucleoside polyphosphates relevant in ocular physiological processes, diuridine polyphosphate ( $\mathrm{Up}_{4} \mathrm{U}$ in the middle) and uridine deoxycytidine tetraphosphate $\left(\mathrm{dCp}_{4} \mathrm{U}\right.$, below). 
interesting therapeutic properties in the eye as it will later be described (Fujihara et al., 2001; Guzman-Aranguez et al., 2012).

The history of dinucleoside polyphosphates started far away from the future physiological and pharmacological applications found in the eye. Indeed, the first news on these molecules occurred in the 1960's. Dinucleoside polyphosphates were discovered in the eggs of brine shrimps, mostly diguanosine polyphosphates (Finamore and Warner, 1963; Warner, 1964). These dinucleotides are the basis for the development of the eggs into proper shrimps since they will be used for DNA synthesis.

It was not until a few years later when it was possible to identify a biochemical reaction showing the synthesis of a dinucleoside polyphosphate. Scientists, when investigating the reaction between aminoacids and their corresponding tRNAs during the protein synthesis process discovered the presence of some diadenosine polyphosphates (Randerath et al., 1966; Zamecnik et al., 1966). Over the following years, most of the efforts were dedicated to describing their structural and chemical properties, mainly by spectrometric methods (Bush and Tinoco, 1967; Cheng, 1968; Warshaw and Tinoco, 1965). Changes in the molecules present were also studied when environmental properties (Lee et al., 1979) such as temperature or pH was modified (Chan and Nelson, 1969; Davis and Tinoco, 1968; Glaubiger et al., 1968; Hruska and Danyluk, 1968; Ikehara et al., 1970; Rabczenko and Shugar, 1971; Ts'o et al., 1969). The structural changes are especially relevant when the $\mathrm{pH}$ medium is altered. The structure of a $\mathrm{Np}_{\mathrm{n}} \mathrm{N}$, for example, $\mathrm{Ap}_{4} \mathrm{~A}$, under physiological $\mathrm{pH}$ condition $(\mathrm{pH} \approx 7$ ), depicts a stacked conformation in which the adenine rings are piled up, this being possible due to the phosphate chain folding. This is caused by the negatively charged phosphate groups and the partially positively charged adenine rings and the consequent electrostatic interactions. A different panorama is observed when the $\mathrm{pH}$ lowers $(\mathrm{pH} \approx 4)$. Under this condition the phosphates are folded but the adenine rings are pointing to opposite directions. The maximal open possible conformation is reached at a $\mathrm{pH}$ below 3 . Under this condition the protonation of the phosphates occurs and the interactions among the adenines and phosphates do not exist (Guzman-Aranguez et al., 2011).

The conformational changes observed at different $\mathrm{pH}$, may explain why these dinucleotides can interact with different purinergic receptors, mainly when in some environmental conditions, such as acidic synapses (glutamatergic) the conditions can be far from neutral conditions (Gualix et al., 2003).

Concerning temperature, it seems that dinucleoside polyphosphates at low temperatures present their bases in a stacking conformation being so close to each other that there is no room for water between them. On the contrary, when temperature is high, even at denaturing conditions (above $40{ }^{\circ} \mathrm{C}$ ), the bases are not stacked and they do not interact with each other and therefore can interact with the solvent and other molecules. In this case, the only limitation of the aromatic bases would be their covalent bonds to the respective riboses (Davis and Tinoco, 1968; Glaubiger et al., 1968).

\subsection{Presence and actions of dinucleoside polyphosphates}

\subsubsection{Presence and intracellular actions of dinucleoside polyphosphates}

It took quite a long time from the moment these dinucleotides were identified until some biochemical and physiological actions for these compounds were detected. One of the first actions was the effect of diadenosine tetraphosphate, $\mathrm{Ap}_{4} \mathrm{~A}$, on DNA polymerase triggering DNA replication (Grummt, 1978, 1979; Grummt et al., 1979). Indeed, it has been possible to correlate changes (increases) in $\mathrm{Ap}_{4} \mathrm{~A}$ concentrations during the cell cycle and specially during cell proliferation and DNA synthesis (Bambara et al., 1985). These experiments were quite controversial, although other authors could, in part, confirm the relationship between $\mathrm{Ap}_{4} \mathrm{~A}$ and DNA synthesis, it seemed that apparently the dinucleotide would prime DNA synthesis rather than activating the polymerase (Zamecnik et al., 1982). Also, some other studies suggested a close relation between the amino acid activation process and DNA replication in mammalian cells (Grummt, 1983; Rapaport et al., 1981).

Another intracellular action suggested for dinucleoside polyphosphates has been its possible role of "alarmone" (Lee et al., 1983; Varshavsky, 1983). An alarmone is a molecule that reflects and indicates a stress situation within a cell. A classical situation is that in which an elevation of temperature, apart from increasing the levels of heat shock proteins (HSPs), also produces a rise in dinucleoside polyphosphates such as $A p_{3} A, A p_{4} A, G_{4} A$ and $G_{3} A$ (Lee et al., 1983). The same dinucleotides are increased when cells are submitted to oxidative stress in a process independent from the dinucleotide synthesis by aminoacyl-tRNA synthetases.

\subsubsection{Presence and extracellular actions of dinucleoside polyphosphates}

Although the presence and actions of dinucleoside polyphosphates have been reported in several tissues as indicated (Andersson, 1989; Rapaport and Zamecnik, 1976; Ripoll et al., 1996), two sources are relevant concerning the eye physiology: the blood vessels and the nervous system.

Apart from the presence of dinucleoside polyphosphates in crustaceans as previously indicated, these molecules were found as putative active vasoactive compounds when they were discovered in platelet secretory granules (Flodgaard and Klenow, 1982; Luthje and Ogilvie, 1983). From the moment they were discovered the main interest of the scientific community was to identify those actions triggered by the dinucleotides in the blood stream. In this sense, one of the first roles was their involvement in platelet aggregation. Interestingly, the two dinucleotides contained in the platelets (in their dense granules), $A p_{3} A$ and $A p_{4} A$, depicted opposite actions; while the first was inducing platelet aggregation, the second, showed disaggregating properties (Luthje et al., 1985). Nonetheless, the existence of dinucleoside polyphosphates in the plasma and blood (Luthje and Ogilvie, 1988), also suggested an effect on vasoconstriction or/and vasodilation. When analysing the effect of the vascular tone, dinucleoside polyphosphates such as $\mathrm{Ap}_{4} \mathrm{U}$ produces a biphasic effect although the predominant one at low concentrations is vasoconstriction, infusions of this dinucleotide elicit hypotension and electrolyte retention (Flores et al., 1999; Hansen et al., 2010).

The identification of dinucleoside polyphosphates and mainly diadenosine polyphosphates in neural secretory vesicles showed the storage of these dinucleotides with classical transmitters such as noradrenalin (Rodriguez del Castillo et al., 1988). This colocalization was further extended to cholinergic and monoaminergic synaptic vesicles (Miras-Portugal et al., 1998, 1999; Pintor et al., 1992). Moreover, it was possible to demonstrate that these dinucleotides were releasable in $\mathrm{a} \mathrm{Ca}^{2+}$ dependent manner from brain synaptic terminals (Pintor et al., 1991, 1992) and also by the effect of drugs such as amphetamines (Pintor et al., 1993). The role of diadenosine polyphosphates, mainly $\mathrm{Ap}_{4} \mathrm{~A}$ and $\mathrm{Ap}_{5} \mathrm{~A}$ in the nervous system has been the modulation of the release of monoamines (Giraldez et al., 2001), glutamate (Gualix et al., 2003), or the inhibition of synaptic transmission in the hippocampus (Klishin et al., 1994). 


\subsection{Purinergic receptors and dinucleoside polyphosphates}

Extracellular actions of dinucleoside polyphosphates occurred by means of receptors on the cell surface termed P2 purinergic receptors. These types of receptors are divided into two families, the P2X ionotropic (Habermacher et al., 2015) and the P2Y metabotropic receptors (von Kugelgen and Harden, 2011).

P2X receptors are activated by nucleotides and dinucleotides which mediate the rapid and non-selective cation transients (mainly $\mathrm{Na}^{+}$and $\mathrm{Ca}^{2+}$ ) from the extracellular space (Samways et al., 2014), causing depolarization of the membrane ion channels and subsequent activation of voltage dependent calcium channels. Seven members of $\mathrm{P} 2 \mathrm{X}$ receptors in mammalians have been cloned (P2X1-P2X7) and they combined various forms of these subunits (Saul et al., 2013). Cloning of P2X receptors has revealed that all the subunits have large extracellular loop with ten cysteine residues, two transmembrane domains and short intracellular $\mathrm{C}$ and $\mathrm{N}$ terminals (Roberts et al., 2006). Three subunits are necessary to form a functional native channel, and these channels are organized as homotrimers or heterotrimers (Coddou et al., 2011).

$\mathrm{P} 2 \mathrm{Y}$ receptors are metabotropic receptors, members of the family of $G$ protein-coupled receptors containing seven hydrophobic transmembrane domains connected by three extracellular loops and three intracellular loops, with an extracellular N-terminal end and another C-terminal oriented intracellularly (Jacobson and Boeynaems, 2010). These receptors are coupled, via G proteins to others, such as phospholipase C (PLC), adenylate cyclase or to ion channels (von Kugelgen and Hoffmann, 2015). To date, the P2Y family comprises eight members ( $\mathrm{P}_{2} \mathrm{Y}_{1}, \mathrm{P}_{2} \mathrm{Y}_{2}, \mathrm{P}_{2} \mathrm{Y}_{4}, \mathrm{P}_{2} \mathrm{Y}_{6}, \mathrm{P}_{2} \mathrm{Y}_{11}$, $\mathrm{P}_{2} \mathrm{Y}_{12}, \mathrm{P}_{2} \mathrm{Y}_{13}$ and $\mathrm{P} 2 \mathrm{Y}_{14}$ ) encoded by different genes. They can be organized into two groups based on their specific $G$ protein coupling. In one group, that includes the $\mathrm{P}_{2} \mathrm{Y}_{1}, \mathrm{P}_{2} \mathrm{Y}_{2}, \mathrm{P}_{2} \mathrm{Y}_{4}, \mathrm{P}_{2} \mathrm{Y}_{6}$ and $\mathrm{P}_{2} \mathrm{Y}_{11}$ receptors, are all coupled to $\mathrm{Gq}$ and the further activation of phospholipase $C \beta$, with the consequent formation of inositol triphosphate (IP3) and the mobilization of intracellular $\mathrm{Ca}^{2+}$. The other group includes the $\mathrm{P}_{2} \mathrm{Y}_{12}, \mathrm{P}_{2} \mathrm{Y}_{13}$ and $\mathrm{P}_{2} \mathrm{Y}_{14}$ receptors, associated with $\mathrm{Gi}$ proteins and inhibiting adenylate cyclase. The $\mathrm{P}_{2} \mathrm{Y}_{11}$ is the only thing that can be coupled to both Gs and Gq proteins (Jacobson et al., 2015).

Concerning the action of dinucleoside polyphosphates and the activation of $\mathrm{P} 2$ receptors, most of the research has been carried out for $\mathrm{Ap}_{\mathrm{n}} \mathrm{A}$ compounds (Hoyle et al., 2001). In this sense, diadenosine polyphosphates can activate all the P2X receptors (Wildman et al., 1999), including the heteromeric P2X2/3. It is noteworthy to indicate that the most active dinucleotide has been $\mathrm{Ap}_{4} \mathrm{~A}$ in most cases. (Pintor and Miras-Portugal, 1995b). Also, the P2X7 was only sensitive to these dinucleotides at concentrations above $1 \mathrm{mM}$, this effect being far from the physiological concentrations of these compounds.

Regarding the $\mathrm{P} 2 \mathrm{Y}$ receptors, $\mathrm{P}_{2} \mathrm{Y}_{1}$ and $\mathrm{P}_{2} \mathrm{Y}_{2}$ are the ones that are stimulated by diadenosine polyphosphates (Patel et al., 2001). The tandem $\mathrm{Ap}_{4} \mathrm{~A}-\mathrm{P}_{2} \mathrm{Y}_{2}$ is of special interest since it participates in many physiological processes in many ocular structures (Fig. 2 see below).

\subsection{Dinucleoside polyphosphate degradation}

The concentration of dinucleoside polyphosphates is tightly regulated by a variety of enzymes, mainly hydrolases that are present in all organisms and generally act on the polyphosphates

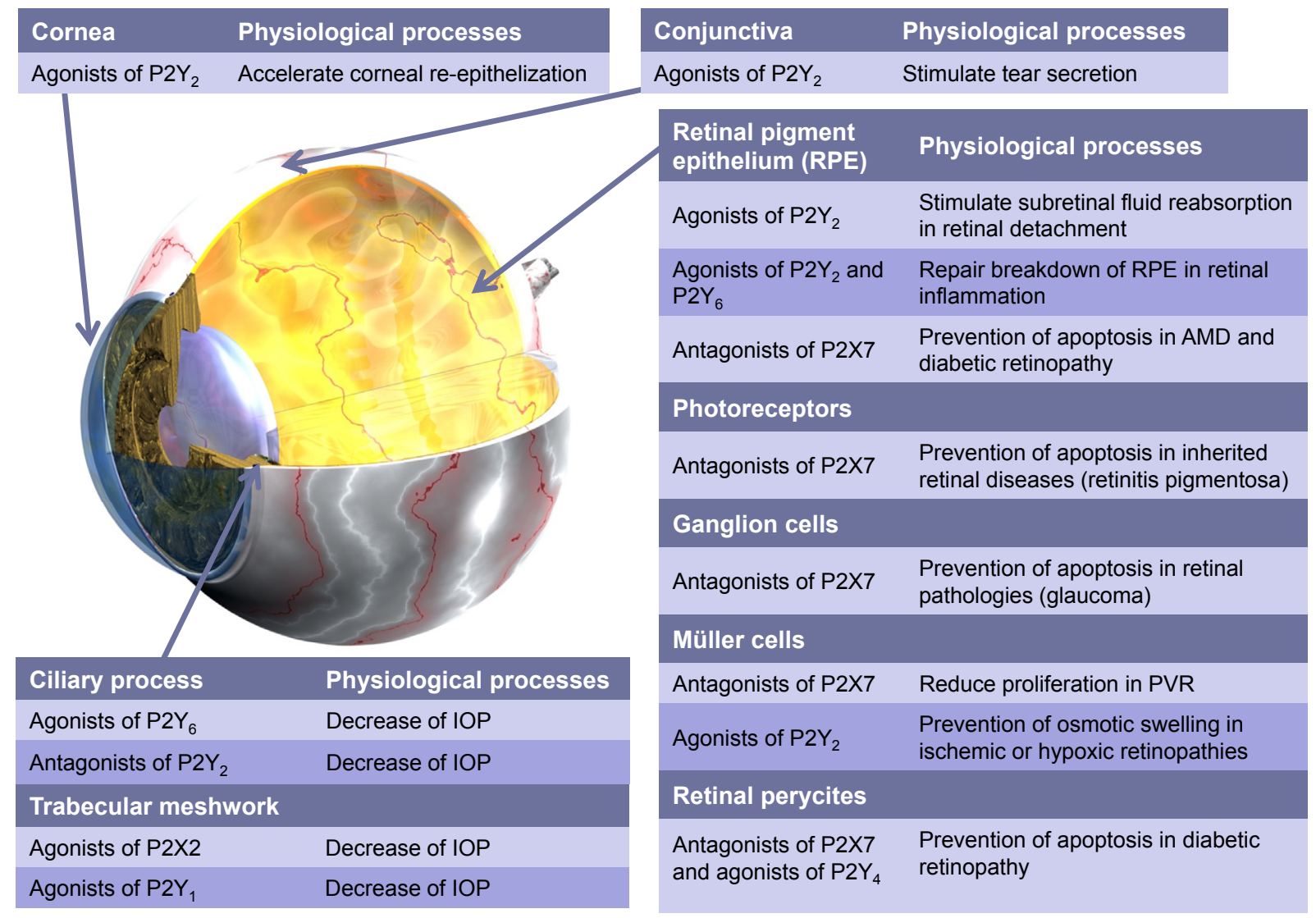

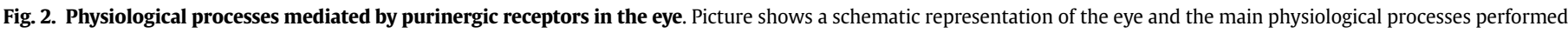
by activation or blockage of purinergic receptors and their therapeutic potential in certain eye pathologies. 
chain of these molecules. The enzymes involved in the catabolism of dinucleoside polyphosphates have been reviewed by Guranowski (Guranowski, 2000).

Extracellular dinucleotides, which regulate physiological processes via P2 receptors activation, are degraded principally by ectonucleotide pyrophosphatase/phosphodiesterases (NPPs) (Asensio et al., 2007; Vollmayer et al., 2003). This family of enzymes are hydrolases located on cell surface and are a type of the so called ecto-nucleotidases (Zimmermann et al., 2012). In vertebrates, NPPs have seven members (NPP1-NPP7) but only three (NPP1-NPP3) can degrade nucleotides (dinucleotides but also nucleoside triphosphates and diphosphates) (Goding et al., 1998; Jin-Hua et al., 1997; Stefan et al., 1999). Dinucleotides degradation by NPPs produce nucleoside monophosphates (NMP) plus nucleoside polyphosphates $\left(\mathrm{NP}_{\mathrm{n}-1}\right)$. Therefore, NPPs can generate metabolites biologically active such as ADP and ATP that are obtained from the naturally occurring diadenosine polyphosphates (Vollmayer et al., 2003; Zimmermann, 2000). These nucleotides can also be degraded by NPPs and essentially through ecto-nucleoside triphosphate diphosphohydrolases (NTPDases), other family of ecto-enzymes that can degrade nucleoside triphosphates and diphosphates (Zimmermann, 1999).

On the other hand, the degradation of diadenosine polyphosphates and their metabolites ATP as well as ADP produce AMP. This nucleoside monophosphate can also be catabolized through ecto-5'-nucleotidase (eN) as well as alkaline phosphatase enzymes (this last ecto-nucleotidase may also act on ATP and ADP molecules) (Zimmermann et al., 2012). Consequently, AMP is converted into the nucleoside adenosine, which mediates purinergic effects via P1 receptors interaction (Jacobson and Gao, 2006).

Finally, extracellular adenosine can be eliminated from the synaptic cleft through cell surface adenosine deaminases that convert adenosine to inosine and/or nucleoside transporters (Bonan, 2012; Franco et al., 1997; Pastor-Anglada and Perez-Torras, 2015). These transporters, equilibrative and concentrative nucleoside transporters, are integral membrane proteins implicated in the cellular uptake of adenosine (Bonan, 2012; Pastor-Anglada and Perez-Torras, 2015).

\section{Dinucleoside polyphosphates in the eye}

\subsection{Ocular surface}

The ocular surface is the outer zone of the eye. It is a functional unit composed of different structures such as corneal and conjunctival epithelium, lacrymal glands, eyelids and tear film. All components of this functional unit are linked through the innervation and vascular immunologic and endocrine systems. The main functions of the ocular surface are to maintain the transparency of the cornea (optic quality issues) and to hydrate and protect the corneal and conjunctival epithelium to the external agents. The tear film is mainly in charge of these functions. It is critical to have a correct volume and stability of the tear film to maintain the integrity of the ocular surface. The loss of the ocular homeostasis provokes serious clinical manifestations as a dry eye, infections of epithelial defects (Gipson, 2007; Knop and Knop, 2007; Paulsen, 2008).

The ocular structure that has probably been investigated in more depth regarding dinucleoside polyphosphates is the ocular surface and specially the tear film. The presence of diadenosine polyphosphates in the tear film has been noted in different conditions and also the different purinergic receptors in the ocular surface that can be activated by the dinucleotides (GuzmanAranguez and Pintor, 2012). Moreover, the effects of the ocular surface of different dinucleotides when these compounds are instilled on the ocular surface have also been previously described (Crooke et al., 2008). In the following sections, the presence and effect of dinucleoside polyphosphates will be reviewed.

\subsubsection{Purinergic receptors in the ocular surface}

$\mathrm{P} 2 \mathrm{X}$ and $\mathrm{P} 2 \mathrm{Y}$ receptors are expressed in different zones of the ocular surface, the $\mathrm{P}_{2} \mathrm{Y}_{2}$ subtype being the most abundant, identified in the corneal and conjunctival epithelium, corneal endothelium and main lacrimal gland (Pintor et al., 2004b). All P2 purinergic receptors described in the ocular surface and their functions are summarized in Table 1. The expression of P2 receptors in different ocular surface locations suggests the involvement of these receptors in the physiology of the eye (Guzman-Aranguez and Pintor, 2012). In fact, during the last decade, the role of several nucleotides and their receptors in ocular processes, including tear secretion (through $\mathrm{P}_{2} \mathrm{Y}_{2}$ receptor) (Jumblatt and Jumblatt, 1998; Murakami et al., 2000), corneal wound healing $\left(\mathrm{P}_{2} \mathrm{Y}_{2}\right.$ is able to accelerate the corneal re-epithelization and proliferation, meanwhile $\mathrm{P}_{2} \mathrm{Y}_{6}$ inhibits the process) (Byun et al., 2016; Crooke et al., 2009; Mediero et al., 2006), and corneal epithelial migration and stromal organization (mediated through P2X7 receptor) have been described (Mankus et al., 2012; Mayo et al., 2008).

\subsubsection{Action of ectodinucleotidases in the ocular surface}

As we mentioned above, the dinucleotides effects on ocular surface are due mainly to $\mathrm{Ap}_{4} \mathrm{~A}$ and $\mathrm{Ap}_{5} \mathrm{~A}$ but also their metabolites such as ATP and adenosine and the ecto-nucleotidases, mainly NPPs, control the availability of these extracellular dinucleotides and their metabolites. In this context, the expression of some ectoenzymes has been detected, including ENPP1 as well as ENPP3 isoforms, NTPD1 isoform and 5NTE in human conjunctival cells obtained by impression cytology (see Fig. 3). Regarding adenosine, ocular surface also present ecto-adenosine deaminases and nucleoside transporters that can control its possible effects (Majumdar et al., 2003; O'Brien et al., 1987).

The existence of conjunctival NPP isoenzymes (Fig. 3) with different substrate specificity might explain, together with the nonneuronal origin of $\mathrm{Ap}_{4} \mathrm{~A}$ and $\mathrm{Ap}_{5} \mathrm{~A}$, the different concentration of these dinucleotides in tear. Nevertheless, Vollmayer and colleagues have proved that NPP1 and NPP3 hydrolyze $A_{4} A$ as well as $A_{5} A$ with similar rates (Vollmayer et al., 2003).

\subsubsection{Presence in the tear film of healthy patients}

The presence of diadenosine polyphosphates in the tear film was studied due to their properties to enhance both tear secretion and to increase the wound healing rate (Guzman-Aranguez et al., 2007, 2011; Pintor et al., 2004a; Pintor et al., 2002b). The exogenous addition of these dinucleotides suggested their presence as natural constituents of tears.

When investigating dinucleotides in tears, this fluid was extracted by using paper strips to perform the Schrimer test (for tear volume measurement), placed in the inferior lid margin of the eye for $5 \mathrm{~min}$ (van Bijsterveld, 1969). The strips were then processed to be evaluated by High Pressure Liquid Chromatography (HPLC), following the procedure described by Pintor et al. (Pintor et al., 1992). The first adenine dinucleotides described in tear were $\mathrm{Ap}_{4} \mathrm{~A}$ and $\mathrm{Ap}_{5} \mathrm{~A}$, which were found in New Zealand rabbit tears (Pintor et al., 2002b). Diadenosine tetraphosphate concentration was $2.92 \pm 0.28 \mu \mathrm{M}$ and diadenosine pentaphosphate concentration was $0.587 \pm 11 \mu \mathrm{M}$. These concentrations would be enough to activate the ocular surface $\mathrm{P} 2$ receptors.

Initially, the hypothesis of the release of these dinucleotides in rabbit tear film was thought to occur via the exocytotic release from the nerve terminals present on the ocular surface, since this 
Table 1

Purinergic receptors expressed in the ocular surface. Adapted from Guzman-Aranguez et al., 2013.

\begin{tabular}{|c|c|c|c|}
\hline P2 subtype & Species & Function & References \\
\hline \multicolumn{4}{|l|}{ Corneal Epithelium } \\
\hline P2X5 & Rat & Undetermined & (Groschel-Stewart et al., 1999) \\
\hline $\mathrm{P} 2 \mathrm{X} 7$ & Rat, mouse and human & Epithelial migration and stroma reorganization & $\begin{array}{l}\text { (Dutot et al., 2008; Groschel-Stewart et al., } \\
\text { 1999; Mayo et al., 2008) }\end{array}$ \\
\hline $\mathrm{P}_{2} \mathrm{Y}_{1}, \mathrm{P}_{2} \mathrm{Y}_{4}$ & Rabbit, rat and human & Undetermined & (Klepeis et al., 2004; Pintor et al., 2004b) \\
\hline $\mathrm{P}_{2} \mathrm{Y}_{2}$ & Monkey, rabbit, rat and human & $\begin{array}{l}\text { Re-epithelization, corneal proliferation and } \\
\text { corneal permeability increasing }\end{array}$ & $\begin{array}{l}\text { (Cowlen et al., 2003; Crooke et al., 2009; Klepeis } \\
\text { et al., 2004; Loma et al., 2015b; Mediero et al., } \\
\text { 2008; Pintor et al., 2004b) }\end{array}$ \\
\hline $\mathrm{P}^{2} \mathrm{Y}_{6}$ & Rabbit, rat and human & $\begin{array}{l}\text { Re-epithelization delay and corneal } \\
\text { proliferation increasing }\end{array}$ & $\begin{array}{l}\text { (Klepeis et al., 2004; Mediero et al., 2006; Pintor } \\
\text { et al., 2004b) }\end{array}$ \\
\hline $\mathrm{P} \mathrm{Y}_{11}$ & Rabbit and human & Undetermined & (Klepeis et al., 2004) \\
\hline \multicolumn{4}{|l|}{ Conjuctival Epithelium } \\
\hline P2X7 & Human & $\begin{array}{l}\text { Membrane permeabilization associated with } \\
\text { iatrogenic pathology }\end{array}$ & (Dutot et al., 2008) \\
\hline $\mathrm{P} \mathrm{Y}_{2}$ & Monkey, dog, rabbit and human & Tear fluid and mucin secretion stimulation & $\begin{array}{l}\text { (Cowlen et al., 2003; Jumblatt and Jumblatt, } \\
\text { 1998; Li et al., 2001; Murakami et al., 2000; } \\
\text { Terakado et al., 2014) }\end{array}$ \\
\hline \multicolumn{4}{|l|}{ Corneal Endothelium } \\
\hline $\mathrm{P}_{2} \mathrm{Y}_{1}$ & Bovine & Intracellular $\mathrm{Ca} 2+$ concentration increasing & (Gomes et al., 2005) \\
\hline $\begin{array}{l}\mathrm{P} 2 \mathrm{Y}_{2} \\
\text { Lacrymal Gland }\end{array}$ & Bovine, monkey and rabbit & Intracellular $\mathrm{Ca} 2+$ concentration increasing & (Cowlen et al., 2003; Gomes et al., 2005) \\
\hline $\mathrm{P} 2 \mathrm{X}_{1}, \mathrm{P} 2 \mathrm{X}_{2}, \mathrm{P} 2 \mathrm{X}_{4}, \mathrm{P} 2 \mathrm{X}_{5}, \mathrm{P} 2 \mathrm{X}_{6}$ & Rat & Undetermined & (Hodges et al., 2009; Kamada et al., 2012) \\
\hline $\mathrm{P} 2 \mathrm{X}_{3}, \mathrm{P} 2 \mathrm{X}_{7}$ & Rat & $\begin{array}{l}\text { Intracellular } \mathrm{Ca} 2+\text { concentration increasing and } \\
\text { protein secretion }\end{array}$ & (Hodges et al., 2011; Hodges et al., 2009) \\
\hline $\mathrm{P}_{2} \mathrm{Y}_{2}, \mathrm{P}_{2} \mathrm{Y}_{4}, \mathrm{P}_{2} \mathrm{Y}_{12}, \mathrm{P}_{2} \mathrm{Y}_{14}$ & Rat & Undetermined & (Kamada et al., 2012; Tanioka et al., 2014) \\
\hline $\begin{array}{l}\mathrm{P}_{2} \mathrm{Y}_{1}, \mathrm{P}_{2} \mathrm{Y}_{11}, \mathrm{P}_{2} \mathrm{Y}_{13} \\
\text { Meibomian Glands (Eyelid) }\end{array}$ & Rat & Intracellular $\mathrm{Ca} 2+$ concentration increasing & (Kamada et al., 2012; Ohtomo et al., 2011) \\
\hline $\mathrm{P}_{2} \mathrm{Y}_{2}$ & Rat and monkey & Undetermined & (Cowlen et al., 2003; Tanioka et al., 2014) \\
\hline
\end{tabular}

mechanism has been described for these dinucleotides in the central nervous system (Pintor et al., 2002a). However, when the ocular denervation was performed in rabbits, the release of these dinucleotides was similar to non-denervated animals, indicating that the delivery was not from the nerve terminals by a $\mathrm{Ca}^{2+}$ independent mechanism in the CNS (Guzman-Aranguez et al., 2007).

The mechanism for the dinucleotide release in the ocular

\section{$M \quad$ NTPD1 5NTE ENPP1 ENPP3}

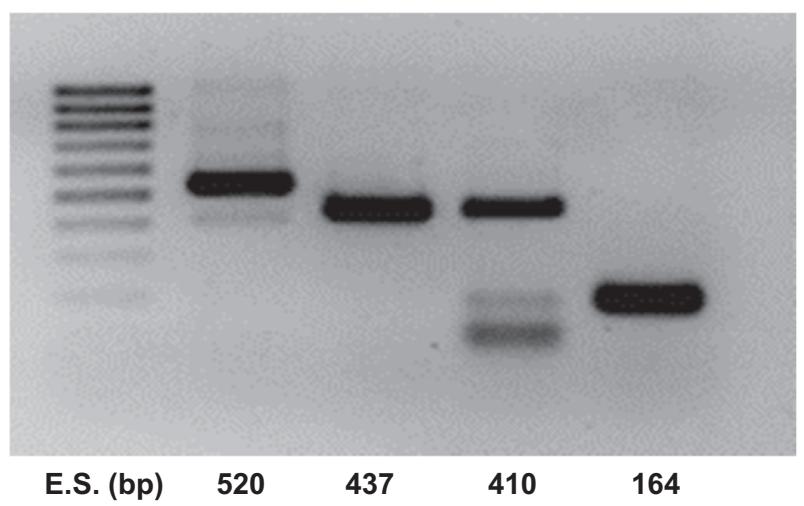

Fig. 3. Presence of ecto-nucleotidases transcripts in human conjunctival epithelial cells. Agarose gel electrophoresis images of conjunctival NTPD1, eN, NPP1 and NPP3 partial gene transcripts. RT-PCR assays were carried out with total RNA isolated from conjunctival cells obtained by impression cytology and specific primers. RT-PCR products obtained with NTPD1 specific forward (5'-ATGGCAAGGACTACAATG-3') and reverse $\left(5^{\prime}\right.$-GAAAAGCAGTATTCACTCA- $\left.3^{\prime}\right)$ primers (lane 1 , expect amplicon size $=520$ bp), using eN specific forward (5'-GATCGAGCCACTCCTCAAA- $\left.3^{\prime}\right)$ and reverse $\left(5^{\prime}-\right.$ GCCCATCATCAGAAGTGAC- $3^{\prime}$ ) primers (lane 2, expect amplicon size $=437 \mathrm{bp}$ ), using NPP1 specific forward (5'-GAATTCTTGAGTGGCTACAGCTTCCTA-3') and reverse (5'CTCTAGAAATGCTGGGTTTGGCTCCCGGCA-3') primers (lane 3, expect amplicon size= $410 \mathrm{bp}$ ) and using NPP3 specific forward (5'-CGACTGCACTATGCCAAGAA- $\left.3^{\prime}\right)$ and reverse ( $5^{\prime}$-GGTCCATGTGCCAGAAAGAT- $3^{\prime}$ ) primers (lane 4 , expect amplicon size $=164$ bp); Lane M, 100 bp DNA ladder molecular weight marker. surface was studied in humans. The first study confirmed the presence of diadenosine polyphosphates in the human tear film (Pintor et al., 2002a). The presence of $\mathrm{Ap}_{4} \mathrm{~A}$ and $\mathrm{Ap}_{5} \mathrm{~A}$ was found, as in rabbit model, and it was possible to measure small levels of $\mathrm{Ap}_{3} \mathrm{~A}$. In human tears, the levels of diadenosine polyphosphates are $2.1 \pm 2.2 \mathrm{nM}, 108.7 \pm 18.3 \mathrm{nM}$, and $37.1 \pm 6.2 \mathrm{nM}$ for $\mathrm{Ap}_{3} \mathrm{~A}, \mathrm{Ap}_{4} \mathrm{~A}$, and $\mathrm{Ap}_{5} \mathrm{~A}$, respectively. The concentrations of diadenosine polyphosphates in rabbits were one order of magnitude higher than that found in humans, but the $A_{4} A / A_{5} A$ ratio in rabbits and humans was almost identical, with ratios of 2.97 and 2.91 , respectively.

In addition, ATP seems to be present in tears contributing to the nucleotide pool present in tears, therefore modulating some physiological processes on the eye surface. Srinivas and co-workers found that its presence in tears is a consequence of shear stress induced on the corneal epithelial cells in cultured rabbit corneal epithelial cells model (Srinivas et al., 2002). This fact suggested that other nucleotides such as diadenosine polyphosphates could be also released in a similar way. Carracedo and co-workers found that shear stress stimuli induced $\mathrm{Ap}_{4} \mathrm{~A}$ and $\mathrm{Ap}_{5} \mathrm{~A}$ release from human corneal epithelial cells both In vitro and In Vivo (Carracedo et al., 2013). The results obtained In vitro were consistent with Srinivas findings (Srinivas et al., 2002). Since in the studies performed by Carracedo, shear stress did not increase the amount of lactate dehydrogenase in human, the presence of $A_{4} A$ and $A_{5} A$ was not a consequence of cell rupture, although the exact mechanism of release remains to be determined. Mechanical perturbations such as cell stretching (Patel et al., 2005), hydrostatic pressure (Cockayne et al., 2000; Ferguson et al., 1997; Knight and Burnstock, 2001) and compressive stress (Sauer et al., 2000) seem to be the candidates to trigger the release of these dinucleotides. The motion of the upper eyelid during the blinking process seems to be responsible for exerting shear stress on the epithelial cells and therefore increasing the levels of both diadenosine polyphosphates, concomitantly with the increase in the blinking frequency (Carracedo et al., 2013).

$\mathrm{Ap}_{4} \mathrm{~A}$ and $\mathrm{Ap}_{5} \mathrm{~A}$ concentrations in tear film of healthy patients 
described above were collected in subjects from 18 to 38 years old (Pintor et al., 2002a). The age is considered one the most relevant factors to suffer dry eye, this may be due to the reduction in the lacrimal production or due to the increase in the evaporation rate associated with aging (Mathers et al., 1996). There are many studies corroborating this assumption, in spite of the percentage of prevalence which is very variable, changing from $5 \%$ to $35 \%$ at 50 years old, or $20 \%-40 \%$ at 80 years of age (Moss et al., 2000; Schein et al., 1997) (Chia et al., 2003; Lee et al., 2002; Lin et al., 2003; Schaumberg et al., 2003, 2009; Viso et al., 2009), although there is consensus that the prevalence increases significantly after 50 years of age. The other main factor to develop dry eye is gender, it being more common in women than men. The Beaver Dam study showed a prevalence of dry eye of $18 \%$ in women and only $11 \%$ in men, and some other studies described even higher differences between women and men (Paulsen et al., 2014). The principal reason for these differences would be the hormonal factor (Guillon and Maissa, 2010).

Due to the effect of some dinucleotides on the tear secretion (see section 2.1.7.), our research group considered it interesting to evaluate the variations in diadenosine polyphosphates concentrations as a function of aging and gender. Ninety-three healthy subjects were recruited to participate in the study. The age range was from 7 to 90 years old. Of the total 93 subjects, 47 were men and 46 were women, all of them without any ocular surface pathology. The levels of $A p_{4} A$ and $A p_{5} A$ were analyzed with and without anesthetic, discarding $\mathrm{Ap}_{3} \mathrm{~A}$ due to the low concentration found in a previously study (Pintor et al., 2002a).

The obtained results showed that $\mathrm{Ap}_{4} \mathrm{~A}$ concentration remained stable until 50 years old, increasing its concentration significantly from this age ( $p$ value $<0.01$; one way ANOVA). However, no significant changes were found for $A_{5} A$ concentration throughout the age range $(p=0.245$, one way ANOVA, Fig. 4$)$. When comparing $\mathrm{Ap}_{4} \mathrm{~A}$ concentrations in function of gender, it was found that there was more diadenosine tetraphosphate in men tears than in women, but without a statistically significant difference $(\mathrm{p}$ value $=0.078$; $\mathrm{t}-$ Student test for independent samples). For $A_{5} A$, the concentrations were similar in both groups of subjects ( $\mathrm{p}$ value $=0.761$; $\mathrm{t}-$ Student test for independent samples, Fig. 5). As we will see in the following section, a correlation between the age (dry eye disease main factor), and $\mathrm{Ap}_{4} \mathrm{~A}$ concentration appears to exist.

\subsubsection{Presence in ocular surface pathology}

The relationship between dry eye and dinucleotides has been

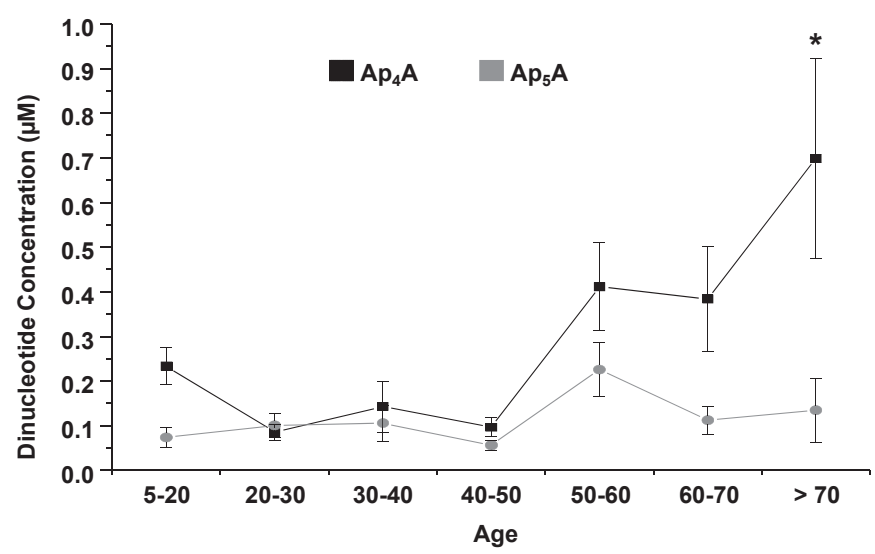

Fig. 4. Age-related variations in $A_{4} A$ and $A p_{5} A$ concentrations in tear. Graph shows the significant increase on $A_{4} A$ levels throughout age $\left({ }^{*} p<0.01\right.$, one way ANOVA), while there are no differences on $A_{5} A$ levels $(p=0.245$, one way ANOVA). Values represent means \pm SEM $(n=93)$.
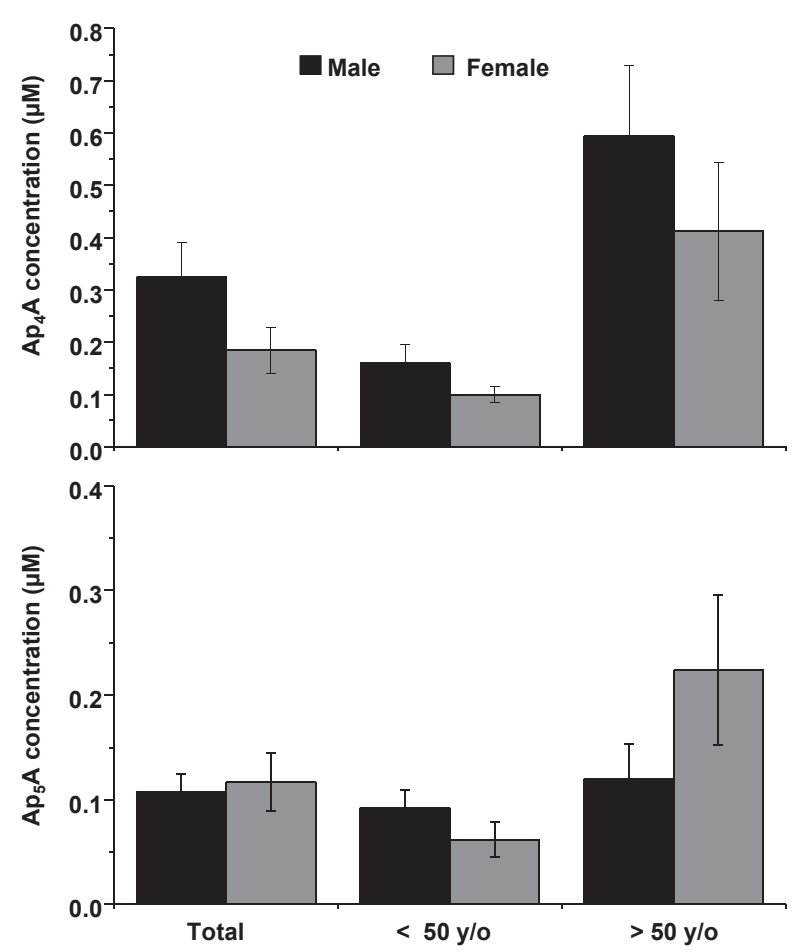

Fig. 5. Sex-related differences in $A_{4} A$ and $A p_{5} A$ concentrations in tear. Upper panel shows $\mathrm{Ap}_{4} \mathrm{~A}$ concentrations in tear in the whole group and the subgroups of older and younger than 50 years old. Lower panel shows $\mathrm{Ap}_{5} \mathrm{~A}$ concentrations in tear in the whole group and the subgroups of older and younger than 50 years old. There are no differences in dinucleotides levels between genders in any groups $(p>0.05$, t-Student test for independent samples), even so, there is a significant increase in $A_{4} A$ and $A_{5} A$ concentration groups in subjects older than 50 years in males and females $(p<0.01$ in $\mathrm{Ap}_{4} \mathrm{~A}$ levels and $p<0.05$ in $\mathrm{Ap}_{5} \mathrm{~A}$ levels, t-Student test for independent samples). Values represent means $\pm \mathrm{SEM}$.

proposed in two different ways: as molecular biomarker and as treatment for the pathology. Peral and co-workers were the first to evaluate the levels of diadenosine polyphosphates in tear secretions in two groups of dry eye symptomatic subjects, one with low tear secretion volume and another with normal tear volume (Peral et al., 2006). They found that $A_{4} A$ and $A_{5} A$ were increased 5- and 1.5 -fold in dry eye subjects with normal tear volume, respectively, compared with healthy subjects in the same age range. The dinucleotide concentrations were $0.590 \pm 0.330 \mu \mathrm{M}$ for $\mathrm{Ap}_{4} \mathrm{~A}$ and $0.058 \pm 0.017 \mu \mathrm{M}$ for $\mathrm{Ap}_{5} \mathrm{~A}$. For symptomatic patients with low tear production the increase was higher, being 100- and 345-fold more than the value obtained in the healthy group. The concentrations were $10.68 \pm 1.87 \mu \mathrm{M}$ for $\mathrm{Ap}_{4} \mathrm{~A}$ and $12.45 \pm 0.20 \mu \mathrm{M}$ for $\mathrm{Ap}_{5} \mathrm{~A}$. From these results, the authors proposed these molecules as an objective biomarker for scoring the severity of dry eye.

In 2010, a research paper was published about the diadenosine polyphosphate concentrations in one of the most severe types of dry eye, Sjögren Syndrome (Carracedo et al., 2010). This autoimmune disorder is produced when the immune system attacks its own exocrine glands by mistake, especially the salivary and lacrimal ones (Srinivasan and Slomovic, 2007). The mean concentrations of $\mathrm{Ap}_{4} \mathrm{~A}$, and $\mathrm{Ap}_{5} \mathrm{~A}$ in the Sjögren syndrome group were $2.54 \pm 1.02 \mu \mathrm{M}$ and $26.13 \pm 6.95 \mu \mathrm{M}$, respectively. When this group was divided into two subgroups, normal and low tear secretion, the concentrations in normal tear secretion group were $0.47 \pm 0.20 \mu \mathrm{M}$ for $\mathrm{Ap}_{4} \mathrm{~A}$ and $8.30 \pm 3.27 \mu \mathrm{M}$ for $\mathrm{Ap}_{5} \mathrm{~A}$. The subgroup with low tear secretion showed dinucleotide concentrations of $4.09 \pm 1.36 \mu \mathrm{M}$ and $39.51 \pm 8.45 \mu \mathrm{M}$ for $\mathrm{Ap}_{4} \mathrm{~A}$ and $\mathrm{Ap}_{5} \mathrm{~A}$, respectively. It has been reported that the upregulated presence of $\mathrm{P}_{2} \mathrm{Y}_{2}$ in the salivary 
glands increases the epidermal growth factor receptor (EGFR) dependent expression of vascular cell adhesion molecule (VCAM)-1 and provokes the lymphocyte infiltration associated with the inflammation (Baker et al., 2008; Schrader et al., 2005). Meanwhile this receptor has not yet been located in the lacrimal gland, a similar effect could occur in Sjögren Syndrome (Tanioka et al., 2014). Therefore, the high concentrations of diadenosine polyphosphates in Sjögren syndrome patients would not be able to stimulate more lacrimation; they may even increase lymphocyte infiltration.

Another condition related with dinucleoside concentration in tears is congenital Aniridia. This inherited pathology is a rare disorder due to the mutation of the PAX6 gene (Glaser et al., 1992, 1994), located in the short arm of the chromosome 11. The main feature of aniridia is the partial or total absence of the iris, but the ocular surface is also affected with limbal stem cell deficiency, tear film disorders, corneal keratopathy and dry eye (Mayer et al., 2003). It seems that dinucleoside play an important role in the progression of the pathology, since the $\mathrm{Ap}_{4} \mathrm{~A}$ and $\mathrm{Ap}_{5} \mathrm{~A}$ concentration increases with age, being higher in patients over 40 years of age than in younger aniridia patients. It has been demonstrated that P2 purinergic receptors are associated with differentiation, proliferation and neurogenesis in neonatal and adult mouse olfactory epithelium (Jia and Hegg, 2012). In the corneal epithelium the cell proliferation process is initiated by $\mathrm{P}_{2} \mathrm{Y}_{2}$ receptor activation via the ERK1/2 pathway (Muscella et al., 2004). Therefore, the increased levels of diadenosine polyphosphates have been proposed as a compensatory mechanism to stimulate the proliferation and differentiation of limbal stem cells that are deficient in aniridia disorder.

Dinucleotide presence in the tear film has been related to dry eye disorders, cell migration and proliferation disorders. Inflammation is another biological process where the purinergic receptors and dinucleotides are involved (Guzman-Aranguez et al., 2014). The main ocular surface condition, with dry eye, which is probably associated with inflammation is keratoconus. It is a corneal disorder characterized by progressive corneal stromal thinning, a coneshaped protrusion of the corneal surface (ectasia) (Davidson et al., 2014; Romero-Jimenez et al., 2010), that creates alterations of the corneal tissue surface that result in visual distortion and reduced tear film quality. Tissue degradation by keratoconus involves the expression of inflammatory mediators, and therefore patients exhibit higher levels of pro-inflammatory cytokines, cell adhesion molecules, and matrix metalloproteinases (MMPs) compared with

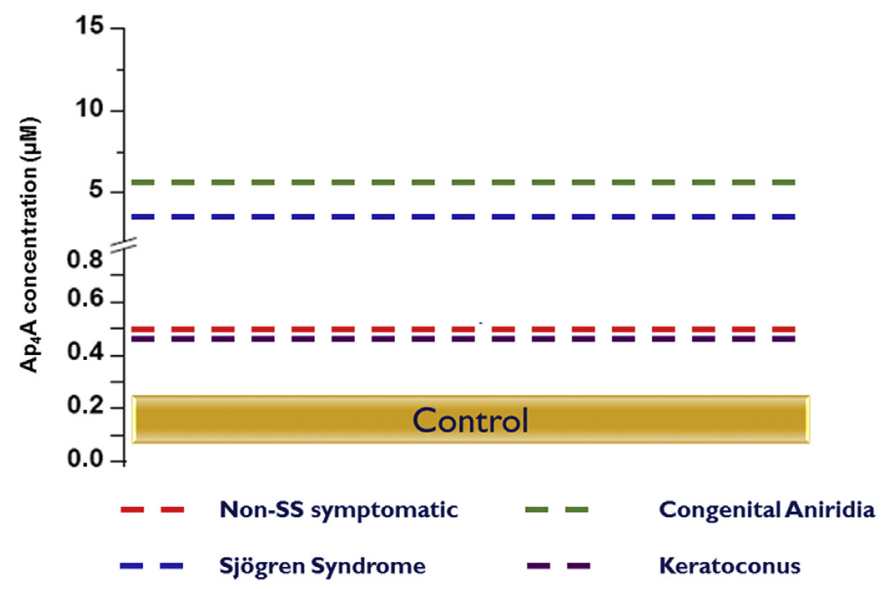

Fig. 6. $A p_{4} A$ concentrations in different ocular conditions. Picture shows the increase on $\mathrm{Ap}_{4} \mathrm{~A}$ levels averages in different pathological processes related with dry eye condition compared with normal values. $\mathrm{Ap}_{4} \mathrm{~A}$ is a potential biomarker of dry eye condition, which its cutoff is over $0.5 \mu \mathrm{M} \mathrm{Ap} \mathrm{A}_{4} \mathrm{~A}$ concentration in tear film. normal individuals (Galvis et al., 2015; Lema et al., 2008; McMonnies, 2015). The concentration of $\mathrm{Ap}_{4} \mathrm{~A}$ is higher in keratoconus patients than in healthy subjects (Carracedo et al., 2015b, 2016). The reasons for this increasing are related with mechanical stimulation of the corneal epithelial cell, due to eye rubbing or also gas permeable (GP) contact lenses wearing. In both cases this could be the trigger to induce the release of the diadenosine tetraphosphate.

All studies performed on the relationship of $A_{4} A$ and dry eye disorders showed the increment of the concentration of this molecule in the tear film of dry eye patients, so this diadenosine polyphosphate has been proposed as a diagnostic tool for this condition. Fig. 6 summarizes the levels of $\mathrm{Ap}_{4} \mathrm{~A}$ concentration in different ocular conditions compared with normal values.

\subsubsection{Presence in contact lens wearers}

As commented above, Carracedo and co-workers demonstrated that forced blinking in healthy subjects provokes an increment of $\mathrm{Ap}_{4} \mathrm{~A}$ and $\mathrm{Ap}_{5} \mathrm{~A}$ concentration in tears, corroborating In vivo that these dinucleotides are released by shear stress from the corneal epithelium (Carracedo et al., 2013). It is reasonable to think that mechanical stimulation by contact lens wearing may also induce dinucleotide release, especially if the lens is not well fitted.

There are some different designs and materials for contact lenses. Both parameters are important to provoke more or less shear stress over the ocular surface. Broadly speaking, contact lenses could be manufactured with soft and rigid materials. Actually, the most common soft material is based on silicone and fluoride molecules to enhance the oxygen transmissibility, and the rigid materials are gas permeable, seeking the same oxygen permeability than soft material (Jones et al., 2013; Nichols et al., 2013). The design of contact lenses is also an important factor to take into account. Soft contact lenses have large diameters, beyond the limbus with a slightly movement during blinking (MaldonadoCodina and Efron, 2004; Wolffsohn et al., 2013). Nevertheless, rigid gas permeable lenses have a small diameter with more edge lift and movement than soft contact lenses, provoking more discomfort during the wearing (Brennan et al., 1987; Carracedo et al., 2015a; Cornish and Sulaiman, 1996; Elbendary and Abou Samra, 2013; Fink et al., 1992). Both contact lenses are bearing over the cornea Currently, there is a rigid gas permeable special design, called mini scleral lens and mainly indicated for keratoconus and severe dry eye which does not bear over the cornea, keeping a post lens tear meniscus between the cornea and the lens. As with soft contact lenses, its diameter is large, from $15.00 \mathrm{~mm}$ to $18.00 \mathrm{~mm}$ and therefore saving the cornea and the limbus (van der Worp et al., 2014).

The effect of contact lens wearing on tear dinucleotide concentration has been studied in different material and designs. Guzman et al. reported the effect of soft contact lenses poorly fitted in the diadenosine polyphosphates concentration (GuzmanAranguez et al., 2007). Twenty-three healthy subjects were recruited who wore soft contact lenses for $8 \mathrm{~h}$ showed $\mathrm{Ap}_{4} \mathrm{~A}$ and $A_{5} A$ tear levels significantly increased due to the presence of the contact lens, being the increasing 20 fold greater for $A_{4} A$ than for $A p_{5} A$. They suggested that measurement of tear dinucleotides might be used as an index of satisfactory contact lens fitting (Guzman-Aranguez et al., 2015).

Moreover, the relationship between dinucleotides in tears and rigid gas permeable lenses was studied for two different designs (Carracedo et al., 2012). Alignment-fit aspheric rigid gas permeable lenses worn on a daily basis and reverse geometry lenses worn overnight were fitted in the mentioned study. Both contact lenses have the same material but not the same indication and wearing basis. The lenses which are worn during the day provoke more 
A)
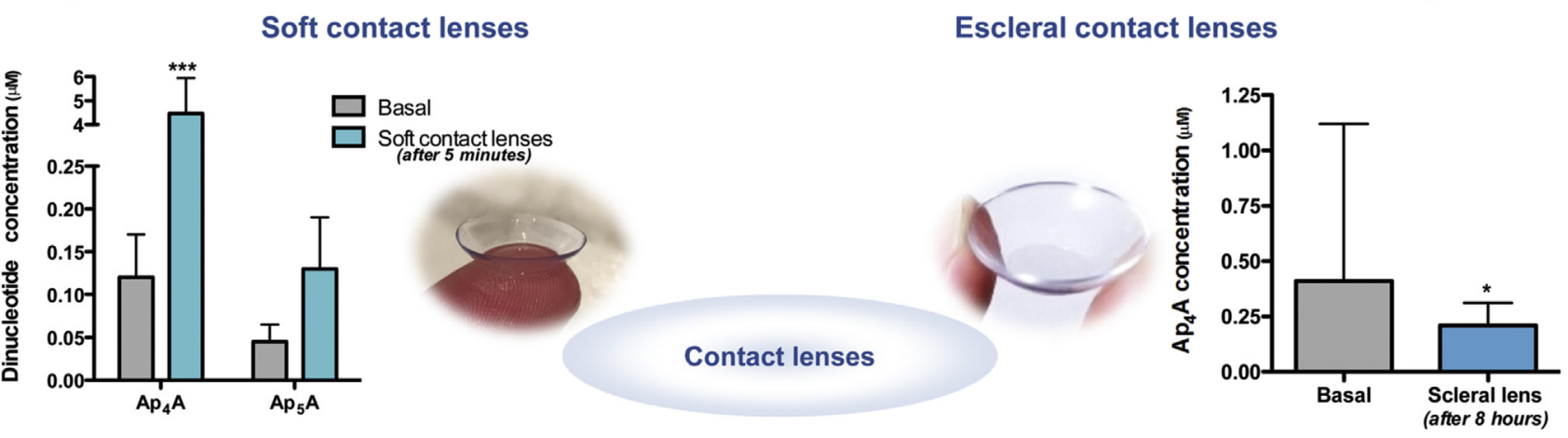

C)

Rigid gas permeable lenses
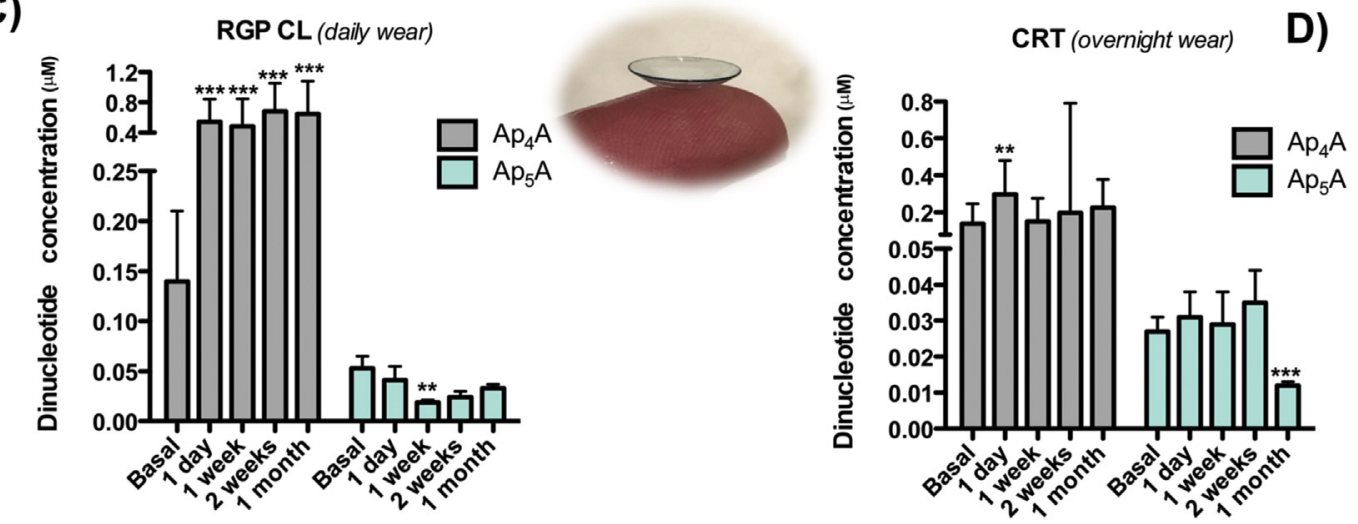

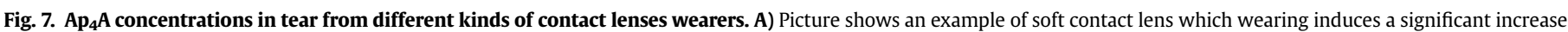

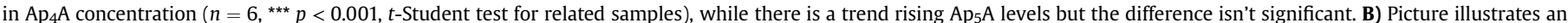

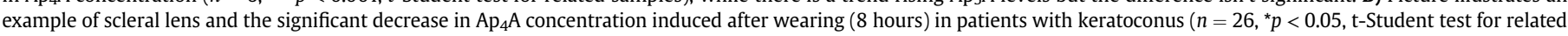

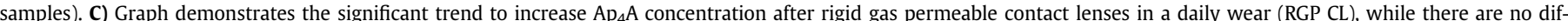

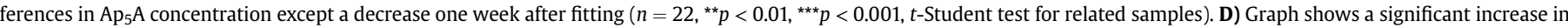

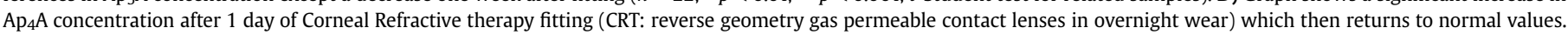

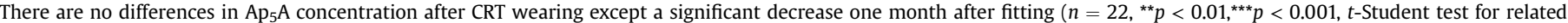
samples). Values represent means \pm SEM.

shear stress on the ocular surface due to the blinking mechanism, but lenses for overnight wearing do not have movement due to lack of blinking during the sleep period. This report found that patients with $\mathrm{Ap}_{4} \mathrm{~A}$ increased its concentration in tears with both lenses designs in the first day after fitting, increasing 4- and 2-fold compared with the baseline visit, respectively. After one month, $\mathrm{Ap}_{4} \mathrm{~A}$ continued increasing significantly with alignment-fit lenses but with lens overnight wear, $\mathrm{Ap}_{4} \mathrm{~A}$ concentrations returned to baseline levels after 1 week. However, $\mathrm{Ap}_{5} \mathrm{~A}$ concentrations remained stable during the study in both groups. This result shows again the effect of the shear stress over the ocular surface stimulating dinucleotide secretion.

As described above, scleral lenses are special contact lenses indicated for severe dry eye and keratoconus patients which do not bear over the cornea and its movement in the eye is very limited. It was interesting to study its wearing over the $\mathrm{Ap}_{4} \mathrm{~A}$ concentration in tears. A study recently published, shows the results in keratoconus patients before and after eight hours of wearing (Carracedo et al., 2016). Ap 4 A concentrations decreased after scleral lens wear from $0.41 \pm 0.71 \mu \mathrm{M}$ to $0.21 \pm 0.52 \mu \mathrm{M}$, being statistically significant. It was expected that dinucleotide concentration remained stable but surprisingly the concentration was lower. This fact could be due to $\mathrm{Ap}_{4} \mathrm{~A}$ degradation to its metabolites since the tear is stagnant behind the contact lens during eight hours. Fig. 7 summarizes the $\mathrm{Ap}_{4} \mathrm{~A}$ concentration for all contact lenses reported in the literature.

\subsubsection{Presence after ocular surface surgery}

Another situation where the dinucleotide concentration in the tear film is interesting to be evaluated is after ocular surface surgery. The most common reason to undergo surgery in the ocular surface is the refractive correction. There are some types of procedures to do that but the most habitual are Laser in situ keratomileusis (LASIK) and photorefractive keratectomy (PRK). Both techniques are safe and effective methods producing similar refractive outcomes (Nejima et al., 2005; Toda, 2008). LASIK, the lamellar flat cut induces sensory deprivation by severing the damage of stromal nerves. This nerve ablation provokes some ocular surface complications as dry eye sensation. However, PRK causes damage to the corneal sensory nerves by a debridement of corneal epithelium and stromal ablation (Perez-Santonja et al., 1999). Presumably, if dinucleotides were released from nerve endings, patients who have had LASIK or PRK would show changes in tear levels of diadenosine polyphosphates.

Carracedo and co-workers found that the concentration of $\mathrm{Ap}_{4} \mathrm{~A}$ rises in tears 5 and 3.5 fold compared with the pre-surgery dinucleotide values in both LASIK and PRK surgery in the next day after surgery, probably as consequence of corneal damage during the procedure (Carracedo et al., 2014). After two weeks of both surgeries, the concentration decreases close to basal values although in LASIK it remains statistically higher. At the end of the study, 3 months later, the concentration was very similar to the pre- 
operative visit for both techniques. Guzman et al. have found that $\mathrm{Ap}_{4} \mathrm{~A}$ trend to be higher than baseline, but not statistically significant, one week after LASIK surgery (Guzman-Aranguez et al., 2007). The results from both studies matched, although it is important to notice that the lack of statistical significance in the study by Guzman et al., is probably due to the small size of the sample. For $A_{5} A$, the concentration remained stable in both studies during all the period evaluated.

In a non-published study performed by our research group, dinucleotide concentration in tears was also measured in patients after Intraocular collamer Lens (ICL) surgery. This refractive surgery technique consists of introducing an intraocular contact lens in the anterior chamber through a small incision in the corneal periphery, close to the limbus (Kamiya et al., 2010; Uusitalo et al., 2002). With this procedure the corneal neural network is preserved (Alfonso et al., 2013; Ali et al., 2014). Our preliminary results show that both $\mathrm{Ap}_{4} \mathrm{~A}$ and $\mathrm{Ap}_{5} \mathrm{~A}$ do not change their concentrations in the tear film throughout the study. This fact suggests that diadenosine polyphosphates present in tears are not released by the nerve terminals present at the ocular surface, but it rather confirms that the dinucleotides delivered from ocular surface epithelium is induced by shear stress.

There are some studies describing how $\mathrm{Ap}_{4} \mathrm{~A}$ has the ability to stimulate epithelial cell migration. In contrast, $\mathrm{Ap}_{5} \mathrm{~A}$ has the opposite effect, inhibiting the cell migration (Crooke et al., 2009; Mediero et al., 2009, 2008, 2006). So, the high concentration of $\mathrm{Ap}_{4} \mathrm{~A}$ on the day after LASIK and PRK surgery could be used to accelerate the wound healing process.

\subsubsection{Effect on tear secretion}

Tear secretion is a physiological process because the tear forms the interface between the air and the ocular tissues. To lubricate and to provide nutrients to the ocular surface tissues and to protect against infections are the more critical features of the tear film. For a correct tear volume and stability, it is very important to maintain a compensated tear composition. A failure in the tear secretion may provoke several negative effects in the ocular surface such as discomfort, dryness, irritation or corneal and conjunctival staining (Herrero-Vanrell and Peral, 2007). Dinucleotides participate in the secretion process of some compounds of tear film like aqueous component, mucins and proteins.

The presence of diadenosine polyphosphates in tears of both animals and humans suggests that they may modify the physiology of the ocular surface. Diadenosine tetraphosphate have demonstrated their capability to increase the tear volume in the ocular surface (Pintor et al., 2002b). In the case of $\mathrm{Ap}_{4} \mathrm{~A}$ the increment is up $60 \%$ compared to baseline values in experiments performed with New Zealand white rabbits. $A_{5} A$ and $A_{6} A$ also significantly increased tear production by about $20 \%$ but, $A p_{2} A$ and $A p_{3} A$ are completely ineffective. However, it has not been fully clarified if the effect of these dinucleotides is to induce tear production at the lacrymal gland or in other secretory structures. The studies performed with animal models, suppressing the effect with RB-2, suggest that diadenosine polyphosphates act as agonist of $\mathrm{P}_{2} \mathrm{Y}_{2}$ receptors for increasing the tear production (Murakami et al., 2000; Pintor et al., 2002b). Curiously, the combination of melatonin with $\mathrm{Ap}_{4} \mathrm{~A}$ enhances the effect of the diadenosine over the tear secretion in an animal model, but melatonin does not have any effect when it is applied alone. The authors blocked the effect of this combination applying luzindole, an antagonist of melatonin receptors (Hoyle et al., 2006). It has not been described how melatonin and its receptors increase the effect of $\mathrm{Ap}_{4} \mathrm{~A}$ but a possible mechanism is the heterodimerization of both dinucleotides and melatonin receptors. Both families receptor are coupled to $\mathrm{G}$-protein and it has been suggested that actually these receptors could be organized as heterodimers between different G-protein coupled families (Levoye et al., 2006).

Other dinucleotides which demonstrate their secretagogue propierties is $\mathrm{Gp}_{4} \mathrm{G}$ and $\mathrm{Up}_{4} \mathrm{U}$. Recently in our lab, it has been proved that diguanine tetraphosphate $\left(\mathrm{Gp}_{4} \mathrm{G}\right)$ increases tear secretion in around $40 \%$ above normal tear values in New Zealand White rabbits. As diadenosine tetraphosphate, it is expected that this action is mediated by $\mathrm{P}_{2} \mathrm{Y}_{2}$ (Guzman-Aranguez et al., 2015). But the dinucleotide probably most studied is $\mathrm{Up}_{4} \mathrm{U}$, also called INS365. First studies in animal models showed its properties to enhance tear secretion (Fujihara et al., 2001; Murakami et al., 2000, 2002; Yerxa et al., 2002a). These results, as a secretagogue, were the prelude of Diquafosol, an ophthalmic formulation based on this compound, developed as a new treatment for dry eye and was recently approved for marketing in Japan and South Korea (Jacobson et al., 2012; Nakamura et al., 2012).

Diquafosol has shown its capability to increase the aqueous and mucin portion of tears (Murakami et al., 2004; Nakamura et al., 2012; Takamura et al., 2012; Tauber et al., 2004). In recent years, diquafosol has been used for treating different conditions related with dry eye (Table 2). This dinucleotide improves the tear secretion and symptomatology in Sjögren syndrome (Bremond-Gignac et al., 2014; Yokoi et al., 2015), aqueous deficient dry eye (Koh et al., 2013a, 2014), contact lens wearers (Nagahara et al., 2015), Meibomian gland dysfunction (Arita et al., 2013; Yamaguchi et al., 2015), dry eye related with cataract surgery (Miyake et al., 2014; Park et al., 2015), even in normal eyes (Gendaszewska-Darmach and Kucharska, 2011; Nam et al., 2015; Yokoi et al., 2014). Regarding the safe use of diquafosol, the majority of adverse reactions, found in different clinical trials, were of mild severity, and no serious treatment-related adverse events were reported. Adverse reactions were observed in $6.3 \%$ of patients, and the major adverse reactions were eye irritation, and eye pain. It seems that good tolerance shown by diquafosol ophthalmic solution 3\% remained in the longer term (Takamura et al., 2012; Wu et al., 2015; Yamaguchi et al., 2014).

\subsubsection{Effect on tear components}

The tear film is a complex solution composed of proteins, lipids, carbohydrates and electrolytes. Two main features of the tear film are to protect the ocular surface against potential pathogens and to lubricate and wet the corneal and conjunctival epithelia. So, the tear film has some antimicrobial components that are able to kill the pathogens or at least to inhibit their replication. The main proteins in the tear film performing this task are lysozyme, lactoferrin, immunoglobulin A (IgA) and tear lipocaline (Farris, 1986; Kuizenga et al., 1996; Cabrera et al., 1997).

Lysozime presents a bactericide action against gram-positive bacteria, such as Micrococus lisodeikticus, catalyzing the hydrolysis of 1,4- $\beta$ junctions between $N$-acetylmuramic acid and $N$-acetyl-Dglucosamine in the main chain of peptidoglycans of cell membrane (Burman et al., 1991; Qasba and Kumar, 1997). This protein is secreted by the main and accessories lacrymal glands, representing $25 \%$ of total proteins in the tear film. Peral and co-workers investigated the effect of dinucleotide instillation on the lysozyme concentration in the tear film (Peral et al., 2008). Their hypothesis was based on several studies that have shown a decrease in the concentration of lysozyme in patients with dry eye (Caffery et al., 2008; Mackie and Seal, 1984; van Bijsterveld, 1969). The topical application of $100 \mu \mathrm{M}$ of $\mathrm{Ap}_{4} \mathrm{~A}$ and $\mathrm{Up}_{4} \mathrm{U}$ (aka diquafosol) increased the lysozyme levels after one hour of instillation, remaining higher than baseline during four hours. The maximum value was reached at two hours for both dinucleotides, being the increase in lysozyme concentration of $93 \%$ for $A_{4} A, 119 \%$ for $U_{4} U$.

Another interesting molecule with bacteriostatic properties is 
Table 2

Summary of studies about Diquafosol application in the eye and their effects on different kinds of patients.

\begin{tabular}{|c|c|c|c|c|c|}
\hline Molecules & Parameters & Patients & Posology & Effect & Reference \\
\hline $\begin{array}{l}3 \% \text { Diquafosol vs. } 0.1 \% \\
\text { sodium hyaluronate }\end{array}$ & $\begin{array}{l}\text { Tear stability; } \\
\text { corneal integrity }\end{array}$ & Dry eye after cataract surgery & $\begin{array}{l}6 \text { times a day after } \\
\text { cataract surgery }\end{array}$ & $\begin{array}{l}\text { The Diquafosol group } \\
\text { showed significantly } \\
\text { superior TBUT } \\
(\mathrm{P}<0.001) \text {, corneal } \\
\text { fluorescein }(\mathrm{P}=0.045), \\
\text { and conjunctival } \\
\text { staining }(\mathrm{P}=0.001)\end{array}$ & (Park et al., 2015) \\
\hline 3\% Diquafosol & $\begin{array}{l}\text { Dry eye symptoms; } \\
\text { tear stability; } \\
\text { corneal integrity }\end{array}$ & $\begin{array}{l}\text { Dry eye (DE) patients wearing } \\
\text { contact lenses (CLs) or with } \\
\text { concomitant meibomian gland } \\
\text { dysfunction (MGD) or } \\
\text { conjunctivochalasis }\end{array}$ & Not described & $\begin{array}{l}\text { Significant } \\
\text { improvement in total } \\
\text { symptom score, corneal } \\
\text { and conjunctival } \\
\text { fluorescein staining } \\
\text { score, and tear film } \\
\text { break-up time }\end{array}$ & (Yamaguchi et al., 2015) \\
\hline $\begin{array}{l}\text { 3\% Diquafosol vs. } 0.1 \% \\
\text { sodium hyaluronate vs. } \\
\text { Saline solution }\end{array}$ & $\begin{array}{l}\text { tear stability; } \\
\text { corneal integrity }\end{array}$ & Normal eyes & Not described & $\begin{array}{l}3 \% \text { Diquafosol } \\
\text { significantly increased } \\
\text { TBUT for up to } 15 \mathrm{~min} \\
\text { after application }\end{array}$ & (Nam et al., 2015) \\
\hline 3\% Diquafosol & $\begin{array}{l}\text { Tear volume; Tear } \\
\text { stability }\end{array}$ & Sjögren Syndrome & 6 times a day & $\begin{array}{l}\text { The tear meniscus } \\
\text { radius and the tear film } \\
\text { breakup time were } \\
\text { significantly improved }\end{array}$ & (Yokoi et al., 2015) \\
\hline 3\% Diquafosol & Tear Volume & Contact lens wearers & Not described & $\begin{array}{l}\text { Tear Meniscus Heigth } \\
\text { significantly increased } \\
(P<0.05) \text { at } 5 \text { min, } \\
15 \text { min, } 30 \text { min, and } \\
60 \text { min compared with } \\
\text { the baseline values. }\end{array}$ & (Nagahara et al., 2015) \\
\hline 3\% Diquafosol & $\begin{array}{l}\text { Corneal surface } \\
\text { wetting }\end{array}$ & Cataract surgery & $\begin{array}{l}6 \text { times daily for } 4 \\
\text { weeks before surgery }\end{array}$ & $\begin{array}{l}\text { Diquafosol } 3.0 \% \\
\text { ophthalmic solution in } \\
\text { patients with senile } \\
\text { cataract was effective in } \\
\text { enhancing the } \\
\text { intraoperative corneal } \\
\text { surface wetting } \\
\text { property improving } \\
\text { optical clarity during } \\
\text { surgery. }\end{array}$ & (Miyake et al., 2014) \\
\hline $3 \%$ diquafosol & $\begin{array}{l}\text { Dry eye symptoms; } \\
\text { Visual quality; } \\
\text { corneal staining }\end{array}$ & $\begin{array}{l}\text { Dry eye after laser in situ } \\
\text { keratomileusis (LASIK) }\end{array}$ & 6 times daily & $\begin{array}{l}\text { Better staining and } \\
\text { symptomatology scores }\end{array}$ & (Mori et al., 2014) \\
\hline 3\% Diquafosol & $\begin{array}{l}\text { Dry eye symptoms; } \\
\text { tear stability }\end{array}$ & Aqueous-deficient dry eye & Not described & $\begin{array}{l}\text { Diquafosol ophthalmic } \\
\text { solution significantly } \\
\text { improved dry eye } \\
\text { symptoms, corneal } \\
\text { staining and BUT. }\end{array}$ & (Koh et al., 2014) \\
\hline $\begin{array}{l}0.3 \% \text { sodium hyaluronate } \\
\text { vs. } 3 \% \text { Diquafosol vs. } 2 \% \\
\text { rebamipide }\end{array}$ & $\begin{array}{l}\text { Optical quality } \\
\text { (high order } \\
\text { aberration and light } \\
\text { scattering) }\end{array}$ & Normal eyes & Not described & $\begin{array}{l}\text { A significant increasing } \\
\text { of High order } \\
\text { aberrration was found } \\
\text { for hyaluronate and } \\
\text { light scattering for } \\
\text { rebamipide compared } \\
\text { with Diquafosol }\end{array}$ & (Koh et al., 2013b) \\
\hline 3\% Diquafosol & $\begin{array}{l}\text { Lid margin } \\
\text { abnormalities; tear } \\
\text { volume; corneal } \\
\text { integrity }\end{array}$ & Meibomian gland dysfunction & 4 times a day & $\begin{array}{l}\text { Ocular symptoms, lid } \\
\text { margin abnormalities, } \\
\text { SPK score and meibum } \\
\text { grade were decreased. } \\
\text { Break-up time and tear } \\
\text { film meniscus were } \\
\text { increased }\end{array}$ & (Arita et al., 2013) \\
\hline $\begin{array}{l}\text { 1\% Diquafosol vs. } 3 \% \\
\text { Diquafosol }\end{array}$ & $\begin{array}{l}\text { Dry eye symptoms; } \\
\text { tear stability; } \\
\text { corneal integrity }\end{array}$ & Dry eye symdrome & 6 time a day & $\begin{array}{l}\text { Both concentrations } \\
\text { improved corneal } \\
\text { integrity and } \\
\text { symptomatology }\end{array}$ & (Matsumoto et al., 2012) \\
\hline $\begin{array}{l}0.1 \% \text { sodium } \\
\text { hyaluronate }+3 \% \\
\text { Diquafosol }\end{array}$ & $\begin{array}{l}\text { Dry eye symptoms; } \\
\text { tear volumne; tear } \\
\text { stability; cornreal } \\
\text { integrity }\end{array}$ & Dry eye symdrome & Not described & $\begin{array}{l}\text { When sodium } \\
\text { hyaluronate } \\
\text { monotherapy was } \\
\text { insufficient, Diquafosol } \\
\text { tetrasodium was } \\
\text { effective in improving } \\
\text { objective and } \\
\text { subjective symptoms }\end{array}$ & (Kamiya et al., 2012) \\
\hline
\end{tabular}


lactoferrin. Particularly, lactoferrin is an iron-binding protein, thus reducing the availability of iron necessary for microbial growth and survival. Additionally, the anti-inflammatory actions of this protein have also been proposed (Arnold et al., 1977; Conneely, 2001). The dinucleotide $\mathrm{Ap}_{4} \mathrm{~A}$ was able to increase lactoferrin concentration from $68 \pm 4 \mu \mathrm{g} / \mathrm{ml}$ to $83.17 \pm 9.89 \mu \mathrm{g} / \mathrm{ml}$ at $1 \mathrm{~h}$ of instillation. This effect was slightly increased at $2 \mathrm{~h}$ and continued for $2 \mathrm{~h}$ more until it returned to the baseline values (Loma et al., 2016).

The increasing of lysozyme and lactoferrin after dinucleotides instillation is mediated by purinergic receptors activation. The presence of different $\mathrm{P} 2 \mathrm{X}$ and $\mathrm{P} 2 \mathrm{Y}$ receptors on the ocular surface were noted. $\mathrm{Ap}_{4} \mathrm{~A}$ and $\mathrm{Up}_{4} \mathrm{U}$ mainly stimulate $\mathrm{P}_{2} \mathrm{Y}_{2}$, but $\mathrm{Ap}_{4} \mathrm{~A}$ can also act on $\mathrm{P} 2 \mathrm{X} 2, \mathrm{P} 2 \mathrm{X} 4, \mathrm{P}_{2} \mathrm{Y}_{1}$ and $\mathrm{P}_{2} \mathrm{Y}_{2}$ receptors. Previous studies showed that the tear secretion is stimulated with $\mathrm{Ap}_{4} \mathrm{~A}$ by $\mathrm{P}_{2} \mathrm{Y}_{2}$ receptors (Fonseca et al., 2015; Pintor et al., 2002a). The antagonists used in the study of lysozyme and the lack of effect of some nucleotides such as UDP and ADP (preferential agonists of $\mathrm{P}_{2} \mathrm{Y}_{6}$ and $\mathrm{P}_{2} \mathrm{Y}_{1}$ but also agonists of $\mathrm{P}_{2} \mathrm{Y}_{12}, \mathrm{P}_{2} \mathrm{Y}_{13}$ and $\mathrm{P}_{2} \mathrm{Y}_{14}$ ) (Ralevic and Burnstock, 1998) may suggest that $\mathrm{P}_{2} \mathrm{Y}_{2}$ is responsible for this, since only $\mathrm{P}_{2} \mathrm{Y}_{2}$ actions have been demonstrated on lysozyme production (Peral et al., 2008).

For lactoferrin, $\mathrm{Ap}_{4} \mathrm{~A}$ action was also mediated by purinergic receptors activation. Although the lacrymal gland is the major source of tear lactoferrin, it has been demonstrated that ocular surface epithelial cells also produce detectable amounts of lactoferrin (Flanagan and Willcox, 2009; Santagati et al., 2005) with higher expression in conjunctival than corneal epithelial tissue suggesting that activation of $\mathrm{P} 2$ receptors identified in these localizations could also be involved in lactoferrin secretion. The authors used some selective antagonist for $\mathrm{P}_{2} \mathrm{Y}_{1}, \mathrm{P} 2 \mathrm{X} 4$ and $\mathrm{P}_{2} \mathrm{Y}_{2}$, and they found that only AR-C118925XX (selective P2Y $\mathrm{Y}_{2}$ purinergic receptor antagonist) blocked the effect of $\mathrm{Ap}_{4} \mathrm{~A}$. Moreover, PPADS (antagonist of mainly $\mathrm{P} 2 \mathrm{X}$ but also $\mathrm{P}_{2} \mathrm{Y}_{1}$ receptors) was also tested to evaluate the activation of other $\mathrm{P} 2 \mathrm{X}$ receptors, and indeed it was able to partially reverse $\mathrm{Ap}_{4} \mathrm{~A}$ action. Altogether, it seems that the lactoferrin production is mainly triggered by $\mathrm{P}_{2} \mathrm{Y}_{2}$ purinergic receptor, but the participation of a $\mathrm{P} 2 \mathrm{X}$ and a $\mathrm{P}_{2} \mathrm{Y}_{1}$ receptor cannot be discarded.

Since both proteins, lysozyme and lactoferrin are the first defense mechanism against microbial infection, dinucleotides might provide additional protection by increasing the natural agents in tears of healthy subjects. Moreover, the increasing of these proteins could help to stabilize the tear film, avoiding an excessive tear evaporation rate and ocular surface desiccation. In particular, the lactoferrin diminishes the superficial tension of the tear film (Millar

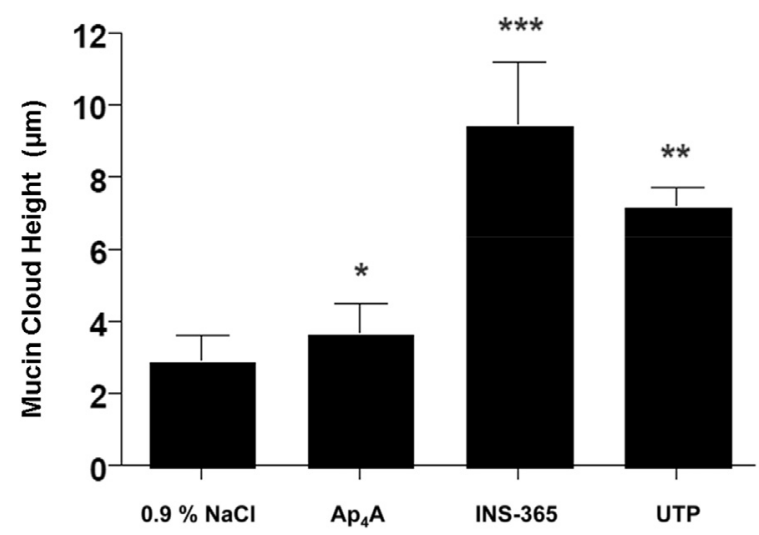

Fig. 9. Variations in mucin cloud height after dinucleotides and nucleotides (agonists $\mathbf{P 2 Y}_{2}$ ) treatment. Graph shows the significant increase on mucin cloud height in rabbits after the treatment with all nucleotides $\left(n=3\right.$, Tukey-Kramer test; ${ }^{*} p<0.05$, ${ }^{* *} p<0.01,{ }^{* * *} p<0.001$ ), which is maximal after INS-365 application being about 3-fold higher than control. Values represent means \pm SD.

et al., 2006; Tragoulias et al., 2005).

Other important molecules for tear film stability and homeostasis are the mucins. Mucins are high molecular weight glycoproteins that are produced by corneal and conjunctival epithelial cells present in the ocular surface (Murube, 2012). There are three families of ocular mucins based on their amino acid sequence: transmembrane (MUC1, MUC3A, MUC3B, MUC4, MUC12, MUC13, MUC15, MUC16, MUC17, MUC20, and MUC21), secreted gelforming (MUC2, MUC5AC, MUC5B, MUC6, and MUC19) and secreted soluble mucins (MUC7 and MUC9). Other mucins such as MUC8 and MUC11 have not been classified yet (Corrales et al., 2011; Murube, 2012).

The main actions of mucins are to clean, lubricate and protect the ocular surface from adverse environmental conditions (Mantelli and Argueso, 2008; Murube, 2012).

Based on the response elicited by UTP and ATP on isolated human and rabbit conjunctivas, Jumblatt and Jumblatt suggested the involvement of $\mathrm{P}_{2} \mathrm{Y}_{2}$ purinergic receptors in mucin secretion (Jumblatt and Jumblatt, 1998). Moreover, Murakami et al. showed that the UTP/ATP- mediated mucin secretagogue effect was reversed in rabbits pre-treated with suramin (Murakami et al., 2003). The antagonist suramin blocks all P2Y receptors with the exception of the $\mathrm{P}_{2} \mathrm{Y}_{4}$ receptor (von Kugelgen, 2006). Thus, and taking into account that $\mathrm{P}_{2} \mathrm{Y}_{2}$ receptor is expressed in the
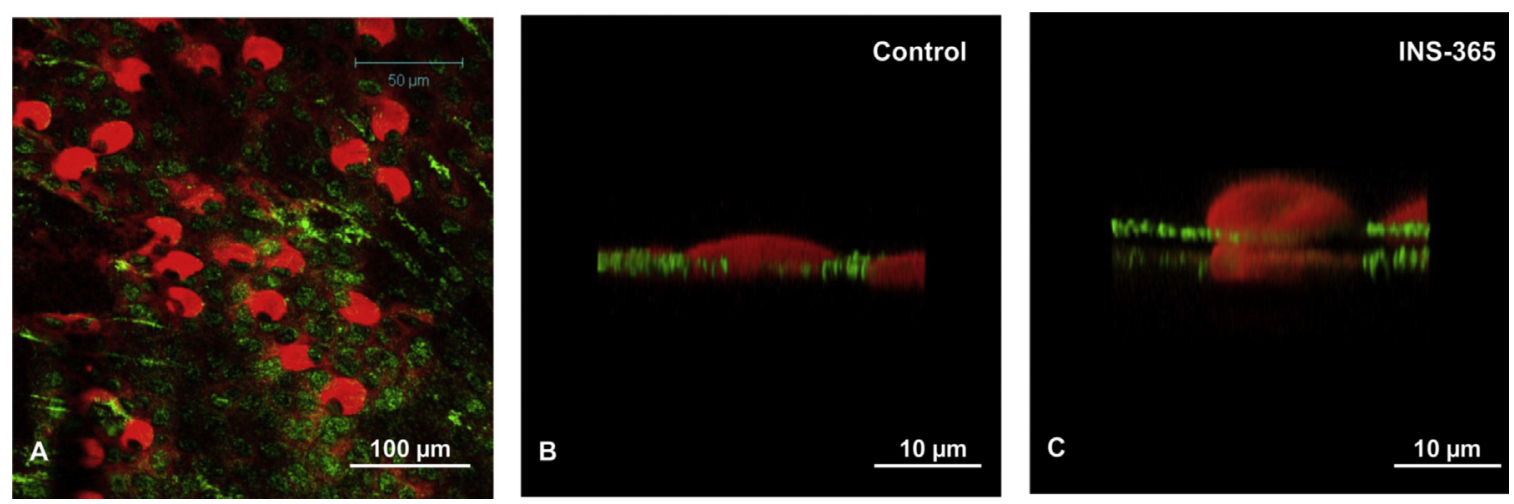

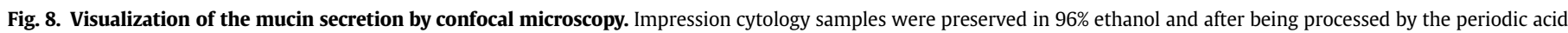

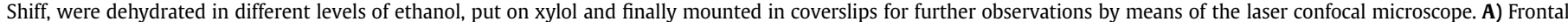

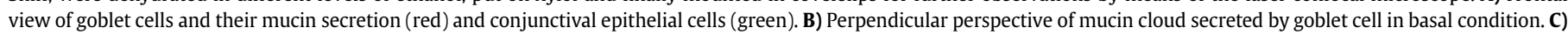
Perpendicular view of mucin cloud after INS-365 treatment. 
conjunctival epithelium of rabbits and monkeys (Cowlen et al., 2003), it has been considered that the $\mathrm{P}_{2} \mathrm{Y}_{2}$ receptor governs the conjunctival mucin secretion. Both $\mathrm{Ap}_{4} \mathrm{~A}$ and $\mathrm{Up}_{4} \mathrm{U}$ are agonists of $\mathrm{P}_{2} \mathrm{Y}_{2}$ receptor so they should promote the mucin secretion from conjunctival Goblet cells.

The first study on dinucleotides and mucin secretion in tears was published in 2001 (Fujihara et al., 2001). They found that INS365, aka $U_{4} U$ and also termed diquafosol (see section 2.1.7), has the ability to evoke mucin secretion on In vivo conjunctivas of a rat dry eye model. In 2004 they corroborated their results in the New Zealand white rabbit model (Pintor et al., 2004a). They concluded that INS365 restored moisture and hydration of the ocular surface of rats by its effects on tear and mucin secretion. Other authors have found the same effect of INS-365 in different animal models, increasing Goblet cell Density and mucin production (Fujihara et al., 2002; Kojima et al., 2014; Terakado et al., 2014).

Our research group performed a study to evaluate the possible involvement of other $\mathrm{P} 2 \mathrm{Y}$ receptors, not only $\mathrm{P}_{2} \mathrm{Y}_{2}$, such as $\mathrm{P}_{2} \mathrm{Y}_{4}$ and $\mathrm{P}_{2} \mathrm{Y}_{6}$ in rabbit conjunctival mucin secretion, testing the mucin secretagogue effect of the dinucleotide $\mathrm{Ap}_{4} \mathrm{~A}$ and INS-365. The technique used for ocular mucin visualization was confocal laser scanning microscopy (Fig. 8). This technique, following the protocol stablished by Peral and Pintor, allows us to measure mucin cloud height $(\mathrm{MCH})$ over the goblet cell. In this sense, all the dinucleotides tested evoked a significant increase of the $\mathrm{MCH}$ parameter in comparison with control animals. The rank order of effect on mucin secretion was INS-365 $(\mathrm{MCH}=9.50 \pm 1.72 \mu \mathrm{m})$ greater than UTP $(\mathrm{MCH}=6.50 \pm 0.49 \mu \mathrm{m})$ and greater than $\mathrm{Ap}_{4} \mathrm{~A}$ $(\mathrm{MCH}=3.75 \pm 0.79 \mu \mathrm{m})$, Fig. 9 .

It was also observed that the secretory effect of INS-365 and UTP was more robust than that obtained by $\mathrm{Ap}_{4} \mathrm{~A}$. This fact suggests the involvement not only of $\mathrm{P}_{2} \mathrm{Y}_{2}$ receptors but also of other uracil nucleotide-sensitive receptors. To determine the possible purinoceptors involved in mucin secretion RB-2, suramin and PPADS antagonists were applied on rabbit conjunctiva in the presence or absence of INS-365. RB-2 was the most effective purinoceptor antagonist, reducing INS365-evoked MCH by 3.5-fold (MCH RB$2+$ INS365 $=3.18 \pm 0.83 \mu \mathrm{m}$ versus $\mathrm{MCH}$ INS$365=11.20 \pm 0.37 \mu \mathrm{m})$. Suramin and PPADS also reduced the MCH value in comparison with rabbits treated with INS365 alone, but they were less effective. Taking into account that RB-2 is a very weak antagonist of $\mathrm{P}_{2} \mathrm{Y}_{2}$ receptors, a modest antagonist of $\mathrm{P}_{2} \mathrm{Y}_{4}$ receptors and a potent antagonist of $\mathrm{P}_{2} \mathrm{Y}_{6}$ receptors (Abbracchio and Ceruti, 2006; von Kugelgen, 2006), it seems that $\mathrm{P}_{2} \mathrm{Y}_{6}$, and to a lesser extent $\mathrm{P}_{2} \mathrm{Y}_{4}$ receptors, play an important role in rabbit conjunctival mucin secretion.

There is only one study regarding INS-365 (Diquafosol) and mucin production in human conjunctiva epithelium. Sigheyasu et al. related a significant increase of sialic acid concentration, a good marker for evaluating mucins in biological samples (Shigeyasu et al., 2015a, 2015b), in tears after Diquafosol instillation in healthy human eyes. This finding corroborates the data described in animal model by other authors (Fujihara et al., 2002; Kojima et al., 2014; Terakado et al., 2014).

\subsubsection{Contact lens delivery of dinucleoside polyphosphates}

The most common system to treat ocular conditions is by applying eye drops (Kojima et al., 2008; McCann et al., 2012). Sometimes, the use of punctal plugs are necessary to increase the resident time of the active molecule on the ocular surface (Karcioglu and Fleming, 2008). Probably the major challenge to treating ocular pathologies, including surface disease such as dry eye, is to enhance the bioavailability, reduced by the complex structure of the ocular surface. In this context, contact lenses have been proposed as new vehicle for drug delivery. Contact lenses are separated from the cornea by a thin fluid layer called post-lens tear film. The clearance time of the post-lens tear film in soft contact lenses is about $30 \mathrm{~min}$ (McNamara et al., 1999). Thus, ophthalmic drugs released from the contact lenses will have a residence time in front of the cornea for at least $30 \mathrm{~min}$ compared to 2 min for eye drops. This method is currently being investigated to deliver molecules as anti-inflammatory, antibiotics or lubricants molecules on the ocular surface. In the case of dinucleotides, contact lens delivery system has been used with $\mathrm{Ap}_{4} \mathrm{~A}$ to improve the secretagogue function of this molecule.

For experiments, two materials of hydrophilic contact lenses (Omafilcon A and Ocufilcon A) and another two materials of hydrogel-silicone contact lenses (Comfilcon A and Balafilcon A) were used. All lenses were uploaded with $1 \mathrm{mM} \mathrm{Ap} 4 \mathrm{~A}$ solution. In vitro experiments showed that dinucleotide delivery from contact lens was more prolonged with non-ionic material (Omaficon $A$ and Comfilcon A) than ionic material Ocufilcon A and Balafilcon A). Moreover, the delivery rate was better in hydrogel-silicone lenses than hydrophilic lenses. In vivo experiments reported that $\mathrm{Ap}_{4} \mathrm{~A}$ delivery from non-ionic hydrogel-silicone contact lens was able to induce tear secretion higher than baseline values during $360 \mathrm{~min}$ (Dominguez-Godinez et al., 2013). It seems that the ionic charge of the contact lens materials could be the major factor in $A_{4} A$ delivery. In this sense, it is important to note that $\mathrm{Ap}_{4} \mathrm{~A}$ is a dinucleotide presenting four phosphates that in neutral $\mathrm{pH}$ present four negative charges (Patane et al., 2011). This could be the reason why those lenses with ionic charge, which is also negative, may repel $\mathrm{Ap}_{4} \mathrm{~A}$ and the molecule delivery is faster.

\subsubsection{Effect on corneal wound healing}

The corneal epithelium are in permanent renovation, being complete every 7-10 days (Liu and Kao, 2015). The proliferation and differentiation of limbal cells are responsible for the epithelium renovation. The new epithelial cells come to the mitotic activity of limbal basal cells which replace the old epithelial cells following a centripetal and superficial movement (Lemp and Mathers, 1989). When the epithelium is damaged, the reepithelization process or wound healing begins, following three phases: latency phase, migration phase and cell mitosis (Suzuki et al., 2003).

There is cell reorganization during the latency phase. The synthesis cytoskeletal proteins, such as actine, vinculin and taline, and ocular surface glycoproteins begins in this phase to act in the migration phase. Moreover, the wound area increases in this phase due to the action of some leucocytes from the tear film, eliminating necrotic cells (Panjwani et al., 1990; Suzuki et al., 2003). The migration phase mainly depends on actin filaments activation and other proteins to promote the movement of the cells from the periphery to the wound centre (Kurpakus et al., 1999). Finally, the cell division phase completes the wound healing process (Lehrer et al., 1998).

It has been described that some molecules released from the corneal nerves stimulate the wound healing process after ocular surface injuries (Muller et al., 2003). Among natural substances, nucleotides and dinucleotides present in tears have been shown to be very active to modify the rate of healing (Bowman and Green, 1981; Pintor et al., 2004a). Experiments performed in our laboratory on an animal model, demonstrated that the levels of $\mathrm{Ap}_{4} \mathrm{~A}$ and $\mathrm{Ap}_{5} \mathrm{~A}$ are significantly reduced after the damage, recovering after $10 \mathrm{~h}$. The same ratio of $\mathrm{Ap}_{4} \mathrm{~A} / \mathrm{Ap}_{5} \mathrm{~A}$ concentration in tears remained stable. This means that diadenosine polyphosphates remain low during the latency phase and recover during the migration phase, suggesting their involvement in the migration process (Mediero et al., 2006).

Nucleotides influence the corneal epithelial cells healing rate by either accelerating or decelerating the healing process. Pintor et al. 
found that the estimated healing time was for saline, $\mathrm{Ap}_{3} \mathrm{~A}, \mathrm{Ap}_{4} \mathrm{~A}$ and $A_{5} A$ were $32.2 \pm 2.0 \mathrm{~h}, 35 \pm 2.6 \mathrm{~h}, 26.0 \pm 0.6 \mathrm{~h}$ and $29.2 \pm 2.2 \mathrm{~h}$, respectively. It means that only diadenosine tetraphosphate provokes an increase in the wound healing rate (Pintor et al., 2004a). Based on these results, Mediero et al. evaluated the role of diadenosine polyphosphate in the epithelial cell migration, performed in primary corneal epithelial cell culture (Mediero et al., 2006). $\mathrm{Ap}_{4} \mathrm{~A}$ accelerate $5 \mathrm{~h}$ the wound healing whereas $\mathrm{Ap}_{3} \mathrm{~A}$ and $\mathrm{Ap}_{5} \mathrm{~A}$ delayed it $6.5 \mathrm{~h}$ and $10 \mathrm{~h}$ respectively. The opposite effects may be justified by the activation of different P2Y receptors subtypes present in the ocular surface (Klepeis et al., 2004; Weinger et al., 2005). Both $\mathrm{Ap}_{3} \mathrm{~A}$ and $\mathrm{Ap}_{5} \mathrm{~A}$ are agonist of $\mathrm{P}_{2} \mathrm{Y}_{6}$ and $\mathrm{Ap}_{4} \mathrm{~A}$ of $\mathrm{P} 2 \mathrm{Y}_{2}$. So, it seems that $\mathrm{P}_{2} \mathrm{Y}_{2}$ receptor stimulates the wound healing process and $\mathrm{P}_{2} \mathrm{Y}_{6}$ inhibits it.

Due to there not being a selective agonist for $\mathrm{P}_{2} \mathrm{Y}_{2}$ receptor, its implication in epithelial wound healing has been studied by silencing it with small interference RNA (siRNA) against the rabbit $\mathrm{P}_{2} \mathrm{Y}_{2}$ receptor. The authors performed In vitro and In vivo migration analysis showed that the silencing process reduced the corneal cells migration when $\mathrm{Ap}_{4} \mathrm{~A}$ was instilled, even showing less wound healing than control group (without $\mathrm{Ap}_{4} \mathrm{~A}$ instillation). It seems to demonstrate the effect on wound healing of the natural $\mathrm{Ap}_{4} \mathrm{~A}$ in tears, mediated by $\mathrm{P}_{2} \mathrm{Y}_{2}$ (Crooke et al., 2009). Moreover the involvement of the $\mathrm{P}_{2} \mathrm{Y}_{2}$ receptor has been demonstrated by other authors (Boucher et al., 2010; Sanderson et al., 2014). Mediero et al. demonstrated that the activation of the $\mathrm{P}_{2} \mathrm{Y}_{2}$ receptor with $\mathrm{Ap}_{4} \mathrm{~A}$, accelerates corneal epithelial cell migration during wound healing with the activation of mitogen-activated protein kinase (MAPK) and cytoskeleton pathways, whereas activation of the $\mathrm{Ap}_{3} \mathrm{~A} / \mathrm{P}_{2} \mathrm{Y}_{6}$ receptor signals only the MAPK pathway (Mediero et al., 2008). Moreover, phospholipase C/Protein Kinase C (PLC/PKC) pathway in the activation of ERK1/2 and ROCK-I is involved (Mediero et al., 2011).

\subsubsection{Effect on epithelial permeability}

Corneal permeability has also been studied under the dinucleotides application. Eye diseases are often treated by topically administered drugs. However, as commented in section 2.1.9, ocular drug delivery is strongly limited by the barriers of the eye resulting in poor drug bioavailability (Kompella et al., 2010). The cornea is a chemical and mechanical barrier that stops the entry of any foreign body, included drugs, to the anterior chamber (Leong and Tong, 2015). The corneal epithelium is the layer with a stronger barrier function (Gobbels et al., 1990; McNamara et al., 1997; Yokoi and Kinoshita, 1995), meanwhile the stroma and endothelium give less resistance to transcorneal permeability (Huang et al., 1983, 1989).

Fujihara et al. evaluated the corneal barrier function with a modified anterior fluorometer measuring fluorescein penetrance (Fujihara et al., 2001). They found that INS-365 as low as 1\% decreases the dye penetrance approximately by $50 \%$. They suggested that this action was mediated by $\mathrm{P}_{2} \mathrm{Y}_{2}$ but they did not test the implication of this metabotropic receptor.

The involvement and the effect on corneal permeability mediated by $\mathrm{P}_{2} \mathrm{Y}_{2}$ receptors have been quite different when studied by other authors. By means of the transepithelial electrical resistance (TEER) it has been possible to demonstrate that the dinucleotide $\mathrm{Ap}_{4} \mathrm{~A}$ is able to open the paracellular corneal epithelial barrier being the effect transitory and maximal $2 \mathrm{~h}$ after the application of the dinucleotide (Loma et al., 2015b). This is an interesting function of $\mathrm{Ap}_{4} \mathrm{~A}$ because its topical application could "open the door" to other compounds to treat internal ocular pathologies such as glaucoma or intraocular infections.

The possibility of facilitating the paracellular way for the delivery of compounds within the eye presents two main advantages: first, to increase the effect with less concentration of the drug and concomitantly and second less adverse events In this way, $A_{4} A$ administration showed that, when it was topically applied two hours before the application of a classical adrenergic compounds for glaucoma treatment, the concentrations of brimonidine and timolol in the aqueous humour increased from $64.3 \pm 5.3 \mathrm{nM}$ to $240.6 \pm 8.6 \mathrm{nM}$ and from $58.9 \pm 9.2 \mathrm{nM}$ to $183.7 \pm 6.8 \mathrm{nM}$ respectively, and this also produced a more robust reduction in IOP than when they are applied alone (Loma et al., 2015a).

Diadenosine tetraphosphate effect is produced by the temporary disruption of the tight junctions present in the corneal epithelium (Loma et al., 2015b). These tight-junctions form an epithelial junctional complex with the adherens junctions and desmosomes to avoid the entry of substances within the eye (Ban et al., 2003). Tight junctions are multifunctional and dynamic protein complexes that connect adjacent cells by sealing the intercellular space between cells preventing the paracellular movement of solutes, ions and water. The main proteins forming a tight junction in the cornea are occludin (Langbein et al., 2002), claudins (Ban et al., 2003) and zonula occludens-1 (ZO-1) (Ban et al., 2003; Sosnova-Netukova et al., 2007; Yoshida et al., 2009). It was possible to measure the effect of $\mathrm{Ap}_{4} \mathrm{~A}$ on tight junction proteins by western blot and the three mentioned proteins, claudin, occludin-7 and ZO-1, showed a clear reduction in its expression $2 \mathrm{~h}$ after the dinucleotide application, the fall of expression being 59.3\% for ZO-1, 57.9\% for occludin-7 and 58.8\% for claudin (Loma et al., 2015b).

The implication of $\mathrm{P}_{2} \mathrm{Y}_{2}$ in $\mathrm{Ap}_{4} \mathrm{~A}$ in the mentioned effect was also demonstrated. An elegant approach to demonstrate the importance of this receptor on the $\mathrm{Ap}_{4} \mathrm{~A}$ effect on corneal barrier was performed by using $\mathrm{P}_{2} \mathrm{Y}_{2}$ receptor siRNAs. Silencing the $\mathrm{P}_{2} \mathrm{Y}_{2}$ receptor completely abolished the effect of drug delivery carried out by $\mathrm{Ap}_{4} \mathrm{~A}$. Moreover, the proteins that form the commented tightjuntions remained unaltered in the presence of the dinucleotide. As happens in the $\mathrm{Ap}_{4} \mathrm{~A}$ wound healing stimulation, the effect of $\mathrm{Ap}_{4} \mathrm{~A}$ was mediated by $\mathrm{P}_{2} \mathrm{Y}_{2}$ activation coupled with ERK1/2 pathway (Loma et al., 2015b).

\subsection{Dinucleoside polyphosphates in the anterior pole}

\subsubsection{Presence in the aqueous humour}

Aqueous humour, the secretion that nourishes the avascular structures of the eye such as cornea and lens, contains dinucleoside polyphosphates at low micromolar concentration (Castany et al., 2011; Pintor et al., 2003). Among the different dinucleotides, Pintor and colleagues have identified and quantified the presence of $\mathrm{Ap}_{4} \mathrm{~A}(0.34 \mathrm{mM})$ and $\mathrm{Ap}_{5} \mathrm{~A}(0.08 \mathrm{mM})$ in the aqueous humour of rabbits (Pintor et al., 2003). These compounds are also present in the aqueous humour of human, with levels of $0.020 \mathrm{mM}$ (for $\mathrm{Ap}_{4} \mathrm{~A}$ ) and $0.021 \mathrm{mM}$ (for $\mathrm{Ap}_{5} \mathrm{~A}$ ) (Castany et al., 2011). Moreover, in glaucoma patients, $\mathrm{Ap}_{4} \mathrm{~A}$ concentration is 15 times higher than in normal individuals (Castany et al., 2011).

The origin of the dinucleotides in aqueous humour has only recently been elucidated as a mechanism dependent of the ciliary body epithelium although some clues about their extracellular origin were suggested some years ago (Pintor et al., 2003). In the case of nucleotides such as ATP, Mitchell and colleagues have demonstrated its direct release from ciliary epithelial cells in culture (Mitchell et al., 1998).

A key point in the release of nucleotides to the aqueous humour is the TRPV4 channel described as ciliary body epithelial cells which indeed mediates in the release of different substances to the aqueous humour (Alkozi and Pintor, 2015). In this sense, either by producing osmotic changes, which is one of the main features of this TRPV channel, or by using selective agonists such as 
GSK1016790a, it has been seen that the amount of diadenosine tetraphosphate almost triplicates its extracellular concentration (Pintor et al., 2011). The mechanism of such release is mostly carried out by pannexins (pannexin 1) in a percentage of $40 \%$, the same percentage with connexins and finally $20 \%$ by exocytosis (Pintor et al., 2011). The molecular mechanisms that connect TRPV4 with pannexin and connexons are still under investigation, since the exocytosis may be explained by the typical $\mathrm{Ca}^{2+}$ entry produced when the TRPV4 channel is activated.

In general, the activation of a TRPV4 channel is relevant since changes in the hydrostatic and osmotic pressure, typical in many types of glaucoma, may respond to such variations in the aqueous humour dinucleotide concentration. Nevertheless, it is important to note that another important structure which may contribute to the release of nucleotides and dinucleotides to the aqueous humour, is the lens. Several studies have reported that in this structure the release of nucleotides such as ATP is also performed by means of a TRPV4 and via mechanisms that involve the participation of hemichannels (Shahidullah et al., 2012a, 2012b).

The presence of the compounds $\mathrm{Ap}_{3} \mathrm{~A}$ (Szwergold and Lal, 2005) and $\mathrm{Ap}_{4} \mathrm{~A}$ as well as the release of the latter, has been demonstrated in mice. Interestingly, the release of the mentioned substance varies depending on the mice strain used. The strains FVB and C57, release equivalent amounts of $\mathrm{Ap}_{4} \mathrm{~A}$ providing concentrations of about $1.3 \mathrm{nM}$, while in the glaucomatous mice, $\mathrm{DBA} / 2 \mathrm{~J}$, the concentration of $\mathrm{Ap}_{4} \mathrm{~A}$ is $5.9 \mathrm{nM}$. Indeed, the changes in the aqueous humour, making it more hypoosmotic, despite affecting the three mice strains, was particularly remarkable in the DBA/2J glaucomatous animal when the levels increased to $61 \mathrm{nM}$. It seems, therefore, that the lens presents a very relevant role in the release of nucleotides to the aqueous humour and particularly in models of glaucoma as indicated. The ability of the lens to release nucleotides is probably due to its enormous concentrations of nucleotides, being the tissue with higher nucleotide levels in the whole body (Pintor, 2011). It is interesting to notice that nucleotides, apart from developing the tasks of keeping the pumps and transporters, operative, nucleotides and dinucleotides develop a physical action avoiding the entry of some UV wavelengths to the retina by absorbing this damaging light (Pintor, 2011).

The concentration, and thereby function, of $A_{4} A$ and $A_{5} A$ in the aqueous humour can also be controlled by ecto-nucleotidases. Corneal endothelial cells express NTPDase 1 isoform as well as eN enzymes (Gomes et al., 2005). Additionally, non-pigmented ciliary epithelial cells and ciliary stromal cells (endothelial and interstitial cells) express ENPP1, NTPD1 and eN/5NTE (Braun, 2010; Farahbakhsh, 2003). On the other hand, trabecular meshwork cells express ENPP1-3, NTPD2 as well as NTPD8 and 5NTE (Li et al., 2011). Since all these structures bathed by aqueous humour also present purinergic receptors, dinucleotides and their metabolites (i.e. ATP, ADP and adenosine) can regulate their physiological functions including corneal endothelial fluid transport, aqueous fluid production and drainage (Crooke et al., 2008).

\subsubsection{Effect on intraocular pressure}

2.2.2.1. General effects. The intraocular pressure (IOP), which maintains the spherical shape of the eye, depends on the balance between the aqueous humour production and its drainage (Goel et al., 2010). Aqueous humour is secreted by the ciliary processes of the ciliary body and is drained, mainly, through the trabecular meshwork into the canal of Schlemm (Goel et al., 2010). Since both structures express nucleotide receptors (Crooke et al., 2008; Guzman-Aranguez et al., 2013), dinucleotides but also their metabolites could regulate aqueous humour secretion/drainage and thereby modify IOP. Some dinucleotides such as the diinosine polyphosphates can also regulate IOP. Guzman-Aranguez and colleagues have described the ability of diinosine pentaphosphate (Ip5I) to increase IOP in normotensive rabbits (Guzman-Aranguez et al., 2012). Conversely, diinosine triphosphate (Ip3I) and diinosine tetraphosphate (Ip4I) reduce IOP, the latter being the more potent hypotensive compound (Guzman-Aranguez et al., 2012).

Indeed, the topical application of $\mathrm{Ap}_{4} \mathrm{~A}$ in normotensive rabbits reduces IOP in a concentration dependent manner (Pintor et al., 2003). Conversely, $\mathrm{Ap}_{5} \mathrm{~A}$ (also present in aqueous humour), $\mathrm{Ap}_{2} \mathrm{~A}$ and $A_{3} A$ increase the IOP of these animals (Pintor et al., 2003). Although the topical application of diadenosine tetraphosphate on animal models is the reduction of IOP, studying the effects on the main ocular structures responsible for the aqueous humour dynamics, trabecular meshwork and ciliary body, the effects are the opposite. While in the trabecular meshwork $\mathrm{Ap}_{4} \mathrm{~A}$ produces facilitation in the aqueous humour drainage, in the ciliary body this dinucleotide produces an increase in aqueous humour production.

2.2.2.2. Effect on the trabecular meshwork. Trabecular meshwork presents many $\mathrm{P} 2 \mathrm{Y}$ receptors, mainly $\mathrm{P}_{2} \mathrm{Y}_{1}, \mathrm{P}_{2} \mathrm{Y}_{2}$, and $\mathrm{P}_{2} \mathrm{Y}_{4}$ in bovine TM cells (Soto et al., 2005) and $\mathrm{P}_{2} \mathrm{Y}_{11}$ in a cellular line of human trabecular meshwork (Crosson et al., 2004). Diadenosine polyphosphates do not activate all these receptors in the same way. For instance, $\mathrm{Ap}_{3} \mathrm{~A}$ and $\mathrm{Ap}_{4} \mathrm{~A}$ can mainly activate $\mathrm{P}_{2} \mathrm{Y}_{1}$ (Schachter et al., 1996) receptors, nevertheless it is important to note that $\mathrm{Ap}_{4} \mathrm{~A}$ is also able to trigger $\mathrm{P}_{2} \mathrm{Y}_{2}$ and $\mathrm{P}_{2} \mathrm{Y}_{4}$ receptors (Lazarowski et al., 1995). Indeed, the application of $\mathrm{Ap}_{3} \mathrm{~A}$ and $\mathrm{Ap}_{4} \mathrm{~A}$ increased outflow facility at low micromolar concentrations (Soto et al., 2005), thereby contributing to the reduction in IOP previously detected in other animal models (Pintor, 2005). The application of diadenosine polyphosphates in trabecular meshwork cells produces an increment in the intracellular $\mathrm{Ca}^{2+}$, but only in pharmacological studies, carried out by means of different mono and dinucleotide concentrations, as well as the use antagonists, permitted to identify which is responsible for the facilitation of outflow and $\mathrm{Ca}^{2+}$ mobilization. In this sense, the $\mathrm{P}_{2} \mathrm{Y}_{1}$ receptor agonist 2-MeS-ATP, together with $\mathrm{Ap}_{3} \mathrm{~A}$ and $\mathrm{Ap}_{4} \mathrm{~A}$, suggests that this is the main P2Y receptor involved in the mentioned effects. Moreover, the blockade obtained by the $\mathrm{P}_{2} \mathrm{Y}_{1}$ selective antagonist MRS-2179 on the drainage facilitation induced by $\operatorname{Ap}_{4} A$, and the sharp inhibition in the $\mathrm{Ca}^{2+}$ increases, as previously commented, confirms that this is the main receptor responsible for the reduction of IOP at the trabecular meshwork (Pintor, 2005).

2.2.2.3. Effects on the ciliary body. Some of the first actions where the effects of nucleotides and dinucleotides were detected in the ciliary body demonstrated the presence of $\mathrm{P} 2 \mathrm{X} 2$ receptors in the ciliary muscle (Peral et al., 2009). In this location and by means of the same ionotropic receptor, diadenosine tetraphosphate exerts the same actions other mononucleotides do. Interestingly, the action of $A_{4} A$, seems to occur on the cholinergic terminals innervating the ciliary muscle. These terminals after the activation of the dinucleotide promote the release of acetylcholine that contracts the muscle via muscarinic receptors. This contraction pulls the scleral spur opening the irido-corneal angle and therefore facilitating the evacuation of the aqueous humour by the trabecular meshwork (Pintor, 2005).

In a clear difference to what was described previously, other actions of diadenosine polyphosphates, mainly $\mathrm{Ap}_{4} \mathrm{~A}$ are mediated by $\mathrm{P}_{2} \mathrm{Y}_{2}$ receptors present in the ciliary epithelium (Martin-Gil et al., 2012). The presence of this receptor and its activation produces an effect which is opposite to the one observed in the ciliary muscle and in the trabeculum. In the ciliary body the activation of this receptor with dinucleotides or mononucleotides (selective for the $\mathrm{P}_{2} \mathrm{Y}_{2}$ receptor) produces a rise in IOP. This effect can be demonstrated when the $\mathrm{P}_{2} \mathrm{Y}_{2}$ receptor is silenced by means of a 


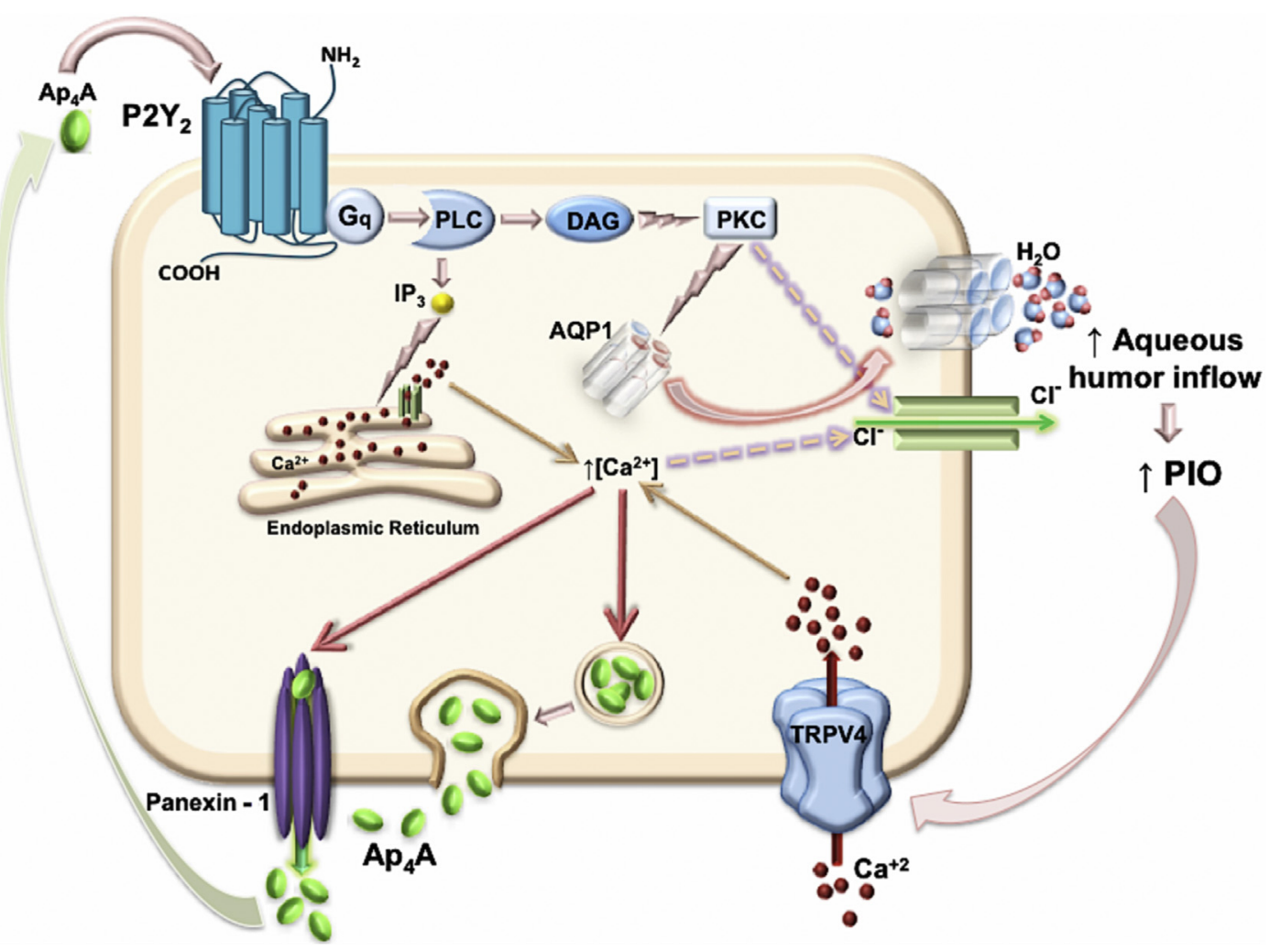

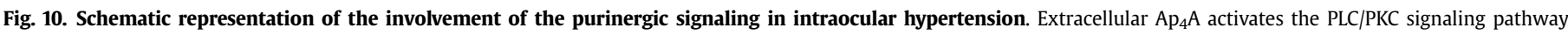

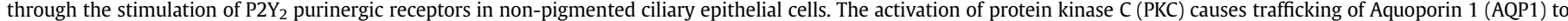

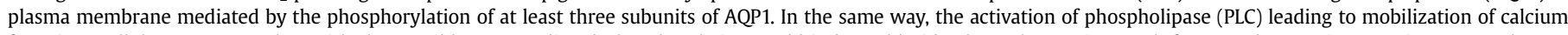

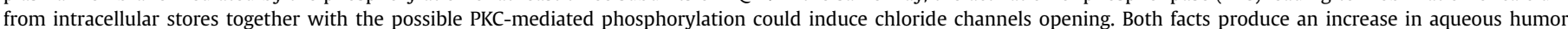

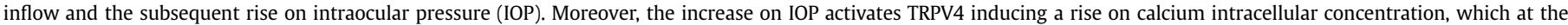
same time produces the $\mathrm{Ap}_{4} \mathrm{~A}$ release mainly through pannexin 1 and in lesser extent by vesicular exocytosis feeding back this process.

siRNA, and in this case the lack of expression of this receptor produces a profound and long-lasting reduction in IOP (Martin-Gil et al., 2012).

The mechanism by which $\mathrm{P}_{2} \mathrm{Y}_{2}$ receptor stimulated by $\mathrm{Ap}_{4} \mathrm{~A}$ produces it effect seems to be a combination of several cellular mechanisms. It has been observed in non-pigmented ciliary epithelial cells that the activation of the $\mathrm{P}_{2} \mathrm{Y}_{2}$ receptor increases the traffic of aquaporin 1 (AQ1) from intracellular stores to the plasma membrane (Martin-Gil and Pintor, 2010; Pintor, 2010). This effect should be a consequence of the activation of the canonical pathway, which triggers PKC activation (Guzman-Aranguez and Pintor, 2012). The mobilization of AQ1 triggered by $A_{4} A$, was able to mobilize AQP1 which was time dependent, the maximal expression in the cell membranes occurring $1 \mathrm{~h}$ after the application of the dinucleotide and returning to initial values in two hours' time (Martin-Gil and Pintor, 2010). Unpublished results performed in our laboratory, demonstrated that apart from AQ1 trafficking there was a net flow of $\mathrm{Cl}^{-}$from ciliary epithelial cells, this ion being responsible for aqueous humour secretion. In other cellular models, achondroplastic chondrocytes, the effect of $\mathrm{Ap}_{4} \mathrm{~A}$ was virtually identical. In this model, diadenosine tetraphosphate was also facilitating the efflux of chloride from these cells (Huete et al., 2011). Therefore, it seems that there is a coordinated action triggered by the $\mathrm{P}_{2} \mathrm{Y}_{2}$ receptor after the stimulation by $\mathrm{Ap}_{4} \mathrm{~A}$ that produces a mobilization of AQ1 towards the membrane and an increase in the $\mathrm{Cl}^{-}$efflux, which altogether, would be responsible for the $\mathrm{P}_{2} \mathrm{Y}_{2}$ mediated elevation of IOP (Fig. 10).

\subsubsection{Putative actions of dinucleotides in the lens}

There are no studies in the literature investigating the role of dinucleotides in the lens. Therefore, a possibility is to suggest some of the possible effects, just by checking on the $\mathrm{P} 2$ receptors present in the lens that are suitable for stimulation by dinucleoside polyphosphates.

The lens epithelium can respond to the changes in the concentration of dinucleotides found in the aqueous humour as previously described. The identification of P2Y receptors ( $\mathrm{P}_{2} \mathrm{Y}_{1}$ and $\mathrm{P}_{2} \mathrm{Y}_{2}$ ) by RT-PCR and in situ hybridization in the lens has been described (Cowlen et al., 2003; Hu et al., 2008; Merriman-Smith et al., 1998). Because $\mathrm{Ap}_{4} \mathrm{~A}$ is most representative of the dinucleotide in the aqueous humour, and its ability is known to stimulate both receptors, changes in $\mathrm{Ap}_{4} \mathrm{~A}$ concentration could alter intracellular $\mathrm{Ca}^{2+}$ concentration in cortical lens fibers. Moreover, calcium mobilization in the lens could modulate the activity of different $\mathrm{K}+$ channels (Rhodes et al., 2003), which will determine the membrane potential of the lens, and subsequently the $\mathrm{Cl}^{-}$ channels that contribute to lens volume regulation and transparency (Valverde et al., 1992).

\subsubsection{Neuroprotective role in the ciliary body}

The neuroprotective effect of $\mathrm{Ap}_{4} \mathrm{~A}$ is closely related to the fact that this dinucleotide is stored in synaptic vesicles together with different classical neurotransmitters (Miras-Portugal et al., 1998). In this sense, apart from its roles inhibiting the epileptiform activity and synaptic potentials in the hippocampus (Klishin et al., 1994; Ross et al., 1999) and inhibition of glutamate release in the striatum (Oaknin et al., 2001) or the stimulation of locus coeruleus, 
producing excitation (Frohlich et al., 1996), this dinucleotide can present interesting properties protecting the nervous system from damage.

Studies performed at the CNS have demonstrated that $\mathrm{Ap}_{4} \mathrm{~A}$ can give protection from the neurodegeneration induced by methylamphetamine either in In vitro or in In vivo experiments (Harvey et al., 2009). This protective effect also exists when cerebral ischemia exists or when sympathetic terminals are chemically damaged by means of 6-OH-dopamine (Wang et al., 2003).

Neurodegenerative diseases like Alzheimer's disease or Parkinson's, can affect, of course the CNS, but they also alter the autonomic nervous system causing dysautonomia, this being important in the eye since it can raise IOP augmenting the prevalence of glaucoma in patients suffering from these two pathologies which are significantly higher than in the normal population (Bayer et al., 2002). Many patients with Parkinson's disease have a significant loss of their visual field which is typical of the development of glaucoma (Yenice et al., 2008).

Since the presence of diadenosine tetraphosphate has been demonstrated in the aqueous humour both in humans and animal models (Castany et al., 2011; Pintor et al., 2003), the possibility of this dinucleotide acting in the same way as in the CNS is a matter of interest. In this sense, it has been demonstrated in New Zealand white rabbits that the chemical destruction by means of 6-OHdopamine or reserpine, clearly eliminates sympathetic terminals altering the control of IOP among other processes. In this sense, subconjunctival injections of 6-OHDA cause sympatholysis with a sharp fall in IOP. Also a clear miosis has been observed as a consequence of the chemical denervation together with a loss of ocular sympathetic reflexes and a sharp reduction in the labelling of intraocular sympathetic neurons (Hoyle and Pintor, 2010).

On a preliminary study on the possible effect of diadenosine tetraphosphate protecting the nervous system, the application of $100 \mu \mathrm{M} \mathrm{Ap} 4$ A three days before the treatment with 6-OH dopamine or reserpine and 2 more days after the chemical denervation, preserved the sympathetic terminals present in the ciliary body from chemical denervation and therefore rabbits IOP did not fall as happens in the absence of the dinucleotide (Hoyle and Pintor, 2010). This effect is quite unusual, since the nucleotide ATP and the nucleoside adenosine were totally unable to mimic $\mathrm{Ap}_{4} \mathrm{~A}$ protective effect. Although adenosine acts via its own receptors, ATP and $\mathrm{Ap}_{4} \mathrm{~A}$ should use common $\mathrm{P} 2$ receptors (Pintor and MirasPortugal, 1995b). P2Y 2 receptors have been described in the ciliary body in New Zealand white rabbits (Martin-Gil et al., 2012). Nevertheless, and according to its pharmacology, both ATP and $\mathrm{Ap}_{4} \mathrm{~A}$ should activate this receptor the final effect being the same, which is not the case. It could be the case that a selective receptor for diadenosine polyphosphates and not activated by ATP could be the one producing this protective effect (Pintor and Miras-Portugal, 1995a, 2000). To date this is the only evidence for a selective dinucleotide receptor in the eye and more research is needed to confirm its real existence.

The way the dinucleotide $\mathrm{Ap}_{4} \mathrm{~A}$ is protecting the ciliary body against 6-OH dopamine has not been clarified to date. One possibility is that the $\mathrm{P} 2$ receptor activated by $\mathrm{Ap}_{4} \mathrm{~A}$ may induce the down-regulation (internalization) of the monomine transporter. This has been described for other transporters such as the dopamine transporter in the CNS (Xie and Miller, 2009). The involvement of P2Y receptors inhibiting transporters has already been described and moreover, this process has been shown to occur via protein kinase C-dependent mechanism (Sen et al., 1993). An alternative possibility is that $\mathrm{Ap}_{4} \mathrm{~A}$ stimulates a receptor connected to protection by limiting the negative effect of excessive reactive oxygen species. It could be the case that $\mathrm{Ap}_{4} \mathrm{~A}$ may have an indirect effect protecting neurons against free radical damage. Melatonin has been shown to protect against 6-OHDA (Dabbeni-Sala et al., 2001 ), and it is an intriguing possibility that $\mathrm{Ap}_{4} \mathrm{~A}$ can stimulate the release of melatonin from intraocular epithelium where it is synthesised (Zmijewski et al., 2009).

\subsection{Dinucleoside polyphosphates in the posterior pole}

\subsubsection{Dinucleotide effect on retinal detachment}

One of the eye parts in which the research is weaker concerning dinucleoside polyphosphates is the retina. The presence of P2 receptors that might be stimulated by dinucleotides is broad in retinal cells, nevertheless, apart from the dinucleotide effect on retinal detachments, it is only possible to establish speculations about the actions of these compounds by means of such receptors.

Some therapeutic actions involve dinucleoside polyphosphates in relevant pathological states of the retina such as retinal detachment. Receptors for nucleotides in the retinal pigmented epithelium were described in the late 90's (Peterson et al., 1997; Sullivan et al., 1997), mostly $\mathrm{P}_{2} \mathrm{Y}_{2}$ suitable for dinucleotide activation (Guzman-Aranguez et al., 2011; Guzman-Aranguez and Pintor, 2012). This fact made some researchers develop studies on animal models which were submitted to retinal detachment. In these models it was possible to demonstrate that some dinucleoside polyphosphates such as deoxycytidine tetraphospho uridine, also known as INS37217, or denufosol, was able to re-absorb the bleb between RPE and the neural retina in a very efficient way (Yerxa et al., 2002b). This dinucleotide (INS37217), which is a $\mathrm{P}_{2} \mathrm{Y}_{2}$ agonist, significantly enhanced subretinal fluid reabsorption when compared with vehicle controls (Maminishkis et al., 2002; Meyer et al., 2002; Nour et al., 2003). One positive aspect is that INS37217 had no adverse effects on electroretinograms. In this sense, both scotopic and photopic ERG amplitudes and latency parameters remained stable when INS37217 was applied, this being a beneficial aspect to take into account (Meyer et al., 2002). Other authors, on the contrary, indicate that subretinal injections of saline containing INS37217 significantly increased rod and cone ERG of normal and rds $( \pm)$ mice at 1 and 10 days post-injections, when compared with injection of saline alone (Nour et al., 2003). These experiments indicate that the dinucleotide INS37217 enhances ERG recovery probably by reducing retinal folding permitting reattachment.

It is important to note that the experiments performed with this dinucleotide demonstrated an increase in fluid absorption not only in animal models but also in freshly isolated bovine and fetal human RPE monolayers (Maminishkis et al., 2002), and therefore the molecules would be a good candidate for the treatment of retinal detachments. Nevertheless, it is not all good news. There are two main handicaps in these studies; first, denufosol in some cases, to develop its action, needs to be used at high concentrations (around $1 \mathrm{mM}$ ) (Meyer et al., 2002), which may produce the re-absorption process but presumably also the activation of many other $\mathrm{P} 2$ receptors due to the high concentrations of the dinucleotide. Second, in order to act it is necessary to be applied by means of intravitreal injections (Maminishkis et al., 2002; Meyer et al., 2002; Nour et al., 2003).

\subsubsection{Presence in other posterior structures}

As discussed above, diadenosine polyphosphates and other nucleotides could activate metabotropic and ionotropic receptors described in mammalian retina (Cowlen et al., 2003; Franke et al., 2005; Fries et al., 2004; Greenwood et al., 1997; Kaneda et al., 2008; Notomi et al., 2011; Peterson et al., 1997; Pintor et al., 2004b; Puthussery and Fletcher, 2004, 2007; Shigematsu et al., 2007; Ward et al., 2008; Wheeler-Schilling et al., 2000, 2001). Numerous studies indicate a wide distribution of purinergic receptors throughout the different layers of retina. It can be suggested 
the possible effects of dinucleotides on P2 receptors and their potential physiological roles.

The activation of purinergic receptors through nucleotides and dinucleotides, such as diadenosine polyphosphates, may be implicated in embryo development and retinal precursor cell proliferation due to the implication of $\mathrm{P} 2$ receptors described in early neural retina (Sugioka et al., 1999). Transcriptional regulation changes of these receptors during the development clearly indicate the relevant endogenous nucleotides participation.

Although both P2X and P2Y receptors have been observed in several neuronal populations including photoreceptors, amacrine and ganglion cells, recent studies suggest the implication of P2X receptors in the modulation of visual neurotransmission activity (Kaneda et al., 2008; Puthussery and Fletcher, 2004, 2007; Puthussery et al., 2006; Vessey and Fletcher, 2012) and the presumable involvement of diadenosine polyphosphates. Moreover, it could be contributing to the shedding of photoreceptor outer segments via $\mathrm{P} 2 \mathrm{Y}$ receptors.

Furthermore, nucleotides serve as vasoactive signals in the pericyte-containing microvasculature of the retina. Different studies suggest nucleotides-induced increase in calcium levels and cellular contraction (Kawamura et al., 2003; Sugiyama et al., 2006). In this sense, dinucleotides polyphosphates may contribute to regulate capillary function in retina. Moreover, P2X7 receptor activation triggered pericyte apoptosis that may be improved by

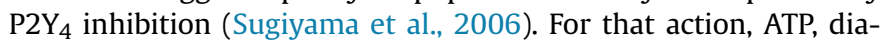
denosine polyphosphates and other nucleotides balance have particular relevance in the environmental extracellular modulation and the concomitant activation of $\mathrm{P} 2$ receptors. Apart from pericytes it is also important to take into consideration the contribution of choroid in the retinal circulation. In this sense, it is important to consider the role of nucleotides and dinucleotides due to their relevant participation in vasoactive signals in the retinal vasculature including choriocapillaris and choroidal vasculature. Several authors have observed ATP action modifying ionic currents leading contractions of pericytes as previously commented (Kawamura et al., 2003) and apoptosis processes via P2X7 receptor activation. Moreover the dinucleotide concentration in blood should also modify endothelial cells by means of $\mathrm{P}_{2} \mathrm{Y}_{2}$ receptors (Flores et al., 1999) facilitating vasodilation and therefore changing the retinal physiology.

Some of these functional implications may possibly be mediated by dinucleoside polyphosphates co-stored with ATP and classical neurotransmitters. In fact, the presence of ATP and $\mathrm{Ap}_{4} \mathrm{~A}$ levels observed in stimulated retinas indicate the importance of these molecules in neurotransmission process (Dr. Perez de Lara, personal communication).

Finally, the presence of nucleotides in retinal glial cells could be responsible for the maintenance of homeostasis regulation for suitable functioning of the neural retina, among others. The molecular cloning and functional characterization of different families of ectoenzymes capable of hydrolyzing ATP, diadenosine polyphosphates and other nucleotides point to the relevance of this complex balance maintenance.

Extracellular concentration of dinucleotides or their metabolites at retinal level are regulated by ecto-nucleotidases, nucleoside transporters and enzymes of adenosine metabolism. Neural retina, but also retinal pigment epithelium, expresses ecto-enzymes including NPP1 (described in Müller cells, the major glial component of the retina), NTPDase 2 (also expressed in Müller cells) and eN/5NTE (located on photoreceptors, Müller cells and retinal pigment epithelium) (Iandiev et al., 2007; Reigada et al., 2006; Takizawa, 1998; Wurm et al., 2010).

Again, retinal structures possess several purinergic receptors and thus, the response of their cells depends on dinucleotides and also on their metabolites, mainly ATP and adenosine (Crooke et al., 2008). Furthermore, adenosine effects in retina may be regulated by equilibrative (ENT1 and ENT2) and concentrative nucleoside transporters (CNT2 and CNT3) as well as adenosine deaminase 2 (ADA2) (Akanuma et al., 2013; dos Santos-Rodrigues et al., 2011; Elsherbiny et al., 2013; Nagase et al., 2006). In fact, patients with diabetes express a high level of ADA2, which impaired the antiinflammatory activity of adenosine at retina level (Elsherbiny et al., 2013).

Other relevant aspect that needs to be taken into consideration is the possible role of dinucleoside polyphosphates ameliorating retinal neuropathy. On the one hand, it has been described that the activation of some P2 receptors such as $\mathrm{P}_{2} \mathrm{Y}_{2}$ (Nour et al., 2003; Maminishkis et al., 2002) and P2Y 13 (Perez-Sen et al., 2015) may be involved in neuroprotection processes mediated by MAPK pathway in the retina. Moreover, the exacerbated activity of ectoenzymes (NPPs) in pathological conditions may also contribute to this process, but more work is necessary to confirm the implication of ectonucleotidases on retinal impairment.

\section{Conclusions and future directions}

The participation of dinucleoside polyphosphates in ocular physiology opens the possibility of using these compounds for the treatment of relevant eye pathologies. Beginning with the ocular surface to the retina, the application of these dinucleotides may help to improve several processes, which may be altered in the pathology.

Dry eye is treated in some countries such as Japan and South Korea by means of the dinucleotides $\mathrm{Up}_{4} \mathrm{U}$. This nucleotide can clearly increase tear secretion, both the aqueous and the mucin components. This is the only dinucleoside polyphosphate that is commercially available as a pharmaceutical compound. None of the others have moved to a clinical study as a previous step to commercialization. Nonetheless, many of the actions, mostly diadenosine polyphosphates do present very promising aspects from a therapeutic point of view as has been commented.

The advance in research needs some changes in order to be more successful in the search for dinucleotides as therapeutic agents. On the one hand, most of the compounds tested in their ability to counteract some of the pathological situations already described, have the characteristics of being fully degradable by ectonucleotidases (NPPs) therefore limiting their real effects (Asensio et al., 2007). In this sense it would be of interest to develop some compounds resistant to the hydrolysis. The best way to protect these compounds from cleavage consists of substituting the ester bonds between the phosphates by methylene or amino groups. This has been done by some researchers (Biriukov et al., 1987) although it has not been tested if they improve the efficacy of the dinucleotides already tested in the eye (Chan et al., 1997). This is an area of interest that deserves work because it may indicate that lower concentrations can produce the same or even better effects. On the other hand, it is very probable that by introducing such changes it may be possible to synthesize dinucleoside polyphosphates to become more selective to some receptors. Selectivity would permit us to reach specific targets without affecting other processes. It is important to be aware that, for example, a dinucleotide such as $\mathrm{Ap}_{4} \mathrm{~A}$ can act on several $\mathrm{P} 2$ receptors (Pintor et al., 1996; Pintor and Miras-Portugal, 1995b, 2000), and therefore it would be able to stimulate all of them while it could be the case that only a particular subtype is needed to be activated. In this sense, hydrolysis resistant and selective dinucleotides are necessary to produce better, more selective and long-term effects.

Another important aspect that deserves attention is the delivery of the dinucleotides to internal parts of the eye. It is clear that 
actions on the ocular surface are obtained by topical applications of the given dinucleotides. Nonetheless, it is important to note that intraocular actions implies the delivery through the cornea, and this may reduce the availability of the dinucleotides in the aqueous humour and in the inner structures. The use of carriers such as liposomes is a possibility, although to our knowledge, no one has tested dinucleotides with vehicles like those. Interestingly, it has been indicated that some dinucleotides such as $\mathrm{Ap}_{4} \mathrm{~A}$, when applied on the ocular surface can temporarily open corneal epithelial tightjunctions (Loma et al., 2015b) facilitating the entry of compounds within the eye (Loma et al., 2015a). This means that those actions carried out by dinucleoside polyphosphates in the inner eye may be enhanced if the application of the dinucleotide, $A_{4} A$, is applied two hours previously. It is necessary to investigate this since, if the entry of the dinucleotide is improved it is possible that it may reach very deep areas of the eye.

In conclusion, dinucleoside polyphosphates are involved in a multitude of physiological processes which are relevant for the correct functioning of the eye. There are many promising perspectives using some of these compounds from a therapeutic point of view, however it is clear that new synthetic analogues of these dinucleotides are necessary to fully develop a battery of pharmaceutical compounds suitable for ocular therapy.

\section{Disclosure}

All authors have no financial interest in the subject matter or materials discussed in this manuscript. The authors alone are responsible for the content and writing of the paper.

\section{Acknowledgments}

This work was supported by grants from Ministerio de Ciencia e Innovación (SAF2010-16024 and SAF2013-44416-R) and RETICS (RD12/0034/0003).

\section{References}

Abbracchio, M.P., Ceruti, S., 2006. Roles of P2 receptors in glial cells: focus on astrocytes. Purinergic Signal 2, 595-604.

Akanuma, S., Soutome, T., Hisada, E., Tachikawa, M., Kubo, Y., Hosoya, K., 2013. Na+independent nucleoside transporters regulate adenosine and hypoxanthine levels in Muller cells and the inner blood-retinal barrier. Invest.Investig. Ophthalmol. Vis. Sci. 54, 1469-1477.

Alfonso, J.F., Lisa, C., Fernandez-Vega Cueto, L., Belda-Salmeron, L., Madrid-Costa, D. Montes-Mico, R., 2013. Clinical outcomes after implantation of a posterior chamber collagen copolymer phakic intraocular lens with a central hole for myopic correction. J. Cataract. Refract Surg. 39, 915-921.

Ali, M., Kamiya, K., Shimizu, K., Igarashi, A., Ishii, R., 2014. Clinical evaluation of corneal biomechanical parameters after posterior chamber phakic intraocular lens implantation. Cornea 33, 470-474.

Alkozi, H.A., Pintor, J., 2015. TRPV4 activation triggers the release of melatonin from human non-pigmented ciliary epithelial cells. Exp. Eye Res. 136, 34-37.

Andersson, M., 1989. Diadenosine tetraphosphate (Ap4A): its presence and functions in biological systems. Int. J. Biochem. 21, 707-714.

Arita, R., Suehiro, J., Haraguchi, T., Maeda, S., Maeda, K., Tokoro, H., Amano, S., 2013. Topical diquafosol for patients with obstructive meibomian gland dysfunction. Br. J. Ophthalmol. 97, 725-729.

Arnold, R.R., Cole, M.F., McGhee, J.R., 1977. A bactericidal effect for human lactoferrin. Science 197, 263-265.

Asensio, A.C., Rodriguez-Ferrer, C.R., Castaneyra-Perdomo, A., Oaknin, S., Rotllan, P., 2007. Biochemical analysis of ecto-nucleotide pyrophosphatase phosphodiesterase activity in brain membranes indicates involvement of NPP1 isoenzyme in extracellular hydrolysis of diadenosine polyphosphates in central nervous system. Neurochem. Int. 50, 581-590.

Baker, O.J., Camden, J.M., Rome, D.E., Seye, C.I., Weisman, G.A., 2008. P2Y2 nucleotide receptor activation up-regulates vascular cell adhesion molecule-1 [corrected] expression and enhances lymphocyte adherence to a human submandibular gland cell line. Mol. Immunol. 45, 65-75.

Bambara, R.A., Crute, J.J., Wahl, A.F., 1985. Is Ap4A an activator of eukaryotic DNA replication? Cancer Invest.Investig. 3, 473-479.

Ban, Y., Cooper, L.J., Fullwood, N.J., Nakamura, T., Tsuzuki, M., Koizumi, N., Dota, A., Mochida, C., Kinoshita, S., 2003. Comparison of ultrastructure, tight junction- related protein expression and barrier function of human corneal epithelial cells cultivated on amniotic membrane with and without air-lifting. Exp. Eye Res. 76, 735-743.

Bayer, A.U., Keller, O.N., Ferrari, F., Maag, K.P., 2002. Association of glaucoma with neurodegenerative diseases with apoptotic cell death: Alzheimer's disease and Parkinson's disease. Am. J. Ophthalmol. 133, 135-137.

Biriukov, A.P., Zakharova, O.D., Lavrik, O.I., 1987. [Effect of diadenosine oligophosphates (Ap4A and Ap3A) and their phosphonate analogs on catalytic properties of phenylalanyl-tRNA synthetase from E. coli]. Bioorg Khim 13, 1164-1169.

Bonan, C.D., 2012. Ectonucleotidases and nucleotide/nucleoside transporters as pharmacological targets for neurological disorders. CNS Neurol. Disord. Drug Targets 11, 739-750.

Boucher, I., Rich, C., Lee, A., Marcincin, M., Trinkaus-Randall, V., 2010. The P2Y2 receptor mediates the epithelial injury response and cell migration. Am. J. Physiol. Cell Physiol. 299, C411-C421.

Bowman, K.A., Green, K., 1981. Corneal epithelial healing rates after topical nucleotides. Curr. Eye Res. 1, 619-622.

Braun, J.S., 2010. Ecto-5'-nucleotidase-positive cells in the choroid and ciliary body of the rat eye. Anat. Rec. Hob. 293, 379-382.

Bremond-Gignac, D., Gicquel, J.J., Chiambaretta, F., 2014. Pharmacokinetic evaluation of diquafosol tetrasodium for the treatment of Sjogren's syndrome. Expert Opin. Drug Metab. Toxicol. 10, 905-913.

Brennan, N.A., Efron, N., Holden, B.A., Fatt, I., 1987. A review of the theoretical concepts, measurement systems and application of contact lens oxygen permeability. Ophthalmic \& Physiol. Opt. J. Br. Coll. Ophthalmic Opt. 7, $485-490$.

Burman, L.G., Lundblad, G., Camner, P., Fange, R., Lundborg, M., Soder, P., 1991. Lysozyme-an enzyme of both historical and current interest as a therapeutical agent. Lakartidningen 88, 3665-3668.

Bush, C.A., Tinoco Jr., I., 1967. Calculation of the optical rotatory dispersion of dinucleoside phosphates. J. Mol. Biol. 23, 601-604.

Byun, Y.S., Yoo, Y.S., Kwon, J.Y., Joo, J.S., Lim, S.A., Whang, W.J., Mok, J.W., Choi, J.S., Joo, C.K., 2016. Diquafosol promotes corneal epithelial healing via intracellular calcium-mediated ERK activation. Exp. Eye Res. 143, 89-97.

Cabrera, M.J. Velasco, Sanchez, J. Garcia, Rodriguez, F.J. Bermudez, 1997. Lactoferrin in tears in contact lens wearers. CLAO J. Off. Publ. Contact Lens Assoc. Ophthalmol. Inc 23, 127-129.

Caffery, B., Joyce, E., Boone, A., Slomovic, A., Simpson, T., Jones, L., Senchyna, M., 2008. Tear lipocalin and lysozyme in Sjogren and non-Sjogren dry eye. Optom. Vis. Sci. 85, 661-667.

Carracedo, G., Peral, A., Pintor, J., 2010. Diadenosine polyphosphates in tears of Sjogren syndrome patients. Invest.Investig. Ophthalmol. Vis. Sci. 51, 5452-5459.

Carracedo, G., Gonzalez-Meijome, J.M., Pintor, J., 2012. Changes in diadenosine polyphosphates during alignment-fit and orthokeratology rigid gas permeable lens wear. Invest.Investig. Ophthalmol. Vis. Sci. 53, 4426-4432.

Carracedo, G., Guzman-Aranguez, A., Loma, P., Pintor, J., 2013. Diadenosine polyphosphates release by human corneal epithelium. Exp. Eye Res. 113, 156-161.

Carracedo, G., Cacho, I., Sanchez-Naves, J., Pintor, J., 2014. Diadenosine polyphosphates after laser in situ keratomileusis and photorefractive keratectomy refractive techniques. Acta Ophthalmol. 92, e5-e11.

Carracedo, G., Martin-Gil, A., Peixoto-de-Matos, S.C., Abejon-Gil, P., Macedo-deAraujo, R., Gonzalez-Meijome, J.M., 2015a. Symptoms and signs in rigid gas permeable lens wearers during adaptation period. Eye Contact Lens 42 (2), $108-114$.

Carracedo, G., Recchioni, A., Alejandre-Alba, N., Martin-Gil, A., Crooke, A., Morote, I.J., Pintor, J., 2015b. Signs and symptoms of dry eye in Keratoconus patients: a pilot study. Curr. Eye Res. 40, 1088-1094.

Carracedo, G., Blanco, M.S., Martin-Gil, A., Zicheng, W., Alvarez, J.C., Pintor, J., 2016. Short-term effect of Scleral lens on the dry eye biomarkers in Keratoconus. Optom. Vis. Sci. 93, 150-157.

Castany, M., Jordi, I., Catala, J., Gual, A., Morales, M., Gasull, X., Pintor, J., 2011. Glaucoma patients present increased levels of diadenosine tetraphosphate, $\mathrm{Ap}(4) \mathrm{A}$, in the aqueous humour. Exp. Eye Res. 92, 221-226.

Chan, S.I., Nelson, J.H., 1969. Proton magnetic resonance studies of ribose dinucleoside monophoshates in aqueous solution. I. The nature of the base-stacking interaction in adenylyl 3'-5')adenosine. J. Am. Chem. Soc. 91, 168-183.

Chan, S.W., Gallo, S.J., Kim, B.K., Guo, M.J., Blackburn, G.M., Zamecnik, P.C., 1997. P1,P4-dithio-P2,P3-monochloromethylene diadenosine 5',5"-P1,P4tetraphosphate: a novel antiplatelet agent. Proc. Natl. Acad. Sci. U. S. A. 94, 4034-4039.

Cheng, P.Y., 1968. Characteristic optical rotatory dispersion spectra of thirteen dinucleoside phosphates with mercurials. Biochem. Biophys. Res. Commun. 33, $746-751$.

Chia, E.M., Mitchell, P., Rochtchina, E., Lee, A.J., Maroun, R., Wang, J.J., 2003. Prevalence and associations of dry eye syndrome in an older population: the Blue Mountains eye study. Clin. Exp. Ophthalmol. 31, 229-232.

Cockayne, D.A., Hamilton, S.G., Zhu, Q.M., Dunn, P.M., Zhong, Y., Novakovic, S., Malmberg, A.B., Cain, G., Berson, A., Kassotakis, L., Hedley, L., Lachnit, W.G., Burnstock, G., McMahon, S.B., Ford, A.P., 2000. Urinary bladder hyporeflexia and reduced pain-related behaviour in P2X3-deficient mice. Nature 407, 1011-1015. Coddou, C., Yan, Z., Obsil, T., Huidobro-Toro, J.P., Stojilkovic, S.S., 2011. Activation and regulation of purinergic P2X receptor channels. Pharmacol. Rev. 63, 641-683.

Conneely, O.M., 2001. Antiinflammatory activities of lactoferrin. J. Am. Coll. Nutr. 20, 389S-395S discussion 396S-397S. 
Cornish, R., Sulaiman, S., 1996. Do thinner rigid gas permeable contact lenses provide superior initial comfort? optometry and vision science. Off. Publ. Am. Acad. Optom. 73, 139-143.

Corrales, R.M., Narayanan, S., Fernandez, I., Mayo, A., Galarreta, D.J., FuentesPaez, G., Chaves, F.J., Herreras, J.M., Calonge, M., 2011. Ocular mucin gene expression levels as biomarkers for the diagnosis of dry eye syndrome. Invest.Investig. Ophthalmol. Vis. Sci. 52, 8363-8369.

Cowlen, M.S., Zhang, V.Z., Warnock, L., Moyer, C.F., Peterson, W.M., Yerxa, B.R., 2003. Localization of ocular P2Y2 receptor gene expression by in situ hybridization. Exp. Eye Res. 77, 77-84.

Crooke, A., Guzman-Aranguez, A., Peral, A., Abdurrahman, M.K., Pintor, J., 2008. Nucleotides in ocular secretions: their role in ocular physiology. Pharmacol. Ther. 119, 55-73.

Crooke, A., Mediero, A., Guzman-Aranguez, A., Pintor, J., 2009. Silencing of P2Y2 receptor delays Ap4A-corneal re-epithelialization process. Mol. Vis. 15, 1169-1178.

Crosson, C.E., Yates, P.W., Bhat, A.N., Mukhin, Y.V., Husain, S., 2004. Evidence for multiple P2Y receptors in trabecular meshwork cells. J. Pharmacol. Exp. Ther. 309, 484-489.

Dabbeni-Sala, F., Di Santo, S., Franceschini, D., Skaper, S.D., Giusti, P., 2001. Melatonin protects against 6-OHDA-induced neurotoxicity in rats: a role for mitochondrial complex I activity. FASEB J. 15, 164-170.

Davidson, A.E., Hayes, S., Hardcastle, A.J., Tuft, S.J., 2014. The pathogenesis of keratoconus. Eye (Lond.) 28, 189-195.

Davis, R.C., Tinoco Jr., I., 1968. Temperature-dependent properties of dinucleoside phosphates. Biopolymers 6, 223-242.

Dominguez-Godinez, C.O., Martin-Gil, A., Carracedo, G., Guzman-Aranguez, A. Gonzalez-Meijome, J., Pintor, J., 2013. In Vitro and in Vivo delivery of the secretagogue diadenosine tetraphosphate from conventional and silicone hydrogel soft contact lenses. J Optom. 06, 205-211.

dos Santos-Rodrigues, A., Ferreira, J.M., Paes-de-Carvalho, R., 2011. Differential adenosine uptake in mixed neuronal/glial or purified glial cultures of avian retinal cells: modulation by adenosine metabolism and the ERK cascade. Biochem. Biophys. Res. Commun. 414, 175-180.

Dutot, M., Liang, H., Pauloin, T., Brignole-Baudouin, F., Baudouin, C., Warnet, J.M., Rat, P., 2008. Effects of toxic cellular stresses and divalent cations on the human P2X7 cell death receptor. Mol. Vis. 14, 889-897.

Elbendary, A.M., Abou Samra, W., 2013. Evaluation of rigid gas permeable lens fitting in keratoconic patients with optical coherence tomography. Graefes Arch. Clin. Exp. Ophthalmol. 251, 1565-1570.

Elsherbiny, N.M., Naime, M., Ahmad, S., Elsherbini, A.M., Mohammad, S., Fulzele, S. El-Remessy, A.B., Al-Gayyar, M.M., Eissa, L.A., El-Shishtawy, M.M., Han, G., White, R., Haroldo, T.F., Liou, G.I., 2013. Potential roles of adenosine deaminase2 in diabetic retinopathy. Biochem. Biophys. Res. Commun. 436, 355-361.

Farahbakhsh, N.A., 2003. Ectonucleotidases of the rabbit ciliary body nonpigmented epithelium. Invest.Investig. Ophthalmol. Vis. Sci. 44, 3952-3960.

Farris, R.L., 1986. Tear analysis in contact lens wearers. CLAO J. 12, 106-111.

Ferguson, D.R., Kennedy, I., Burton, T.J., 1997. ATP is released from rabbit urinary bladder epithelial cells by hydrostatic pressure changes-a possible sensory mechanism? J. Physiol. 505 (Pt 2), 503-511.

Finamore, F.J., Warner, A.H., 1963. The occurrence of P1, P4-diguanosine 5'-tetraphosphate in brine shrimp eggs. J. Biol. Chem. 238, 344-348.

Fink, B.A., Hill, R.M., Carney, L.G., 1992. Influence of rigid contact lens base curve radius on tear pump efficiency. Optom. Vis. Sci. Off. Publ. Am. Acad. Optom. 69, 60-65.

Flanagan, J.L., Willcox, M.D., 2009. Role of lactoferrin in the tear film. Biochimie 91, $35-43$.

Flodgaard, H., Klenow, H., 1982. Abundant amounts of diadenosine 5',5'"'-P1,P4tetraphosphate are present and releasable, but metabolically inactive, in human platelets. Biochem. J. 208, 737-742.

Flores, N.A., Stavrou, B.M., Sheridan, D.J., 1999. The effects of diadenosine polyphosphates on the cardiovascular system. Cardiovasc Res. 42, 15-26.

Fonseca, B., Martinez-Aguila, A., Diaz-Hernandez, M., Pintor, J., 2015. Diadenosine tetraphosphate contributes to carbachol-induced tear secretion. Purinergic Signal 11, 87-93.

Franco, R., Casado, V., Ciruela, F., Saura, C., Mallol, J., Canela, E.I., Lluis, C., 1997. Cell surface adenosine deaminase: much more than an ectoenzyme. Prog. Neurobiol. 52, 283-294.

Franke, H., Klimke, K., Brinckmann, U., Grosche, J., Francke, M., Sperlagh, B. Reichenbach, A., Liebert, U.G., Illes, P., 2005. P2X(7) receptor-mRNA and -protein in the mouse retina; changes during retinal degeneration in BALBCrds mice. Neurochem. Int. 47, 235-242.

Fries, J.E., Wheeler-Schilling, T.H., Guenther, E., Kohler, K., 2004. Expression of P2Y1, $\mathrm{P} 2 \mathrm{Y} 2, \mathrm{P} 2 \mathrm{Y} 4$, and P2Y6 receptor subtypes in the rat retina. Invest.Investig. Ophthalmol. Vis. Sci. 45, 3410-3417.

Frohlich, R., Boehm, S., Illes, P., 1996. Pharmacological characterization of P2 purinoceptor types in rat locus coeruleus neurons. Eur. J. Pharmacol. 315, 255-261.

Fujihara, T., Murakami, T., Fujita, H., Nakamura, M., Nakata, K., 2001. Improvement of corneal barrier function by the P2Y(2) agonist INS365 in a rat dry eye model. Invest.Investig. Ophthalmol. Vis. Sci. 42, 96-100.

Fujihara, T., Murakami, T., Nagano, T., Nakamura, M., Nakata, K., 2002. INS365 suppresses loss of corneal epithelial integrity by secretion of mucin-like glycoprotein in a rabbit short-term dry eye model. J. Ocul. Pharmacol. Ther. $18,363-370$.

Galvis, V., Tello, A., Barrera, R., Nino, C.A., 2015. Inflammation in Keratoconus.
Cornea 34, e22-23.

Gendaszewska-Darmach, E., Kucharska, M., 2011. Nucleotide receptors as targets in the pharmacological enhancement of dermal wound healing. Purinergic Signal 7, 193-206.

Gipson, I.K., 2007. The ocular surface: the challenge to enable and protect vision: the Friedenwald lecture. Invest.Investig. Ophthalmol. Vis. Sci. 48 (4390) 4391-4398.

Giraldez, L., Diaz-Hernandez, M., Gomez-Villafuertes, R., Pintor, J., Castro, E., MirasPortugal, M.T., 2001. Adenosine triphosphate and diadenosine pentaphosphate induce $[\mathrm{Ca}(2+)](\mathrm{i})$ increase in rat basal ganglia aminergic terminals. J. Neurosci. Res. 64, 174-182.

Glaser, T., Walton, D.S., Maas, R.L., 1992. Genomic structure, evolutionary conservation and aniridia mutations in the human PAX6 gene. Nat. Genet. 2, 232-239.

Glaser, T., Ton, C.C., Mueller, R., Petzl-Erler, M.L., Oliver, C., Nevin, N.C. Housman, D.E., Maas, R.L., 1994. Absence of PAX6 gene mutations in Gillespie syndrome (partial aniridia, cerebellar ataxia, and mental retardation). Genomics 19, 145-148.

Glaubiger, D., Lloyd, D.A., Tinoco Jr., I., 1968. Temperature-dependent optical properties of a torsional oscillator model for dinucleoside phosphates. Biopolymers $6,409-414$.

Gobbels, M., Breitbach, R., Spitznas, M., 1990. Barrier function of the corneal epithelium of contact lens patients. Fortschr. Ophthalmol. Z. Dtsch. Ophthalmol. Ges. 87, 646-648.

Goding, J.W., Terkeltaub, R., Maurice, M., Deterre, P., Sali, A., Belli, S.I., 1998. Ectophosphodiesterase/pyrophosphatase of lymphocytes and non-lymphoid cells: structure and function of the PC-1 family. Immunol. Rev. 161, 11-26.

Goel, M., Picciani, R.G., Lee, R.K., Bhattacharya, S.K., 2010. Aqueous humor dynamics: a review. Open Ophthalmol. J. 4, 52-59.

Gomes, P., Srinivas, S.P., Vereecke, J., Himpens, B., 2005. ATP-dependent paracrine intercellular communication in cultured bovine corneal endothelial cells. Invest.Investig. Ophthalmol. Vis. Sci. 46, 104-113.

Greenwood, D., Yao, W.P., Housley, G.D., 1997. Expression of the P2X2 receptor subunit of the ATP-gated ion channel in the retina. Neuroreport 8, 1083-1088.

Groschel-Stewart, U., Bardini, M., Robson, T., Burnstock, G., 1999. Localisation of P2X5 and P2X7 receptors by immunohistochemistry in rat stratified squamous epithelia. Cell Tissue Res. 296, 599-605.

Grummt, F., 1978. Diadenosine 5' 5"'-P1,P4-tetraphosphate triggers initiation of in vitro DNA replication in baby hamster kidney cells. Proc. Natl. Acad. Sci. U. S. A. $75,371-375$.

Grummt, F., 1979. Diadenosine tetraphosphate triggers in vitro DNA replication. Cold Spring Harb. Symp. Quant. Biol. 43 (Pt 1), 649-653.

Grummt, F., 1983. Diadenosine tetraphosphate (Ap4A): a putative chemica messenger of cell proliferation control and inducer of DNA replication: review paper. Plant Mol. Biol. 2, 41-44.

Grummt, F., Waltl, G., Jantzen, H.M., Hamprecht, K., Huebscher, U., Kuenzle, C.C., 1979. Diadenosine 5',5'-P1,P4-tetraphosphate, a ligand of the 57-kilodalton subunit of DNA polymerase alpha. Proc. Natl. Acad. Sci. U. S. A. 76, 6081-6085.

Gualix, J., Gomez-Villafuertes, R., Diaz-Hernandez, M., Miras-Portugal, M.T., 2003. Presence of functional ATP and dinucleotide receptors in glutamatergic synaptic terminals from rat midbrain. J. Neurochem. 87, 160-171.

Guillon, M., Maissa, C., 2010. Tear film evaporation-effect of age and gender. Cont. Lens Anterior Eye 33, 171-175.

Guranowski, A., 2000. Specific and nonspecific enzymes involved in the catabolism of mononucleoside and dinucleoside polyphosphates. Pharmacol. Ther. 87, $117-139$.

Guranowski, A., Starzynska, E., Gunther Sillero, M.A., Sillero, A., 1995. Conversion of adenosine $\left(5^{\prime}\right)$ oligophospho( $\left.5^{\prime}\right)$ adenosines into inosine $\left(5^{\prime}\right)$ oligophospho( $5^{\prime}$ inosines by non-specific adenylate deaminase from the snail Helix pomatia. Biochim. Biophys. Acta 1243, 78-84.

Guzman-Aranguez, A., Pintor, J., 2012. Focus on molecules: purinergic P2Y(2) receptor. Exp. Eye Res. 105, 83-84.

Guzman-Aranguez, A., Crooke, A., Peral, A., Hoyle, C.H., Pintor, J., 2007. Dinucleoside polyphosphates in the eye: from physiology to therapeutics. Prog. Retin Eye Res. 26, 674-687.

Guzman-Aranguez, A., Loma, P., Pintor, J., 2011. Focus on molecules: diadenosine tetraphosphate. Exp. Eye Res. 92, 96-97.

Guzman-Aranguez, A., Diez, L.M., Martin-Gil, A., Gualix, J., Miras-Portugal, M.T. Pintor, J., 2012. Effect of diinosine polyphosphates on intraocular pressure in normotensive rabbits. Exp. Eye Res. 101, 49-55.

Guzman-Aranguez, A., Santano, C., Martin-Gil, A., Fonseca, B., Pintor, J., 2013. Nucleotides in the eye: focus on functional aspects and therapeutic perspectives J. Pharmacol. Exp. Ther. 345, 331-341.

Guzman-Aranguez, A., Gasull, X., Diebold, Y., Pintor, J., 2014. Purinergic receptors in ocular inflammation. Mediat. Inflamm. 2014, 320906.

Guzman-Aranguez, A., Fonseca, B., Carracedo, G., Martin-Gil, A., Martinez-Aguila, A., Pintor, J., 2015. Dry eye treatment based on contact lens drug delivery: a review. Eye Contact Lens [Epub ahead of print].

Habermacher, C., Dunning, K., Chataigneau, T., Grutter, T., 2015. Molecular structure and function of P2X receptors. Neuropharmacology 104, 18-30.

Hansen, P.B., Hristovska, A., Wolff, H., Vanhoutte, P., Jensen, B.L., Bie, P., 2010. Uridine adenosine tetraphosphate affects contractility of mouse aorta and decreases blood pressure in conscious rats and mice. Acta Physiol. (Oxf) 200, 171-179.

Harvey, B.K., Chou, J., Shen, H., Hoffer, B.J., Wang, Y., 2009. Diadenosine tetraphosphate reduces toxicity caused by high-dose methamphetamine administration. Neurotoxicology 30, 436-444. 
Herrero-Vanrell, R., Peral, A., 2007. International dry eye workshop (DEWS). Update of the disease. Arch. Soc. Esp. Oftalmol. 82, 733-734.

Hodges, R.R., Vrouvlianis, J., Shatos, M.A., Dartt, D.A., 2009. Characterization of P2X7 purinergic receptors and their function in rat lacrimal gland. Invest.Investig. Ophthalmol. Vis. Sci. 50, 5681-5689.

Hodges, M.D., Kelly, J.G., Bentley, A.J., Fogarty, S., Patel II, Martin, F.L., Fullwood, N.J., 2011. Combining immunolabeling and surface-enhanced Raman spectroscopy on cell membranes. ACS Nano 5, 9535-9541.

Hoyle, C.H., Pintor, J.J., 2010. Diadenosine tetraphosphate protects sympathetic terminals from 6-hydroxydopamine-induced degeneration in the eye. Acta Physiol. (Oxf) 199, 205-210.

Hoyle, C.H.V., Hilderman, R., Pintor, J.J., Schlüter, H., King, B.F., 2001. Diadenosine polyphosphates as extracellular signal molecules. Drug Dev. Res. 52 (2001) 260-273.

Hoyle, C.H., Peral, A., Pintor, J., 2006. Melatonin potentiates tear secretion induced by diadenosine tetraphosphate in the rabbit. Eur. J. Pharmacol. 552, 159-161.

Hruska, F.E., Danyluk, S.S., 1968. Conformational changes of the ribose group in dinucleoside mono- and diphosphates. Temperature dependence. J. Am. Chem. Soc. 90, 3266-3267.

Hu, R.G., Suzuki-Kerr, H., Webb, K.F., Rhodes, J.D., Collison, D.J., Duncan, G., Donaldson, P.J., 2008. Molecular and functional mapping of regional differences in P2Y receptor expression in the rat lens. Exp. Eye Res. 87, 137-146.

Huang, H.S., Schoenwald, R.D., Lach, J.L., 1983. Corneal penetration behavior of betablocking agents III: in vitro-in vivo correlations. J. Pharm. Sci. 72, 1279-1281.

Huang, A.J., Tseng, S.C., Kenyon, K.R., 1989. Paracellular permeability of corneal and conjunctival epithelia. Invest.Investig. Ophthalmol. Vis. Sci. 30, 684-689.

Huete, F., Guzman-Aranguez, A., Ortin, J., Hoyle, C.H., Pintor, J., 2011. Effects of diadenosine tetraphosphate on FGF9-induced chloride flux changes in achondroplastic chondrocytes. Purinergic Signal 7, 243-249.

Iandiev, I., Wurm, A., Pannicke, T., Wiedemann, P., Reichenbach, A., Robson, S.C. Zimmermann, H., Bringmann, A., 2007. Ectonucleotidases in Muller glial cells of the rodent retina: involvement in inhibition of osmotic cell swelling. Purinergic Signal 3, 423-433.

Ikehara, M., Uesugi, S., Yasumoto, M., 1970. A highly stacked dinucleoside monophosphate derived from adenine 8-cyclonucleosides. J. Am. Chem. Soc. 92, 4735-4736.

Jacobson, K.A., Boeynaems, J.M., 2010. P2Y nucleotide receptors: promise of therapeutic applications. Drug Discov. Today 15, 570-578.

Jacobson, K.A., Gao, Z.G., 2006. Adenosine receptors as therapeutic targets. Nat. Rev. Drug Discov. 5, 247-264.

Jacobson, K.A., Balasubramanian, R., Deflorian, F., Gao, Z.G., 2012. G protein-coupled adenosine (P1) and P2Y receptors: ligand design and receptor interactions. Purinergic Signal 8, 419-436.

Jacobson, K.A., Paoletta, S., Katritch, V., Wu, B., Gao, Z.G., Zhao, Q., Stevens, R.C., Kiselev, E., 2015. Nucleotides acting at P2Y receptors: connecting structure and function. Mol. Pharmacol. 88, 220-230.

Jia, C., Hegg, C.C., 2012. Neuropeptide Y and extracellular signal-regulated kinase mediate injury-induced neuroregeneration in mouse olfactory epithelium. Mol. Cell Neurosci. 49, 158-170.

Jin-Hua, P., Goding, J.W., Nakamura, H., Sano, K., 1997. Molecular cloning and chromosomal localization of PD-Ibeta (PDNP3), a new member of the human phosphodiesterase I genes. Genomics 45, 412-415.

Jones, L., Brennan, N.A., Gonzalez-Meijome, J., Lally, J., Maldonado-Codina, C., Schmidt, T.A., Subbaraman, L., Young, G., Nichols, J.J., members of the T.I.W.o.C.L.D, 2013. The TFOS international workshop on contact lens discomfort: report of the contact lens materials, design, and care subcommittee. Invest.Investig. Ophthalmol. Vis. Sci. 54, 37-70.

Jumblatt, J.E., Jumblatt, M.M., 1998. Regulation of ocular mucin secretion by P2Y2 nucleotide receptors in rabbit and human conjunctiva. Exp. Eye Res. 67, 341-346.

Kamada, Y., Saino, T., Oikawa, M., Kurosaka, D., Satoh, Y., 2012. P2Y purinoceptors induce changes in intracellular calcium in acinar cells of rat lacrimal glands. Histochem Cell Biol. 137, 97-106.

Kamiya, K., Shimizu, K., Komatsu, M., 2010. Implantable Collamer Lens implantation and limbal relaxing incisions for the correction of hyperopic astigmatism after laser in situ keratomileusis. Cornea 29, 99-101.

Kamiya, K., Nakanishi, M., Ishii, R., Kobashi, H., Igarashi, A., Sato, N., Shimizu, K., 2012. Clinical evaluation of the additive effect of diquafosol tetrasodium on sodium hyaluronate monotherapy in patients with dry eye syndrome: a prospective, randomized, multicenter study. Eye (Lond.) 26, 1363-1368.

Kaneda, M., Ishii, T., Hosoya, T., 2008. Pathway-dependent modulation by P2purinoceptors in the mouse retina. Eur. J. Neurosci. 28, 128-136.

Karcioglu, Z.A., Fleming, J.C., 2008. Long-term retention rates and complications of silicone punctal plugs in dry eye. Am. J. Ophthalmol. 145, 586 author reply $586-587$.

Kawamura, H., Sugiyama, T., Wu, D.M., Kobayashi, M., Yamanishi, S., Katsumura, K. Puro, D.G., 2003. ATP: a vasoactive signal in the pericyte-containing microvasculature of the rat retina. J. Physiol. 551, 787-799.

Klepeis, V.E., Weinger, I., Kaczmarek, E., Trinkaus-Randall, V., 2004. P2Y receptors play a critical role in epithelial cell communication and migration. J. Cell Biochem. 93, 1115-1133.

Klishin, A., Lozovaya, N., Pintor, J., Miras-Portugal, M.T., Krishtal, O., 1994. Possible functional role of diadenosine polyphosphates: negative feedback for excitation in hippocampus. Neuroscience 58, 235-236.

Knight, G.E., Burnstock, G., 2001. Identification of P1 and P2 purinoceptors in the aorta of the lizard (Agama sp.). Comp. Biochem. Physiol. C Toxicol. Pharmacol. $128,413-423$.

Knop, E., Knop, N., 2007. Anatomy and immunology of the ocular surface. Chem. Immunol. Allergy 92, 36-49.

Koh, S., Ikeda, C., Takai, Y., Watanabe, H., Maeda, N., Nishida, K., 2013a. Long-term results of treatment with diquafosol ophthalmic solution for aqueous-deficient dry eye. Jpn. J. Ophthalmol. 57, 440-446.

Koh, S., Maeda, N., Ikeda, C., Takai, Y., Fujimoto, H., Oie, Y., Soma, T., Tsujikawa, M., Nishida, K., 2013b. Effect of instillation of eyedrops for dry eye on optical quality. Invest.Investig. Ophthalmol. Vis. Sci. 54, 4927-4933.

Koh, S., Maeda, N., Ikeda, C., Oie, Y., Soma, T., Tsujikawa, M., Watanabe, H., Nishida, K., 2014. Effect of diquafosol ophthalmic solution on the optical quality of the eyes in patients with aqueous-deficient dry eye. Acta Ophthalmol. 92. $671-675$.

Kojima, T., Higuchi, A., Goto, E., Matsumoto, Y., Dogru, M., Tsubota, K., 2008. Autologous serum eye drops for the treatment of dry eye diseases. Cornea 27 (Suppl. 1), S25-S30.

Kojima, T., Dogru, M., Ibrahim, O.M., Nagata, T., Higa, K., Shimizu, T., Shirasawa, T., Satake, Y., Shimazaki, S., Shimazaki, J., Tsubota, K., 2014. The effects of 3\% diquafosol sodium application on the tear functions and ocular surface of the Cu,Zn-superoxide dismutase-1 (Sod1)-knockout mice. Mol. Vis. 20, 929-938.

Kompella, U.B., Kadam, R.S., Lee, V.H., 2010. Recent advances in ophthalmic drug delivery. Ther. Deliv. 1, 435-456.

Kuizenga, A., van Haeringen, N.J., Meijer, F., Kijlstra, A., 1996. Analysis of human tear fluid components, inhibiting protein adhesion to plastic surfaces. Exp. Eye Res. 63, 319-328.

Kurpakus, M.A., Daneshvar, C., Davenport, J., Kim, A., 1999. Human corneal epithelial cell adhesion to laminins. Curr. Eye Res. 19, 106-114.

Langbein, L., Grund, C., Kuhn, C., Praetzel, S., Kartenbeck, J., Brandner, J.M., Moll, I., Franke, W.W., 2002. Tight junctions and compositionally related junctional structures in mammalian stratified epithelia and cell cultures derived therefrom. Eur. J. Cell Biol. 81, 419-435.

Lazarowski, E.R., Watt, W.C., Stutts, M.J., Boucher, R.C., Harden, T.K., 1995. Pharmacological selectivity of the cloned human P2U-purinoceptor: potent activation by diadenosine tetraphosphate. Br. J. Pharmacol. 116, 1619-1627.

Lee, C.H., Charney, E., Tinoco Jr., I., 1979. Conformations of dinucleoside phosphates in aqueous solution. Biochemistry 18, 5636-5641.

Lee, P.C., Bochner, B.R., Ames, B.N., 1983. AppppA, heat-shock stress, and cell oxidation. Proc. Natl. Acad. Sci. U. S. A. 80, 7496-7500.

Lee, A.J., Lee, J., Saw, S.M., Gazzard, G., Koh, D., Widjaja, D., Tan, D.T., 2002. Prevalence and risk factors associated with dry eye symptoms: a population based study in Indonesia. Br. J. Ophthalmol. 86, 1347-1351.

Lehrer, M.S., Sun, T.T., Lavker, R.M., 1998. Strategies of epithelial repair: modulation of stem cell and transit amplifying cell proliferation. J. Cell Sci. 111 (Pt 19), 2867-2875.

Lema, I., Duran, J.A., Ruiz, C., Diez-Feijoo, E., Acera, A., Merayo, J., 2008. Inflammatory response to contact lenses in patients with keratoconus compared with myopic subjects. Cornea 27, 758-763.

Lemp, M.A., Mathers, W.D., 1989. Corneal epithelial cell movement in humans. Eye (Lond.) 3 (Pt 4), 438-445.

Leong, Y.Y., Tong, L., 2015. Barrier function in the ocular surface: from conventional paradigms to new opportunities. Ocul. Surf. 13, 103-109.

Levoye, A., Jockers, R., Ayoub, M.A., Delagrange, P., Savaskan, E., Guillaume, J.L., 2006. Are G protein-coupled receptor heterodimers of physiological relevance?-focus on melatonin receptors. Chronobiol Int. 23, 419-426.

Li, Y., Kuang, K., Yerxa, B., Wen, Q., Rosskothen, H., Fischbarg, J., 2001. Rabbit conjunctival epithelium transports fluid, and P2Y2(2) receptor agonists stimulate $\mathrm{Cl}(-)$ and fluid secretion. Am. J. Physiol. Cell Physiol. 281, C595-C602.

Li, A., Leung, C.T., Peterson-Yantorno, K., Stamer, W.D., Civan, M.M., 2011. Cytoskeletal dependence of adenosine triphosphate release by human trabecular meshwork cells. Invest.Investig. Ophthalmol. Vis. Sci. 52, 7996-8005.

Lin, P.Y., Tsai, S.Y., Cheng, C.Y., Liu, J.H., Chou, P., Hsu, W.M., 2003. Prevalence of dry eye among an elderly Chinese population in Taiwan: the Shihpai eye study. Ophthalmology 110, 1096-1101.

Liu, C.Y., Kao, W.W., 2015. Corneal epithelial wound healing. Prog. Mol. Biol. Transl. Sci. 134, 61-71.

Loma, P., Guzman-Aranguez, A., Perez de Lara, M.J., Pintor, J., 2015a. Diadenosine tetraphosphate improves adrenergic anti-glaucomatous drug delivery and efficiency. Exp. Eye Res. 134, 141-147.

Loma, P., Guzman-Aranguez, A., Perez de Lara, M.J., Pintor, J., 2015b. Diadenosine tetraphosphate induces tight junction disassembly thus increasing corneal epithelial permeability. Br. J. Pharmacol. 172, 1045-1058.

Loma, P., Guzman-Aranguez, A., Perez de Lara, M.J., Pintor, J., 2016. Lactoferrin levels in tears are increased by the topical application of diadenosine tetraphosphate. Curr. Eye Res. 1-3.

Luthje, J., Ogilvie, A., 1983. The presence of diadenosine 5',5" -P1,P3-triphosphate (Ap3A) in human platelets. Biochem. Biophys. Res. Commun. 115, 253-260.

Luthje, J., Ogilvie, A., 1988. Catabolism of Ap4A and Ap3A in whole blood. The dinucleotides are long-lived signal molecules in the blood ending up as intracellular ATP in the erythrocytes. Eur. J. Biochem. 173, 241-245.

Luthje, J., Baringer, J., Ogilvie, A., 1985. Effects of diadenosine triphosphate (Ap3A) and diadenosine tetraphosphate (Ap4A) on platelet aggregation in unfractionated human blood. Blut 51, 405-413.

Mackie, I.A., Seal, D.V., 1984. Diagnostic implications of tear protein profiles. Br. J. Ophthalmol. 68, 321-324. 
Majumdar, S., Tirucherai, G.S., Pal, D., Mitra, A.K., 2003. Functional differences in nucleoside and nucleobase transporters expressed on the rabbit corneal epithelial cell line (SIRC) and isolated rabbit cornea. AAPS PharmSci 5, E15.

Maldonado-Codina, C., Efron, N., 2004. Impact of manufacturing technology and material composition on the clinical performance of hydrogel lenses. Optom. Vis. Sci. Off. Publ. Am. Acad. Optom. 81, 442-454.

Maminishkis, A., Jalickee, S., Blaug, S.A., Rymer, J., Yerxa, B.R., Peterson, W.M., Miller, S.S., 2002. The P2Y(2) receptor agonist INS37217 stimulates RPE fluid transport in vitro and retinal reattachment in rat. Invest.Investig. Ophthalmol. Vis. Sci. 43, 3555-3566.

Mankus, C., Chi, C., Rich, C., Ren, R., Trinkaus-Randall, V., 2012. The P2X(7) receptor regulates proteoglycan expression in the corneal stroma. Mol. Vis. 18, 128-138.

Mantelli, F., Argueso, P., 2008. Functions of ocular surface mucins in health and disease. Curr. Opin. Allergy Clin. Immunol. 8, 477-483.

Martin-Gil, A., Pintor, J., 2010. P2Y2 nucleotide receptors increase the presence of aquaporin-1 in rabbit non pigmented ciliary epithelial cells. Purinergic Signal. 6, S155.

Martin-Gil, A., de Lara, M.J., Crooke, A., Santano, C., Peral, A., Pintor, J., 2012. Silencing of $\mathrm{P} 2 \mathrm{Y}(2)$ receptors reduces intraocular pressure in New Zealand rabbits. Br. J. Pharmacol. 165, 1163-1172.

Mathers, W.D., Lane, J.A., Sutphin, J.E., Zimmerman, M.B., 1996. Model for ocular tear film function. Cornea 15, 110-119.

Matsumoto, Y., Ohashi, Y., Watanabe, H., Tsubota, K., Diquafosol Ophthalmic Solution Phase 2 Study, G, 2012. Efficacy and safety of diquafosol ophthalmic solution in patients with dry eye syndrome: a Japanese phase 2 clinical trial. Ophthalmology 119, 1954-1960.

Mayer, K.L., Nordlund, M.L., Schwartz, G.S., Holland, E.J., 2003. Keratopathy in congenital aniridia. Ocul. Surf. 1, 74-79.

Mayo, C., Ren, R., Rich, C., Stepp, M.A., Trinkaus-Randall, V., 2008. Regulation by P2X7: epithelial migration and stromal organization in the cornea. Invest.Investig. Ophthalmol. Vis. Sci. 49, 4384-4391.

McCann, L.C., Tomlinson, A., Pearce, E.I., Papa, V., 2012. Effectiveness of artificial tears in the management of evaporative dry eye. Cornea 31, 1-5.

McMonnies, C.W., 2015. Inflammation and keratoconus. Optom. Vis. Sci. 92, e35-41.

McNamara, N.A., Fusaro, R.E., Brand, R.J., Polse, K.A., Srinivas, S.P., 1997. Measurement of corneal epithelial permeability to fluorescein. A repeatability study. Investig. Ophthalmol. Vis. Sci. 38, 1830-1839.

McNamara, N.A., Polse, K.A., Brand, R.J., Graham, A.D., Chan, J.S., McKenney, C.D., 1999. Tear mixing under a soft contact lens: effects of lens diameter. Am. J. Ophthalmol. 127, 659-665.

Mediero, A., Peral, A., Pintor, J., 2006. Dual roles of diadenosine polyphosphates in corneal epithelial cell migration. Invest.Investig. Ophthalmol. Vis. Sci. 47, 4500-4506.

Mediero, A., Guzman-Aranguez, A., Crooke, A., Peral, A., Pintor, J., 2008. Corneal reepithelialization stimulated by diadenosine polyphosphates recruits RhoA/ ROCK and ERK1/2 pathways. Invest.Investig. Ophthalmol. Vis. Sci. 49, 4982-4992.

Mediero, A., Alarma-Estrany, P., Pintor, J., 2009. New treatments for ocular hypertension. Auton. Neurosci. 147, 14-19.

Mediero, A., Crooke, A., Guzman-Aranguez, A., Pintor, J., 2011. Phospholipase C/ Protein Kinase $C$ pathway is essential for corneal re-epithelialization induced by Ap(4)A. Curr. Eye Res. 36, 1108-1115.

Merriman-Smith, R., Tunstall, M., Kistler, J., Donaldson, P., Housley, G., Eckert, R., 1998. Expression profiles of P2-receptor isoforms P2Y1 and P2Y2 in the rat lens. Invest.Investig. Ophthalmol. Vis. Sci. 39, 2791-2796.

Meyer, C.H., Hotta, K., Peterson, W.M., Toth, C.A., Jaffe, G.J., 2002. Effect of INS37217, a P2Y(2) receptor agonist, on experimental retinal detachment and electroretinogram in adult rabbits. Invest.Investig. Ophthalmol. Vis. Sci. 43, 3567-3574.

Millar, T.J., Tragoulias, S.T., Anderton, P.J., Ball, M.S., Miano, F., Dennis, G.R., Mudgil, P., 2006. The surface activity of purified ocular mucin at the air-liquid interface and interactions with meibomian lipids. Cornea 25, 91-100.

Miras-Portugal, M.T., Gualix, J., Pintor, J., 1998. The neurotransmitter role of diadenosine polyphosphates. FEBS Lett. 430, 78-82.

Miras-Portugal, M.T., Gualix, J., Mateo, J., Diaz-Hernandez, M., GomezVillafuertes, R., Castro, E., Pintor, J., 1999. Diadenosine polyphosphates, extracellular function and catabolism. Prog. Brain Res. 120, 397-409.

Mitchell, C.H., Carre, D.A., McGlinn, A.M., Stone, R.A., Civan, M.M., 1998. A release mechanism for stored ATP in ocular ciliary epithelial cells. Proc. Natl. Acad. Sci. U. S. A. 95, 7174-7178.

Miyake, G., Ota, I., Miyake, K., Zako, M., Iwaki, M., 2014. Effects of topical diquafosol pretreatment on intraoperative corneal wetting. J. Cataract. Refract Surg. 40, $1682-1688$.

Mizuno, Y., Sasaki, T., 1965. The synthesis of dinucleoside phosphates of natural linkages by the "anhydronucleoside method". Tetrahedron Lett. 4579-4584.

Mori, Y., Nejima, R., Masuda, A., Maruyama, Y., Minami, K., Miyata, K., Amano, S. 2014. Effect of diquafosol tetrasodium eye drop for persistent dry eye after laser in situ keratomileusis. Cornea 33, 659-662.

Moss, S.E., Klein, R., Klein, B.E., 2000. Prevalence of and risk factors for dry eye syndrome. Arch. Ophthalmol. 118, 1264-1268.

Muller, L.J., Marfurt, C.F., Kruse, F., Tervo, T.M., 2003. Corneal nerves: structure, contents and function. Exp. Eye Res. 76, 521-542.

Murakami, T., Fujihara, T., Nakamura, M., Nakata, K., 2000. P2Y(2) receptor stimulation increases tear fluid secretion in rabbits. Curr. Eye Res. 21, 782-787.

Murakami, T., Fujita, H., Fujihara, T., Nakamura, M., Nakata, K., 2002. Novel noninvasive sensitive determination of tear volume changes in normal cats. Ophthalmic Res. 34, 371-374.

Murakami, T., Fujihara, T., Nakamura, M., Nakata, K., 2003. P2Y(2) receptor elicits PAS-positive glycoprotein secretion from rabbit conjunctival goblet cells in vivo. J. Ocul. Pharmacol. Ther. 19, 345-352.

Murakami, T., Fujihara, T., Horibe, Y., Nakamura, M., 2004. Diquafosol elicits increases in net $\mathrm{Cl}$ - transport through $\mathrm{P} 2 \mathrm{Y} 2$ receptor stimulation in rabbit conjunctiva. Ophthalmic Res. 36, 89-93.

Murube, J., 2012. The origin of tears. II. The mucinic component in the XIX and XX centuries. Ocul. Surf. 10, 126-136.

Muscella, A., Greco, S., Elia, M.G., Storelli, C., Marsigliante, S., 2004. Differential signalling of purinoceptors in HeLa cells through the extracellular signalregulated kinase and protein kinase C pathways. J. Cell Physiol. 200, 428-439.

Nagahara, Y., Koh, S., Nishida, K., Watanabe, H., 2015. Prolonged increase in tear meniscus height by 3\% diquafosol ophthalmic solution in eyes with contact lenses. Clin. Ophthalmol. 9, 1029-1031.

Nagase, K., Tomi, M., Tachikawa, M., Hosoya, K., 2006. Functional and molecular characterization of adenosine transport at the rat inner blood-retinal barrier. Biochim. Biophys. Acta 1758, 13-19.

Nakamura, M., Imanaka, T., Sakamoto, A., 2012. Diquafosol ophthalmic solution for dry eye treatment. Adv. Ther. 29, 579-589.

Nam, K.T., Ahn, S.M., Eom, Y., Kim, H.M., Song, J.S., 2015. Immediate effects of 3\% Diquafosol and $0.1 \%$ hyaluronic acid ophthalmic solution on tear break-up time in normal human eyes. J. Ocul. Pharmacol. Ther. 31, 631-635.

Nejima, R., Miyata, K., Tanabe, T., Okamoto, F., Hiraoka, T., Kiuchi, T., Oshika, T., 2005 Corneal barrier function, tear film stability, and corneal sensation after photorefractive keratectomy and laser in situ keratomileusis. Am. J. Ophthalmol. 139, 64-71.

Nichols, J.J., Jones, L., Nelson, J.D., Stapleton, F., Sullivan, D.A., Willcox, M.D., members of the, T.I.W.o.C.L.D, 2013. The TFOS international workshop on contact lens discomfort: introduction. Investig. Ophthalmol. Vis. Sci. 54, 1-6.

Notomi, S., Hisatomi, T., Kanemaru, T., Takeda, A., Ikeda, Y., Enaida, H., Kroemer, G. Ishibashi, T., 2011. Critical involvement of extracellular ATP acting on P2RX7 purinergic receptors in photoreceptor cell death. Am. J. Pathol. 179, 2798-2809.

Nour, M., Quiambao, A.B., Peterson, W.M., Al-Ubaidi, M.R., Naash, M.I., 2003. P2Y(2) receptor agonist INS37217 enhances functional recovery after detachment caused by subretinal injection in normal and rds mice. Invest.Investig. Ophthalmol. Vis. Sci. 44, 4505-4514.

O'Brien, W.J., Taylor, J.L., Brotman, S.J., 1987. Adenosine deaminase in herpes simplex virus induced corneal stromal disease. Curr. Eye Res. 6, 13-18.

Oaknin, S., Rodriguez-Ferrer C.R., Aguilar, J.S., Ramos, A., Rotllan, P. 2001. Receptor binding properties of di (1,N6-ethenoadenosine) 5', 5"'-P1, P4-tetraphosphate and its modulatory effect on extracellular glutamate levels in rat striatum. Neurosci. Lett. 309, 177-180.

Ohtomo, K., Shatos, M.A., Vrouvlianis, J., Li, D., Hodges, R.R., Dartt, D.A., 2011. Increase of intracellular Ca2 + by purinergic receptors in cultured rat lacrima gland myoepithelial cells. Invest.Investig. Ophthalmol. Vis. Sci. 52, 9503-9515.

Ortiz, B., Sillero, A., Gunther Sillero, M.A., 1993. Specific synthesis of adenosine $\left(5^{\prime}\right)$ tetraphospho( $\left.5^{\prime}\right)$ nucleoside and adenosine $\left(5^{\prime}\right)$ oligophospho( $\left.5^{\prime}\right)$ adenosine ( $\mathrm{n}>$ 4) catalyzed by firefly luciferase. Eur. J. Biochem. 212, 263-270.

Panjwani, N., Michalopoulos, G., Song, J., Zaidi, T.S., Yogeeswaran, G., Baum, J., 1990. Neutral glycolipids of migrating and nonmigrating rabbit corneal epithelium in organ and cell culture. Invest.Investig. Ophthalmol. Vis. Sci. 31, 689-695.

Park, D.H., Chung, J.K., Seo, D.R., Lee, S.J., 2015. Clinical effects and safety of 3\% Diquafosol ophthalmic solution for patients with dry eye after cataract surgery: a randomized controlled trial. Am. J. Ophthalmol. 163, 122-131.

Pastor-Anglada, M., Perez-Torras, S., 2015. Nucleoside transporter proteins as biomarkers of drug responsiveness and drug targets. Front. Pharmacol. 6, 13.

Patane, M.A., Cohen, A., From, S., Torkildsen, G., Welch, D., Ousler 3rd, G.W., 2011 Ocular iontophoresis of EGP-437 (dexamethasone phosphate) in dry eye patients: results of a randomized clinical trial. Clin. Ophthalmol. 5, 633-643.

Patel, K., Barnes, A., Camacho, J., Paterson, C., Boughtflower, R., Cousens, D., Marshall, F., 2001. Activity of diadenosine polyphosphates at P2Y receptors stably expressed in 1321N1 cells. Eur. J. Pharmacol. 430, 203-210.

Patel, A.S., Reigada, D., Mitchell, C.H., Bates, S.R., Margulies, S.S., Koval, M., 2005. Paracrine stimulation of surfactant secretion by extracellular ATP in response to mechanical deformation. Am. J. Physiol. Lung Cell Mol. Physiol. 289, L489-L496.

Paulsen, F., 2008. Functional anatomy and immunological interactions of ocula surface and adnexa. Dev. Ophthalmol. 41, 21-35.

Paulsen, A.J., Cruickshanks, K.J., Fischer, M.E., Huang, G.H., Klein, B.E., Klein, R., Dalton, D.S., 2014. Dry eye in the beaver dam offspring study: prevalence, risk factors, and health-related quality of life. Am. J. Ophthalmol. 157, 799-806.

Peral, A., Carracedo, G., Acosta, M.C., Gallar, J., Pintor, J., 2006. Increased levels of diadenosine polyphosphates in dry eye. Invest.Investig. Ophthalmol. Vis. Sci. 47, 4053-4058.

Peral, A., Loma, P., Yerxa, B., Pintor, J., 2008. Topical application of nucleotides increase lysozyme levels in tears. Clin. Ophthalmol. 2, 261-267.

Peral, A., Gallar, J., Pintor, J., 2009. Adenine nucleotide effect on intraocular pressure involvement of the parasympathetic nervous system. Exp. Eye Res. 89, 63-70.

Perez-Santonja, J.J., Sakla, H.F., Cardona, C., Chipont, E., Alio, J.L., 1999. Corneal sensitivity after photorefractive keratectomy and laser in situ keratomileusis for low myopia. Am. J. Ophthalmol. 127, 497-504.

Pérez-Sen, R., Queipo, M.J., Morente, V., Ortega, F., Delicado, E.G., MirasPortugal, M.T., 2015. Neuroprotection Mediated by P2Y13 Nucleotide Receptors in Neurons. Comput. Struct. Biotechnol. J. 13, 160-168. 
Peterson, W.M., Meggyesy, C., Yu, K., Miller, S.S., 1997. Extracellular ATP activates calcium signaling, ion, and fluid transport in retinal pigment epithelium. J. Neurosci. 17, 2324-2337.

Pintor, J., 2005. Adenine nucleotides and dinucleotides as new substances for the treatment of ocular hypertension and glaucoma. Curr. Opin. Investig. Drugs 6, $76-80$.

Pintor, J., 2010. Nucleotides and dinucleotides as natural regulators of intraocular pressure: to see or not to see. Purinergic Signal. 6, S16.

Pintor, J., 2011. Commentary: why are such high concentrations of nucleotides in the lens? Purinergic Signal 7, 169-170.

Pintor, J., Miras-Portugal, M.T., 1995a. A novel receptor for diadenosine polyphosphates coupled to calcium increase in rat midbrain synaptosomes. Br. J. Pharmacol. 115, 895-902.

Pintor, J., Miras-Portugal, M.T., 1995b. P2 purinergic receptors for diadenosine polyphosphates in the nervous system. Gen. Pharmacol. 26, 229-235.

Pintor, J., Miras-Portugal, M.T., 2000. Receptors for diadenosine polyphosphates P2D, P2YApnA, P4 and dinucleotide receptors: are there too many? Trends Pharmacol. Sci. 21, 135-136.

Pintor, J., Torres, M., Miras-Portugal, M.T., 1991. Carbachol induced release of diadenosine polyphosphates-Ap4A and Ap5A-from perfused bovine adrenal medulla and isolated chromaffin cells. Life Sci. 48, 2317-2324.

Pintor, J., Diaz-Rey, M.A., Torres, M., Miras-Portugal, M.T., 1992. Presence of diadenosine polyphosphates-Ap4A and Ap5A-in rat brain synaptic terminals. $\mathrm{Ca} 2+$ dependent release evoked by 4-aminopyridine and veratridine. Neurosci. Lett. 136, 141-144.

Pintor, J., Porras, A., Mora, F., Miras-Portugal, M.T., 1993. Amphetamine-induced release of diadenosine polyphosphates-Ap4A and Ap5A-from caudate putamen of conscious rat. Neurosci. Lett. 150, 13-16.

Pintor, J., King, B.F., Miras-Portugal, M.T., Burnstock, G., 1996. Selectivity and activity of adenine dinucleotides at recombinant P2X2 and P2Y1 purinoceptors. Br. J. Pharmacol. 119, 1006-1012.

Pintor, J., Carracedo, G., Alonso, M.C., Bautista, A., Peral, A., 2002a. Presence of diadenosine polyphosphates in human tears. Pflug. Arch. 443, 432-436.

Pintor, J., Peral, A. Hoyle, C.H., Redick, C., Douglass, J., Sims, I., Yerxa, B., 2002b. Effects of diadenosine polyphosphates on tear secretion in New Zealand white rabbits. J. Pharmacol. Exp. Ther. 300, 291-297.

Pintor, J., Peral, A., Pelaez, T., Martin, S., Hoyle, C.H., 2003. Presence of diadenosine polyphosphates in the aqueous humor: their effect on intraocular pressure. J. Pharmacol. Exp. Ther. 304, 342-348.

Pintor, J., Bautista, A., Carracedo, G., Peral, A., 2004a. UTP and diadenosine tetraphosphate accelerate wound healing in the rabbit cornea. Ophthalmic Physiol Opt. 24, 186-193.

Pintor, J., Sanchez-Nogueiro, J., Irazu, M., Mediero, A., Pelaez, T., Peral, A., 2004b. Immunolocalisation of P2Y receptors in the rat eye. Purinergic Signal 1, 83-90.

Pintor, J., Martin-Gil, A., Fonseca, B., 2011. Activation of TRPV4 induces the release of diadenosine tetraphosphate to the aqueous humour. Investig. Ophthalmol. Vis Sci. 52, 2052.

Puthussery, T. Fletcher, E.L., 2004. Synaptic localization of P2X7 receptors in the rat retina. J. Comp. Neurol. 472, 13-23.

Puthussery, T., Fletcher, E.L., 2007. Neuronal expression of P2X3 purinoceptors in the rat retina. Neuroscience 146, 403-414.

Puthussery, T., Yee, P., Vingrys, A.J., Fletcher, E.L., 2006. Evidence for the involvement of purinergic P2X receptors in outer retinal processing. Eur. J. Neurosci. 24 7-19.

Qasba, P.K., Kumar, S., 1997. Molecular divergence of lysozymes and alpha-lactalbumin. Crit. Rev. Biochem. Mol. Biol. 32, 255-306.

Rabczenko, A., Shugar, D., 1971. Studies on the conformation of nucleosides, dinucleoside monophosphates and homopolynucleotides containing uracil or thymine base residues, and ribose, deoxyribose or 2'-O-methylribose. Acta Biochim. Pol. 18, 387-402.

Ralevic, V., Burnstock, G., 1998. Receptors for purines and pyrimidines. Pharmacol. Rev, 50, 413-492.

Randerath, K., Janeway, C.M., Stephenson, M.L., Zamecnik, P.C., 1966. Isolation an characterization of dinucleoside tetra- and tri-phosphates formed in the presence of lysyl-sRNA synthetase. Biochem. Biophys. Res. Commun. 24, 98-105.

Rapaport, E., Zamecnik, P.C., 1976. Presence of diadenosine 5',5" -P1, P4tetraphosphate $(\mathrm{Ap} 4 \mathrm{~A})$ in mamalian cells in levels varying widely with proliferative activity of the tissue: a possible positive "pleiotypic activator". Proc. Natl. Acad. Sci. U. S. A. 73, 3984-3988.

Rapaport, E., Zamecnik, P.C., Baril, E.F., 1981. HeLa cell DNA polymerase alpha is tightly associated with tryptophanyl-tRNA synthetase and diadenosine $5^{\prime}, 5^{\prime \prime \prime}$ P1,P4-tetraphosphate binding activities. Proc. Natl. Acad. Sci. U. S. A. 78, $838-842$.

Reigada, D., Zhang, X., Crespo, A., Nguyen, J., Liu, J., Pendrak, K., Stone, R.A. Laties, A.M., Mitchell, C., 2006. Stimulation of an alpha1-adrenergic recepto downregulates ecto-5' nucleotidase activity on the apical membrane of RPE cells. Purinergic Signal 2, 499-507.

Rhodes, J.D., Collison, D.J., Duncan, G., 2003. Calcium activates SK channels in the intact human lens. Investig. Ophthalmol. Vis. Sci. 44, 3927-3932.

Ripoll, C., Martin, F., Manuel Rovira, J., Pintor, J., Miras-Portugal, M.T., Soria, B., 1996. Diadenosine polyphosphates. A novel class of glucose-induced intracellular messengers in the pancreatic beta-cell. Diabetes 45, 1431-1434.

Roberts, J.A., Vial, C., Digby, H.R., Agboh, K.C., Wen, H., Atterbury-Thomas, A., Evans, R.J., 2006. Molecular properties of P2X receptors. Pflug. Arch. 452, $486-500$.
Rodriguez del Castillo, A., Torres, M., Delicado, E.G., Miras-Portugal, M.T., 1988. Subcellular distribution studies of diadenosine polyphosphates-Ap4A and Ap5A-in bovine adrenal medulla: presence in chromaffin granules. J. Neurochem. 51, 1696-1703.

Romero-Jimenez, M., Santodomingo-Rubido, J., Wolffsohn, J.S., 2010. Keratoconus: a review. Cont. Lens Anterior Eye 33, 157-166.

Ross, F.M., Brodie, M.J., Stone, T.W., 1999. Nucleotide and dinucleotide effects on rates of paroxysmal depolarising bursts in rat hippocampus. Prog. Brain Res. $120,251-262$.

Samways, D.S., Li, Z., Egan, T.M., 2014. Principles and properties of ion flow in P2X receptors. Front. Cell. Neurosci. 8, 6 .

Sanderson, J., Dartt, D.A., Trinkaus-Randall, V., Pintor, J., Civan, M.M., Delamere, N.A. Fletcher, E.L., Salt, T.E., Grosche, A., Mitchell, C.H., 2014. Purines in the eye: recent evidence for the physiological and pathological role of purines in the RPE, retinal neurons, astrocytes, Muller cells, lens, trabecular meshwork, cornea and lacrimal gland. Exp. Eye Res. 127, 270-279.

Santagati, M.G., La Terra Mule, S., Amico, C., Pistone, M., Rusciano, D., Enea, V., 2005. Lactoferrin expression by bovine ocular surface epithelia: a primary cell culture model to study lactoferrin gene promoter activity. Ophthalmic Res. 37, 270-278.

Sauer, H., Hescheler, J., Wartenberg, M., 2000. Mechanical strain-induced $\mathrm{Ca}(2+)$ waves are propagated via ATP release and purinergic receptor activation. Am. J. Physiol. Cell Physiol. 279, C295-C307.

Saul, A., Hausmann, R., Kless, A., Nicke, A., 2013. Heteromeric assembly of P2X subunits. Front. Cell. Neurosci. 7, 250.

Schachter, J.B., Li, Q., Boyer, J.L., Nicholas, R.A., Harden, T.K., 1996. Second messenger cascade specificity and pharmacological selectivity of the human P2Y1purinoceptor. Br. J. Pharmacol. 118, 167-173.

Schaumberg, D.A., Sullivan, D.A., Buring, J.E., Dana, M.R., 2003. Prevalence of dry eye syndrome among US women. Am. J. Ophthalmol. 136, 318-326.

Schaumberg, D.A., Dana, R., Buring, J.E., Sullivan, D.A., 2009. Prevalence of dry eye disease among US men: estimates from the physicians' health studies. Arch. Ophthalmol. 127, 763-768.

Schein, O.D., Munoz, B, Tielsch, J.M., Bandeen-Roche, K., West, S, 1997. Prevalence of dry eye among the elderly. Am. J. Ophthalmol. 124, 723-728.

Schrader, A.M., Camden, J.M., Weisman, G.A., 2005. P2Y2 nucleotide receptor upregulation in submandibular gland cells from the NOD.B10 mouse model of Sjogren's syndrome. Arch. Oral Biol. 50, 533-540.

Sen, R.P., Delicado, E.G., Castro, E., Miras-Portugal, M.T., 1993. Effect of P2Y agonists on adenosine transport in cultured chromaffin cells. J. Neurochem. 60, 613-619.

Shahidullah, M., Mandal, A., Beimgraben, C., Delamere, N.A., 2012a. Hyposmotic stress causes ATP release and stimulates $\mathrm{Na}, \mathrm{K}-\mathrm{ATP}$ ase activity in porcine lens. J. Cell. Physiol. 227, 1428-1437.

Shahidullah, M., Mandal, A., Delamere, N.A., 2012b. TRPV4 in porcine lens epithelium regulates hemichannel-mediated ATP release and Na-K-ATPase activity. Am. J. Physiol. Cell Physiol. 302, C1751-C1761.

Shigematsu, Y., Shimoda, Y., Kaneda, M., 2007. Distribution of immunoreactivity for P2X3, P2X5, and P2X6-purinoceptors in mouse retina. J. Mol. Histol. 38, 369-371.

Shigeyasu, C., Hirano, S., Akune, Y., Yamada, M., 2015a. Diquafosol tetrasodium increases the concentration of Mucin-like substances in tears of healthy human subjects. Curr. Eye Res. 40, 878-883.

Shigeyasu, C., Yamada, M., Akune, Y., Tsubota, K., 2015b. Diquafosol sodium ophthalmic solution for the treatment of dry eye: clinical evaluation and biochemical analysis of tear composition. Jpn. J. Ophthalmol. 59 (6), 415-420.

Sosnova-Netukova, M., Kuchynka, P., Forrester, J.V., 2007. The suprabasal layer of corneal epithelial cells represents the major barrier site to the passive movement of small molecules and trafficking leukocytes. Br. J. Ophthalmol. 91, $372-378$.

Soto, D., Pintor, J., Peral, A., Gual, A., Gasull, X., 2005. Effects of dinucleoside polyphosphates on trabecular meshwork cells and aqueous humor outflow facility. J. Pharmacol. Exp. Ther. 314, 1042-1051.

Srinivas, S.P., Mutharasan, R., Fleiszig, S., 2002. Shear-induced ATP release by cultured rabbit corneal epithelial cells. Adv. Exp. Med. Biol. 506, 677-685.

Srinivasan, S., Slomovic, A.R., 2007. Sjogren syndrome. Compr. Ophthalmol. Update 8, 205-212.

Stefan, C., Gijsbers, R., Stalmans, W., Bollen, M., 1999. Differential regulation of the expression of nucleotide pyrophosphatases/phosphodiesterases in rat liver. Biochim. Biophys. Acta 1450, 45-52.

Sugioka, M., Zhou, W.L., Hofmann, H.D., Yamashita, M., 1999. Involvement of P2 purinoceptors in the regulation of DNA synthesis in the neural retina of chick embryo. Int. J. Dev, Neurosci. 17, 135-144.

Sugiyama, T., Oku, H., Komori, A., Ikeda, T., 2006. Effect of P2X7 receptor activation on the retinal blood velocity of diabetic rabbits. Arch. Ophthalmol. 124, 1143-1149.

Sullivan, D.M., Erb, L., Anglade, E., Weisman, G.A., Turner, JT., Csaky, K.G., 1997. Identification and characterization of P2Y2 nucleotide receptors in human retinal pigment epithelial cells. J. Neurosci. Res. 49, 43-52.

Suzuki, K., Saito, J., Yanai, R., Yamada, N., Chikama, T., Seki, K., Nishida, T., 2003. Cellmatrix and cell-cell interactions during corneal epithelial wound healing. Prog. Retin Eye Res. 22, 113-133.

Szwergold, B.S., Lal, S., 2005. Identification of diadenosine-triphosphate in mature bovine lenses. Biochem. Biophys. Res. Commun. 326, 718-723.

Takamura, E., Tsubota, K., Watanabe, H., Ohashi, Y., Diquafosol Ophthalmic Solution Phase 3 Study, G, 2012. A randomised, double-masked comparison study of 
diquafosol versus sodium hyaluronate ophthalmic solutions in dry eye patients. Br. J. Ophthalmol. 96, 1310-1315.

Takizawa, T., 1998. 5'-nucleotidase in rat photoreceptor cells and pigment epithelial cells processed by rapid-freezing enzyme cytochemistry. J. Histochem Cytochem 46, 1091-1095.

Tanioka, H., Kuriki, Y., Sakamoto, A., Katsuta, O., Kawazu, K., Nakamura, M., 2014. Expression of the $\mathrm{P} 2 \mathrm{Y}(2)$ receptor on the rat ocular surface during a 1-year rearing period. Jpn. J. Ophthalmol. 58, 515-521.

Tauber, J., Davitt, W.F., Bokosky, J.E., Nichols, K.K., Yerxa, B.R., Schaberg, A.E., LaVange, L.M., Mills-Wilson, M.C., Kellerman, D.J., 2004. Double-masked, placebo-controlled safety and efficacy trial of diquafosol tetrasodium (INS365) ophthalmic solution for the treatment of dry eye. Cornea 23, 784-792.

Terakado, K., Yogo, T., Kohara, Y., Soeta, S., Nezu, Y., Harada, Y., Hara, Y., Amasaki, H., Tagawa, M., 2014. Conjunctival expression of the P2Y2 receptor and the effects of 3\% diquafosol ophthalmic solution in dogs. Vet. J. 202, 48-52.

Toda, I., 2008. LASIK and the ocular surface. Cornea 27 (Suppl. 1), S70-S76.

Tragoulias, S.T., Anderton, P.J., Dennis, G.R., Miano, F., Millar, T.J., 2005. Surface pressure measurements of human tears and individual tear film components indicate that proteins are major contributors to the surface pressure. Cornea 24, 189-200.

Ts'o, P.O., Kondo, N.S., Schweizer, M.P., Hollis, D.P., 1969. Studies of the conformation and interaction in dinucleoside mono- and diphosphates by proton magnetic resonance. Biochemistry 8, 997-1029.

Uusitalo, R.J., Aine, E., Sen, N.H., Laatikainen, L., 2002. Implantable contact lens for high myopia. J. Cataract. Refract Surg. 28, 29-36.

Valverde, M.A., Diaz, M., Sepulveda, F.V., Gill, D.R., Hyde, S.C., Higgins, C.F., 1992. Volume-regulated chloride channels associated with the human multidrugresistance P-glycoprotein. Nature 355, 830-833.

van Bijsterveld, O.P., 1969. Diagnostic tests in the Sicca syndrome. Arch. Ophthalmol, 82, 10-14.

van der Worp, E., Bornman, D., Ferreira, D.L., Faria-Ribeiro, M., Garcia-Porta, N., Gonzalez-Meijome, J.M., 2014. Modern scleral contact lenses: a review. Cont. Lens Anterior Eye 37, 240-250.

Varshavsky, A., 1983. Diadenosine 5', 5'"'-P1, P4-tetraphosphate: a pleiotropically acting alarmone? Cell 34, 711-712.

Vessey, K.A., Fletcher, E.L., 2012. Rod and cone pathway signalling is altered in the P2X7 receptor knock out mouse. PLoS One 7, e29990.

Viso, E., Rodriguez-Ares, M.T., Gude, F., 2009. Prevalence of and associated factors for dry eye in a Spanish adult population (the Salnes Eye Study). Ophthalmic Epidemiol. 16, 15-21.

Vollmayer, P., Clair, T., Goding, J.W., Sano, K., Servos, J., Zimmermann, H., 2003. Hydrolysis of diadenosine polyphosphates by nucleotide pyrophosphatases/ phosphodiesterases. Eur. J. Biochem. 270, 2971-2978.

von Kugelgen, I., 2006. Pharmacological profiles of cloned mammalian P2Y-receptor subtypes. Pharmacol. Ther. 110, 415-432.

von Kugelgen, I., Harden, T.K., 2011. Molecular pharmacology, physiology, and structure of the P2Y receptors. Adv. Pharmacol. 61, 373-415.

von Kugelgen, I., Hoffmann, K., 2015. Pharmacology and structure of P2Y receptors. Neuropharmacology 104, 50-61.

Wang, Y., Chang, C.F., Morales, M., Chiang, Y.H., Harvey, B.K., Su, T.P., Tsao, L.I., Chen, S., Thiemermann, C., 2003. Diadenosine tetraphosphate protects against injuries induced by ischemia and 6-hydroxydopamine in rat brain. J. Neurosci. 23, 7958-7965.

Ward, M.M., Puthussery, T., Fletcher, E.L., 2008. Localization and possible function of P2Y(4) receptors in the rodent retina. Neuroscience 155, 1262-1274.

Warner, A.H., 1964. Isolation, purification, and some properties of P1,P4Diguanosine 5'-Tetraphosphate asymmetrical-pyrophosphohydrolase from Brine Shrimp Eggs. Ornl-3682. ORINS Rep. U. S. A. T. Energy Comm. 126, 1-31.

Warshaw, M.M., Tinoco Jr., I., 1965. Absorption and optical rotatory dispersion of six dinucleoside phosphates. J. Mol. Biol. 13, 54-64.

Weinger, I., Klepeis, V.E., Trinkaus-Randall, V., 2005. Tri-nucleotide receptors play a critical role in epithelial cell wound repair. Purinergic Signal 1, 281-292.

Wheeler-Schilling, T.H., Marquordt, K., Kohler, K., Jabs, R., Guenther, E., 2000. Expression of purinergic receptors in bipolar cells of the rat retina. Brain Res. Mol. Brain Res. 76, 415-418.

Wheeler-Schilling, T.H., Marquordt, K., Kohler, K., Guenther, E., Jabs, R., 2001.
Identification of purinergic receptors in retinal ganglion cells. Brain Res. Mol. Brain Res. 92, 177-180.

Wildman, S.S., Brown, S.G., King, B.F., Burnstock, G., 1999. Selectivity of diadenosine polyphosphates for rat P2X receptor subunits. Eur. J. Pharmacol. 367, 119-123.

Wolffsohn, J.S., Drew, T., Dhallu, S., Sheppard, A., Hofmann, G.J., Prince, M., 2013. Impact of soft contact lens edge design and midperipheral lens shape on the epithelium and its indentation with lens mobility. Invest.Investig. Ophthalmol. Vis. Sci. 54, 6190-6197.

Wu, D., Chen, W.Q., Li, R., Wang, Y., 2015. Efficacy and safety of topical diquafosol ophthalmic solution for treatment of dry eye: a systematic review of randomized clinical trials. Cornea 34, 644-650.

Wurm, A., Lipp, S., Pannicke, T., Linnertz, R., Krugel, U., Schulz, A., Farber, K., Zahn, D. Grosse, J., Wiedemann, P., Chen, J., Schoneberg, T., Illes, P., Reichenbach, A. Bringmann, A., 2010. Endogenous purinergic signaling is required for osmotic volume regulation of retinal glial cells. J. Neurochem. 112, 1261-1272.

Xie, Z., Miller, G.M., 2009. A receptor mechanism for methamphetamine action in dopamine transporter regulation in brain. J. Pharmacol. Exp. Ther. 330, $316-325$.

Yamaguchi, M., Nishijima, T., Shimazaki, J., Takamura, E., Yokoi, N., Watanabe, H. Ohashi, Y., 2014. Clinical usefulness of diquafosol for real-world dry eye patients: a prospective, open-label, non-interventional, observational study. Adv. Ther. 31, 1169-1181.

Yamaguchi, M., Nishijima, T., Shimazaki, J., Takamura, E., Yokoi, N., Watanabe, H., Ohashi, Y., 2015. Real-world assessment of diquafosol in dry eye patients with risk factors such as contact lens, meibomian gland dysfunction, and conjunctivochalasis: subgroup analysis from a prospective observational study. Clin. Ophthalmol. 9, 2251-2256.

Yenice, O., Onal, S., Midi, I., Ozcan, E., Temel, A., I-Gunal, D., 2008. Visual field analysis in patients with Parkinson's disease. Park. Relat. Disord. 14, 193-198.

Yerxa, B.R., Douglass, J.G., Elena, P.P., Caillaud, T., Amar, T., Edick, C., Peterson, W.M., 2002a. Potency and duration of action of synthetic P2Y2 receptor agonists on Schirmer scores in rabbits. Adv. Exp. Med. Biol. 506, 261-265.

Yerxa, B.R., Sabater, J.R., Davis, C.W., Stutts, M.J., Lang-Furr, M., Picher, M., Jones, A.C., Cowlen, M., Dougherty, R., Boyer, J., Abraham, W.M., Boucher, R.C., 2002b. Pharmacology of INS37217 [P(1)-(uridine $\left.5^{\prime}\right)-\mathrm{P}(4)-\left(2^{\prime}\right.$-deoxycytidine $\left.5^{\prime}\right)$ tetraphosphate, tetrasodium salt], a next-generation P2Y(2) receptor agonist for the treatment of cystic fibrosis. J. Pharmacol. Exp. Ther. 302, 871-880.

Yokoi, N., Kinoshita, S., 1995. Clinical evaluation of corneal epithelial barrier function with the slit-lamp fluorophotometer. Cornea 14, 485-489.

Yokoi, N., Kato, H., Kinoshita, S., 2014. Facilitation of tear fluid secretion by $3 \%$ diquafosol ophthalmic solution in normal human eyes. Am. J. Ophthalmol. 157, 85-92.

Yokoi, N., Sonomura, Y., Kato, H., Komuro, A., Kinoshita, S., 2015. Three percent diquafosol ophthalmic solution as an additional therapy to existing artificial tears with steroids for dry-eye patients with Sjogren's syndrome. Eye (Lond.) 29, 1204-1212.

Yoshida, Y., Ban, Y., Kinoshita, S., 2009. Tight junction transmembrane protein claudin subtype expression and distribution in human corneal and conjunctival epithelium. Invest.Investig. Ophthalmol. Vis. Sci. 50, 2103-2108.

Zamecnik, P.C., Stephenson, M.L., Janeway, C.M., Randerath, K., 1966. Enzymatic synthesis of diadenosine tetraphosphate and diadenosine triphosphate with a purified lysyl-sRNA synthetase. Biochem. Biophys. Res. Commun. 24, 91-97.

Zamecnik, P.C., Rapaport, E., Baril, E.F., 1982. Priming of DNA synthesis by diadenosine $5^{\prime}, 5^{\prime \prime \prime}$-P1,P4-tetraphosphate with a double-stranded octadecamer as a template and DNA polymerase alpha. Proc. Natl. Acad. Sci. U. S. A. 79, $1791-1794$

Zimmermann, H., 1999. Two novel families of ectonucleotidases: molecular structures, catalytic properties and a search for function. Trends Pharmacol. Sci. 20, $231-236$.

Zimmermann, H., 2000. Extracellular metabolism of ATP and other nucleotides. Naunyn Schmiedeb. Arch. Pharmacol. 362, 299-309.

Zimmermann, H., Zebisch, M., Strater, N., 2012. Cellular function and molecular structure of ecto-nucleotidases. Purinergic Signal 8, 437-502.

Zmijewski, M.A., Sweatman, T.W., Slominski, A.T., 2009. The melatonin-producing system is fully functional in retinal pigment epithelium (ARPE-19). Mol. Cell Endocrinol. 307, 211-216. 